\title{
Who do Unions Target?
}

\section{Unionization over the Life-Cycle of U.S. Businesses*}

\author{
Emin Dinlersoz $^{\dagger} \quad$ Jeremy Greenwood Henry Hyatt $^{\ddagger}$
}

December 2013

\begin{abstract}
What type of businesses do unions target for organizing and when? A dynamic model of the union organizing process is constructed to answer this question. A union monitors establishments in an industry to learn about their productivity, and decides which ones to organize and when. The predictions of the model find support in union certification elections data for 1977-2007 matched with data on establishment characteristics. Two selection effects emerge: unions target larger and more productive establishments early in their life-cycles, and, conditional on targeting, unions are more likely to win elections in smaller and less productive establishments.

JEL Codes: J5, J50, J51, L11, L23, L25, L6, D24, D21.

Key Words: Unionization, Union Organizing, Union Certification Election, Diffusion of Unionization, Bayesian Learning, Productivity.
\end{abstract}

\footnotetext{
*Any opinions and conclusions expressed herein are those of the authors and do not necessarily represent the views of the U.S. Census Bureau. All results have been reviewed to ensure that no confidential information is disclosed.

$\dagger$ Corresponding author. Center for Economic Studies, U.S. Census Bureau, 4600 Silver Hill Road, Suitland, MD 20746. Tel: (301) 763 7889, Fax: (301) 763 5935, E-mail: emin.m.dinlersoz@census.gov

${ }^{\ddagger}$ Department of Economics, University of Pennsylvania, 3718 Locust Walk, Philadelphia, PA, 19104-6297.

${ }^{\S}$ Center for Economic Studies, U.S. Census Bureau, 4600 Silver Hill Road, Suitland, MD 20746. E-mail: henry.r.hyatt@census.gov
} 


\section{Introduction}

Unions have been influential in the U.S. economy and politics for much of the 20th century. They continue to be so even though the private sector unionization has declined persistently over the last four decades. ${ }^{1}$ Despite the long tradition of union activity in the U.S., little is known about the dynamics of union organizing and the diffusion of unionization across businesses in an industry. Whom do unions target? Do they typically target large and productive business establishments that can provide larger membership and benefits to the union? Such establishments may be harder to organize because they can provide better working conditions, higher wages, and have greater resources and better management to resist unionization. Alternatively, do they target establishments that are easier to organize because of poor labor conditions and weak management, which may also be correlated with low productivity? When in an establishment's life-cycle does a union try to organize it? A lack of comprehensive panel data on establishment-level union activity in the U.S. has precluded definitive answers to these questions. The few empirical studies on aspects of the unionization process usually focus on newly certified establishments in datasets that include unions alone, with little information on the establishment side. ${ }^{2}$ The basic establishment-level dynamics of union activity have remained largely undocumented and unexplored.

This paper assesses the relationship between establishment characteristics and union activity for the period 1977-2007 by combining the entire National Labor Relations Board (NLRB) union election data with the data for the universe of establishments in the private sector from the U.S. Census Bureau. Using this newly constructed dataset, the nature of three decades of union organizing activity in the U.S. is analyzed. This longitudinally-linked establishment level dataset makes it possible to relate establishment characteristics, such as size, age, and productivity, to union activity over the life-cycle of an establishment in the form of certification and decertification elections, and to the outcomes of these elections.

The data is analyzed from the perspective of a dynamic model of union organizing. The model highlights union learning about an establishment's productivity as a potential mechanism

\footnotetext{
${ }^{1}$ In 2012 , only $6.6 \%$ of private sector workers in the U.S. were union members, compared to $24.2 \%$ in $1973-$ see the Union Membership and Coverage Database at www.unionstats.com and the associated documentation in Hirsch and MacPherson (2003).

${ }^{2}$ See, e.g., Voos (1984), Farber and Western (2001), Holmes (2006), and Ferguson (2008).
} 
in determining the type of production units that are targeted by unions and the timing of unionization. The unionization process is modeled in a variant of Jovanovic's (1982) model of industry dynamics. An establishment enters the industry with a prior about its unknown underlying productivity. After entry, each establishment experiences random shocks to its productivity over time. More productive establishments tend to be larger, and generate higher profits. There is also a union in the industry, whose aim is to maximize its life-time utility from organizing labor. It monitors establishments in an effort to learn about their productivity in a Bayesian fashion over time. Suppose that unionization is a costly and virtually irreversible process. Which establishments in the industry should the union organize and when?

The model predicts that unions target large and productive establishments early on in their life-cycles. Among establishments of a given age, larger and more productive ones are more likely to be targeted. For any given size or productivity, younger establishments are more likely to experience a certification election, and the likelihood of an establishment being targeted for the first time by a union declines with age. Similar predictions apply to the likelihood of the event that an establishment is organized by a union successfully for the first time - successful organizing occurs when a union targets an establishment for organizing and wins the certification election. Furthermore, the probability of union win in a certification election conditional on an establishment being targeted for organizing is lower in larger and more productive establishments. The model also suggests that in a cross section of establishments unionized ones are on average larger, older, and more productive than the rest.

The predictions of the model are taken to data on union activity in the entire set of U.S. private sector establishments born between 1977 and 2007. ${ }^{3}$ During this period, the number of new union certification elections in a year declined from around 9,000 in 1977 to about 2, 000 in 2007. About $0.03 \%$ of all establishments born during this period were targeted for the first time by a union for potential organizing. Unions tended to win around $47 \%$ of certification elections in a year, on average, throughout this period, though the win rate increased from about $50 \%$ to nearly $60 \%$ between 2000 and 2007. Given that unions won on average about half of the

\footnotetext{
${ }^{3}$ In the U.S., union certification elections occur mainly in occupational groups at the establishment level. The empirical work focuses on establishments as the unit of analysis, as the theoretical model considers the first time a union targets an establishment and wins an election, regardless of the occupational group that is the subject of the organizing.
} 
certification elections, the likelihood of a union successfully organizing an establishment for the first time was only around $0.015 \%$. As of 2007 , about $0.2 \%$ of all establishments born between 1977 and 2007 were still unionized.

Based on the model, four probabilities of interest are explored: the probability of an establishment being targeted by a union the first time, the probability of union win in the first ever certification election in an establishment, the probability that a union successfully organizes an establishment the first time, and the probability that a randomly selected establishment is unionized. Based on the model's implications, each of these probabilities are modeled using a logit specification, where the probabilities are related to establishment size, productivity, age, and other controls. The data supports the model's predictions that unions target large and productive establishments. The likelihood of an establishment with more than 500 employees being targeted by a union is about 10 times more likely to be targeted compared to an establishment with less than 10 employees. Furthermore, unions do not wait too long to target a large and productive establishment after it is born. Conditional on size or productivity, the likelihood of an establishment being targeted by a union for the first time is highest around the time of its birth, and declines steadily until about 10 to 12 years after entry, remaining relatively flat thereafter. For the entire private sector, the youngest group of establishments (0-3 years old) are about 1.76 times more likely to be targeted compared with the oldest group $(25+$ years old $)$.

Within the set of establishments that are targeted, unions are less likely to win certification elections in larger and more productive units, as the model suggests. The probability of a union win in a certification election declines as establishment size increases. The probability of win is about $31 \%$ in the largest employment category (500+ employees), and about $58 \%$ in the smallest category (1-9 employees). The negative effect of establishment size on union win likelihood does not overwhelm the effect that unions target larger, more productive establishments for an election. As a result, successful union organizing is more likely to occur in larger and more productive establishments. Establishments in the largest employment category are 12 times more likely to be successfully organized by a union compared with the smallest category. Moreover, at any point in time, union establishments are more productive, larger, and older compared with non-union ones, as predicted by the model. Establishments in the largest employment class are about 11 times more likely to be unionized, compared with the ones in 
the smallest one. In general, size effects tend to be much stronger than productivity effects. All effects appear to be more pronounced in manufacturing sector than in the entire private sector.

Certain other characteristics of establishments that are observable by unions are also significantly associated with the likelihood of being targeted. For instance, being part of a multi-unit firm, having at least one sister establishment that is already unionized, and being located in a state that does not have a right-to-work law increase the likelihood of being targeted by a union. These effects also give support to the hypothesized learning process behind unionization, as unions can use all of these additional signals to learn more about the eligibility of an establishment for successful organizing. In practice, unions indeed seem to rely on all such signals. For instance, Figure 1 shows the information solicited by the United Automobile Workers (UAW) union in online petitions for union organizing by workers in an establishment. In addition to requesting a "best estimate" of the establishment's total employment, the UAW is interested in obtaining information on the identity of the parent firm, whether the firm has multiple establishments, and the union status of other establishments within the same firm.

There is a large body of literature on the effects of unionization on firm-level outcomes such as employment, wages, productivity, exit, stock market value, and others. ${ }^{4}$ Many of these studies do not usually consider the process by which establishments are chosen for union organizing. Most studies follow relatively small samples of large businesses or publicly traded businesses that survive over a narrow window of time before and after unionization. With some exceptions, these studies are therefore subject to a combination of survival, union selection, size, and public-status bias. This study avoids such biases by focusing on the entire set of establishments in the U.S., and by following the establishments from their birth onwards, not just over a period before and after unionization. Establishments targeted and successfully organized by unions are found to differ systematically from the non-targeted. This selection bias needs to be taken into account in assessing the effects of unionization. To the extent that post-unionization outcomes depend on the establishment characteristics that prevail at the time of unionization and persist into future, the selection based on characteristics, such as size, productivity and age, is important.

Two distinct selection effects emerge. The first is the selection of larger and more productive establishments by unions as targets for organizing. The second pertains to the result of a

\footnotetext{
${ }^{4}$ See, e.g., Freeman and Medoff (1984) for a comprehensive discussion of such studies.
} 
certification election. In establishments that experience a certification election for the first time in their life-cycle, unions are more likely to win the election among smaller and less productive ones. Such establishments may be inherently prone to losing a certification election due to a lack of good management and organizational practices which may also be associated with low productivity and fewer resources to resist unionization. ${ }^{5}$ This second selection effect is dominated by the first. As a result, unions are more likely to successfully organize establishments that are on average larger and more productive than others.

The age effects found in this study offer further insight to the unionization process. Conditional on observable characteristics, establishments are most likely to experience their first certification election and a union victory within the first couple of years after their entry. The likelihood of an establishment being targeted by a union and a subsequent union victory taper off as new establishments age. While this pattern is consistent with the learning model proposed here, there may be alternative explanations, such as lack of managerial experience with union organizing tactics in young businesses. The age effects also suggest a cautionary note for future efforts in using NLRB union certification election data in conjunction with establishment level data. Sample selection techniques used in many prior studies often de-emphasize or exclude from analysis establishments that did not exist prior to the election, or those young establishments that existed only a few years before the election. Such establishments are precisely the ones most likely to experience a certification election.

The concentration of unions in large and productive establishments re-opens the question of whether unions have discernible effects on sectors of the economy where they are more prevalent. In general, unions may have adverse effects on establishment productivity and output, and they may also influence the type of technologies that are implemented in establishments. ${ }^{6}$ These effects may take time to materialize. If unions target more productive and larger establishments, the welfare costs may be higher than the ones traditionally estimated by Rees (1963), which arise solely from high union wages. ${ }^{7}$ Recent work also argues that unions played an important

\footnotetext{
${ }^{5}$ Dinardo and Lee (2004) also mention these two potential selection effects in union organizing. They do not study the unionization process, but rather the effects of unionization on outcomes such as wages and exit likelihood. Their approach in addressing the two selectivity biases is to look at cases where unions barely won certifications elections versus cases where they barely lost. Frandsen (2013) follows a similar approach.

${ }^{6}$ See, e.g., Schmitz (2005).

${ }^{7}$ Additionally, just the threat of unionization may effect a firm's behavior, as Taschereau-Dumouchel (2012)
} 
role in the decline of manufacturing in the U.S. Rust Belt. ${ }^{8}$ This role may be more emphasized when unions are concentrated in larger and more productive manufacturing plants. If adverse effects of unions on businesses are wide-spread, unions' concentration in large and productive plants may have accelerated the general decline of manufacturing in U.S. since the 1970's under increased competition and foreign trade. Conversely, the decline of manufacturing due to competitive pressure, trade, and technological change, which led to the disappearance of large and productive manufacturing plants that unions tend to target, may have reinforced the decline of unions by depriving them of lucrative organizing opportunities. Holmes (2011) provides evidence on the decline of large manufacturing plants in the U.S. Even if unions are able to extract rents from businesses, the finding that unionized businesses tend to be larger and more productive implies that unions may not have a large effect on business performance or survival. For example, Dinardo and Lee (2004) find little effect of unions on wages, employment, and survival in relatively large manufacturing establishments, a result that may be driven by the selection effects documented here. These establishments may be able to withstand any adverse effects of unions. Smaller, less productive establishments, however, may experience larger effects. Future work can assess this potentially heterogeneous impact of unionization on establishment-level outcomes in light of the findings here.

The findings also provide guidance on the modeling of the unionization process and the diffusion of unionization in a population of heterogeneous firms. Models that recognize the selection of unions into larger and more productive businesses are rare. For instance, Dinlersoz and Greenwood (2013) posit a framework where unions organize the most productive (and largest) firms because such firms are able to afford both higher employment and higher wages for union members. Other studies that aim to model unions as integral parts of the economy can also benefit from the empirical regularities pertaining to the unionization process provided in this paper. The union learning process analyzed in the model can be also generalized to include learning from organizing other establishments in an industry, and learning from other unionized establishments in the same geographic area, as emphasized by Holmes (2006).

The rest of the paper is organized as follows. The next section presents the model and argues. To prevent unionization, firms may have to offer high wages and better benefits than in a world without the threat of unionization.

${ }^{8}$ See Alder, Lagakos, and Ohanian (2013). 
derives its testable implications. Section 3 describes empirical methodology, followed by the description of the data in Section 4. Section 5 presents the findings. Section 6 makes concluding remarks.

\section{A Model of Union Learning and Organizing}

Consider an infinitely-lived economy inhabited by establishments that differ in total factor productivity. Profits and any measure of size (e.g. employment, output, or revenue) for an establishment are increasing functions of its productivity. Without loss of generality, assume that there is a single union whose aim is to organize the establishments, each one separately. ${ }^{9}$ The union's benefit from organizing an establishment is taken to be a time-invariant function of the establishment's productivity. Establishments draw their productivity from a stationary distribution, implying that the union targeting decision does not depend on calendar time. Each establishment is born non-unionized, but can become unionized as early as during its first period. For simplicity, unionization is an irreversible event, and each establishment can become unionized only once. ${ }^{10}$

Neither the union nor an establishment knows the establishment's underlying productivity, but have prior beliefs on its distribution. Both parties update their priors over time as they obtain more information about the productivity. For simplicity, they observe the same information every period, and their learning processes are identical. ${ }^{11}$ Based on the learning process, the union decides whether and when to target an establishment for organizing. As in MacDonald and Robinson (1992), there is a cost of organizing. This cost limits the number and type of establishments that the union targets, and hence, the diffusion of unionization in the industry. ${ }^{12}$

\footnotetext{
${ }^{9}$ The main implications of the model do not change significantly if there are multiple unions each of which can target establishments independently, or if a union targets several establishments at once.

${ }^{10}$ Once it is certified in an establishment, the decertification of a union is very rare. Only about $1 \%$ of unionized establishments experience a decertification election. The most common way for a union to dissolve at an establishment is through establishment exit. Furthermore, multiple certification elections in an establishment are rare (less than $5 \%$ of establishments experience multiple elections).

${ }^{11}$ It is possible to let the union and establishment observe different signals of profitability and have different learning processes. Such asymmetry is not the focus of the paper.

${ }^{12}$ Union organizing costs may include costs associated with monitoring an establishment's performance, pene-
} 
The timing of events and decisions for the union within a period is shown in Figure 2. Time is discrete. The union enters a period with prior beliefs about the productivity of each establishment and with the knowledge of the cost of organizing the establishment and the likelihood of winning the certification election. At the beginning of the period, the union decides which establishments to target before establishments realize their current period productivity. Certification elections are then held. The outcome of a certification election is a random event. Unionization occurs when the union wins the election. The current period productivity of each establishment is then observed, and the production takes place. At this time, the union realizes the benefits for the establishment's employees. At the end of the period, the union and each establishment update their beliefs about the latter's long-run productivity, and the next period's cost of organizing for each non-unionized establishment is revealed.

\subsection{The Productivity Process}

Let $x_{a}$ denote (the logarithm of) total factor productivity for an age- $a$ establishment. For $a \geq 1$, the variable $x_{a}$ follows the process [see Jovanovic (1982)]

$$
x_{a}=\chi+\varepsilon_{a},
$$

where $\varepsilon_{a} \sim N\left(0, \sigma_{\varepsilon}^{2}\right)$ is white noise. Both $\chi$ and $\varepsilon_{a}$ are unknown by the union and establishment. The distribution for $\varepsilon_{a}$ is known.

Just after an establishment's entry, $\chi$ and $\varepsilon_{1}$ are drawn. The parameter $\chi$ comes from the distribution $N\left(\bar{\chi}, \sigma_{\chi}^{2}\right)$, and it is fixed for the rest of the establishment's life. While the establishment does not know $\chi$, it knows its distribution. Upon drawing $\varepsilon_{1}$ and $\chi$, the establishment learns $x_{1}$. It can start first-period production then. Thereafter, the establishment's $x_{a}$ fluctuates around its average, $\chi$. Both the establishment and the union learn about $\chi$ over time using the information on the realized values of the $x_{a}$ 's. This information is contaminated by random shocks, the $\varepsilon_{a}$ 's.

trating and educating its labor force (e.g. planting union agents in labor force), campaigning to collect signatures for a certification election, and fighting an employer's campaign against a union. 


\subsection{The Learning Process}

Suppose the union is monitoring an age- $a$ establishment at the beginning of some period. The union has a prior belief about the establishment's $\chi$. This prior is normally distributed, with mean and variance denoted by $\zeta_{a-1}$ and $\sigma_{\zeta_{a-1}}^{2}$, respectively. The establishment draws a new value, $x_{a}$, observed by both the union and the establishment. Using Bayes' Rule, the union then obtains a posterior distribution for $\chi$ with mean

$$
\zeta_{a}=\theta_{a} \zeta_{a-1}+\left(1-\theta_{a}\right) x_{a}
$$

and variance

$$
\sigma_{\zeta_{a}}^{2}=\frac{1}{\sigma_{\varepsilon}^{-2}+\sigma_{\zeta_{a-1}}^{-2}}
$$

where

$$
\theta_{a} \equiv \frac{\sigma_{\varepsilon}^{2}}{\sigma_{\zeta_{a-1}}^{2}+\sigma_{\varepsilon}^{2}},
$$

for $a \geq 1$, and

$$
\zeta_{0}=\bar{\chi} \text { and } \sigma_{\zeta_{0}}^{2}=\sigma_{\chi}^{2}
$$

Now, consider the prior beliefs of the union about $x_{a}$. Because $\chi$ and $\varepsilon_{a}$ are both normally distributed, (1) implies that the prior distribution of $x_{a}$ is normal with a mean denoted by $\mu_{a-1}$ and variance represented by $\sigma_{a-1}^{2}$. Taking the expectation of (1) yields

$$
\mu_{a-1}=\zeta_{a-1}
$$

The variance $\sigma_{a-1}^{2}$ is given by

$$
\sigma_{a-1}^{2}=\sigma_{\zeta_{a-1}}^{2}+\sigma_{\varepsilon}^{2}
$$

Using (2) and (4), one can write the law of motion for $\mu_{a}$ as

$$
\begin{aligned}
\mu_{a} & =\theta_{a} \mu_{a-1}+\left(1-\theta_{a}\right) x_{a} \\
& =\left(1-\theta_{a}\right) \chi+\theta_{a} \mu_{a-1}+\left(1-\theta_{a}\right) \varepsilon_{a}
\end{aligned}
$$

where the initial prior, $\mu_{0}=\bar{\chi}$, is the same for all new establishments. Note that $\mu_{a}$ follows an $\operatorname{AR}(1)$ process. $^{13}$

\footnotetext{
${ }^{13}$ Equation (6) can also be written as

$$
\mu_{a}=\mu_{a-1}+\left(1-\theta_{a}\right)\left(x_{a}-\mu_{a-1}\right), \text { for } a \geq 1,
$$

Because $1-\theta_{a}>0$, values of $x_{a}$ higher (lower) than $\mu_{a-1}$ lead to an upward (downward) revision of the prior.
} 
Let $\Phi\left(x_{a} ; \mu_{a-1}, \sigma_{a-1}^{2}\right)$ be the (normal) cumulative distribution function (c.d.f.) of $x_{a}$. Note, from (3) and (5), that $\sigma_{a-1}^{2}$ changes over time only because $a$ changes, since $\sigma_{\varepsilon}^{2}$ is known. Therefore, $\Phi$ can be summarized by the pair $\left(\mu_{a-1}, a\right)$.

\subsection{The Union's Problem}

The payoff to the union from organizing an establishment is summarized by a union benefit function, $B\left(x_{a}\right)>0$, which gives the period surplus the union obtains from a unionized establishment with current productivity $x_{a}$. The benefit function $B\left(x_{a}\right)$ satisfies the following assumption.

Assumption $1 B\left(x_{a}\right)$ is bounded, strictly increasing, and strictly convex.

Assumption 1 states that the union obtains an increasingly larger surplus as the productivity of a unionized establishment increases. A higher level of $x_{a}$ would generally imply a larger, more profitable establishment. ${ }^{14}$ The exact mode of the post-unionization behavior of the establishment and the union are not specified. A union benefit function $B\left(x_{a}\right)$ satisfying Assumption 1 can be obtained from a variety of models governing the relationship between the union and an establishment, including monopoly union, right-to-manage, and efficient bargaining models. ${ }^{15}$ Appendix B gives examples of the derivation of $B\left(x_{a}\right)$ under alternative models.

There is a cost $c>0$ of organizing an establishment. This cost is known by the union and is incurred regardless of the outcome of the certification election. ${ }^{16}$ The union wins a certification

\footnotetext{
${ }^{14}$ For example, imagine an establishment whose production function is given by $\exp \left(x_{a}\right) l^{\alpha}$, where $l$ is employment and $\exp \left(x_{a}\right)$ is total factor productivity. The production function is a standard one that is frequently used. The form used for total factor productivity is typical when shocks are normal. If the establishment is in a competitive industry and could freely hire labor at the wage rate, $w$, then its employment would be given by $l\left(x_{a}\right)=\left[\exp \left(x_{a}\right) / w\right]^{1 /(1-\alpha)}$, which is strictly convex in $x_{a}$. Output and profits are also strictly convex in $x_{a}$ under reasonable specifications.

${ }^{15}$ See, for instance, Manning $(1987,1994)$ for a discussion of these different models. In the case of a monopoly union, the union picks the wage while the establishment chooses employment given the union wage. In the rightto-manage model, the union and the establishment bargain over the wage, but the latter chooses employment. In the efficient bargaining model, both the wage and employment are chosen simultaneously as a result of bargaining. In the U.S., unionization process is mainly decentralized. In some countries, centralized bargaining prevails, where a union may negotiate a common contract with several employers simultaneously.

${ }^{16}$ Estimates of union organizing costs are hard to come by. Voos (1984) presents some early estimates and finds that total real organizing expenditures per organizable worker remained relatively constant over the years
} 
election with probability $\omega_{a}$ in an age- $a$ establishment. The probability $\omega_{a}$ is an independently and identically distributed continuous random variable drawn, across establishments and over time, from a cumulative distribution function $\Gamma\left(\omega_{a}\right)$ defined on $[0,1]$. This probability is observed during the previous period before the targeting decision is made in the current period.

Let $V^{u}\left(s_{a}\right)$ represent the value that a union obtains from an age- $a$ unionized establishment, given the state of the world $s_{a} \equiv\left(\mu_{a}, a, x_{a}, \omega_{a+1}\right)$. The function $V^{u}$ is defined by

$$
V^{u}\left(s_{a}\right)=B\left(x_{a}\right)+\beta E\left[V^{u}\left(s_{a+1}\right)\right],
$$

where the $\mu_{a+1}$ component of $s_{a+1}$ is governed by the law of motion specified in (6). The expectation on the right hand side of (7) depends on the prior $\mu_{a}$. This prior is used to forecast both $x_{a+1}$ and $\mu_{a+1}$.

The union's value, $V^{n}\left(s_{a}\right)$, from a non-unionized establishment arises solely from the option to organize this establishment at some future date. This value can be written as

$$
V^{n}\left(s_{a}\right)=\beta \max \left\{\omega_{a+1} E\left[V^{u}\left(s_{a+1}\right)\right]+\left(1-\omega_{a+1}\right) E\left[V^{n}\left(s_{a+1}\right)\right]-c, E\left[V^{n}\left(s_{a+1}\right)\right]\right\} .
$$

At the beginning of the next period, the union will make a decision about whether or not to target the establishment. It makes this decision before it observes $x_{a+1}$. Therefore, it compares the expected benefit from targeting, $\omega_{a+1} E\left[V^{u}\left(s_{a+1}\right)\right]+\left(1-\omega_{a+1}\right) E\left[V^{n}\left(s_{a+1}\right)\right]-c$, with the expected benefit from not targeting, $E\left[V^{n}\left(s_{a+1}\right)\right]$.

\subsection{Union Targeting and Unionization}

A union targets an age- $a$ establishment a certification election occurs if and only if the expected net gain from targeting an establishment, $\omega_{a}\left\{E\left[V^{u}\left(s_{a}\right)-V^{n}\left(s_{a}\right)\right]\right\}$, exceeds the cost of organizing, $c$

$$
\omega_{a}\left\{E\left[V^{u}\left(s_{a}\right)-V^{n}\left(s_{a}\right)\right]\right\}>c .
$$

Now, let $D\left(s_{a}\right) \equiv V^{u}\left(s_{a}\right)-V^{n}\left(s_{a}\right)$. The targeting decision depends on the properties of she studied. 
$D\left(s_{a}\right)$. Using $(7)$ and $(8)$ one can write

$$
\begin{aligned}
& D\left(s_{a}\right) \\
& =B\left(x_{a}\right)+\beta E\left[V^{u}\left(s_{a+1}\right)\right]-\beta \max \left\{\omega E\left[V^{u}\left(s_{a+1}\right)\right]+(1-\omega) E\left[V^{n}\left(s_{a+1}\right)\right]-c_{a+1}, E\left[V^{n}\left(s_{a+1}\right)\right]\right\} \\
& =B\left(x_{a}\right)+\beta \min \left\{(1-\omega)\left(E\left[V^{u}\left(s_{a+1}\right)\right]-E\left[V^{n}\left(s_{a+1}\right)\right]\right)-c_{a+1}, E\left[V^{u}\left(s_{a+1}\right)\right]-E\left[V^{n}\left(s_{a+1}\right)\right]\right\} .
\end{aligned}
$$

By using the definition for $D\left(s_{a}\right),(10)$ reduces to

$$
\begin{aligned}
D\left(s_{a}\right) & =B\left(x_{a}\right)+\beta \min \left\{\left(1-\omega_{a+1}\right) E\left[D\left(s_{a+1}\right)\right]-c, E\left[D\left(s_{a+1}\right)\right]\right\}, \\
& =B\left(x_{a}\right)+\beta\left\{\left(1-\omega_{a+1}\right) E\left[D\left(s_{a+1}\right)\right]-c\right\},
\end{aligned}
$$

where $\mu_{a+1}$ in $s_{a+1}$ is governed by the law of motion (6). The second equality in (11) holds because $1-\omega_{a+1}<1, c>0$, and $D\left(s_{a}\right) \geq 0 .{ }^{17}$ The function $D$ has the following properties.

Lemma 1 (Properties of $D$ ) There exists a unique, continuous and bounded function $D\left(s_{a}\right)$ that satisfies (11). $D\left(s_{a}\right)$ is increasing and strictly convex in $\mu_{a}$, increasing in $x_{a}$, and decreasing in $a$ and $c$. Furthermore, $E\left[D\left(s_{a}\right) \mid \mu_{a-1}, a\right]$ is increasing in $\mu_{a-1}$ and decreasing in a.

Proof. See Appendix A for all proofs.

From the targeting rule (9) and Lemma 1, for any given $a$ there exists a unique threshold, $\widetilde{\omega}\left(\mu_{a-1}, a\right)$, defined by

$$
\widetilde{\omega}\left(\mu_{a-1}, a\right)=\frac{c}{E\left[D\left(s_{a}\right) \mid \mu_{a-1}, a\right]},
$$

such that the union targets an establishment whenever $\omega_{a}>\widetilde{\omega}\left(\mu_{a-1}, a\right)$. The probability of targeting an age- $a$ establishment, $T\left(\mu_{a-1}, a\right)$, is then given by

$$
T\left(\mu_{a-1}, a\right)=1-\Gamma\left(\widetilde{\omega}\left(\mu_{a-1}, a\right)\right) .
$$

The main results can now be presented. Who do unions target? Proposition 1 answers this question.

Proposition 1 (Unions target productive, young firms.) The probability of the union targeting an establishment, $T\left(\mu_{a-1}, a\right)$, is increasing in $\mu_{a-1}$ and decreasing in a.

\footnotetext{
${ }^{17}$ The non-negativity of $D\left(s_{a}\right)$ follows because $V^{n}\left(s_{a}\right)$ cannot exceed $V^{u}\left(s_{a}\right)$.
} 
By Proposition 1, the probability of the union successfully organizing an establishment

$$
O\left(\mu_{a-1}, a\right)=\omega_{a} T\left(\mu_{a-1}, a\right),
$$

is also increasing in $\mu_{a-1}$ and decreasing in $a$. A higher value for $\mu_{a-1}$ implies that the union believes that the establishment will yield a greater stream of benefits. Hence, the probability of union targeting and successful organizing rises. As an establishment ages, the variance around the prior declines, in line with (3) and (5). This reduces the probability that a high value for $x_{a}$ will be drawn. The decline in the variance around the prior leads to a lower expected value for the union, given the strict convexity of $D$, and hence a lower likelihood of targeting and successfully organizing an establishment.

Next, consider the expected probability of union win in a certification election conditional on the union targeting an age- $a$ establishment. Using (9), this probability can be written as

$$
W\left(\mu_{a-1}, a\right)=E\left[\omega_{a} \mid \omega_{a}>\widetilde{\omega}\left(\mu_{a-1}, a\right)\right] .
$$

Note that $W\left(\mu_{a-1}, a\right)$ depends on $\mu_{a-1}$ and $a$, even though the unconditional probability of win, $\omega_{a}$, is assumed to be an i.i.d. random variable independent of $\mu_{a-1}$ and $a . W\left(\mu_{a-1}, a\right)$ satisfies the following properties.

Proposition 2 (Unions win elections in less productive, older firms) The expected probability of union win conditional on the establishment being targeted, $W\left(\mu_{a-1}, a\right)$, is decreasing in $\mu_{a-1}$ and increasing in a.

For the union to win in a targeted establishment, it must have a sufficiently high draw of $\omega_{a}$ from the c.d.f $\Gamma$. Such a draw is less likely when the establishment is more productive and younger, corresponding to a higher threshold, $\widetilde{\omega}\left(\mu_{a-1}, a\right)$.

The probability that an age- $a$ establishment, with a history of priors $\left(\mu_{a-1}, \mu_{a-2}, \cdots, \mu_{0}\right)$, is unionized is given by

$$
\begin{aligned}
U\left(\mu_{a-1}, \mu_{a-2}, \cdots, \mu_{0}, a\right) & =\sum_{j=1}^{a}\left\{\prod_{k=1}^{j-1}\left[1-O\left(\mu_{k-1}, k\right)\right]\right\} O\left(\mu_{j-1}, j\right) \\
& =1-\prod_{j=1}^{a}\left[1-O\left(\mu_{j-1}, j\right)\right] .
\end{aligned}
$$

Observe that $U$ is the probability that unionization occurs by the $a$-th trial, where the probability of success in trial $j$ is $O\left(\mu_{j-1}, j\right)$. The following can be stated about unionized establishments. 
Proposition 3 (Unionization is prevalent in productive, old firms.) The probability of an establishment being unionized, $U\left(\mu_{a-1}, \mu_{a-2}, \cdots, \mu_{0}, a\right)$, is increasing in $\mu_{a-1}$ and $a$.

A rise in $\mu_{a-1}$ increases the probability that the union is targeted in the current period, if it hasn't been organized in the past. Clearly, the chances that an establishment is unionized in the current period are then higher. An increase in age, $a$, raises the likelihood that the establishment is organized, since it increases the time interval over which the union could have potentially engaged in targeting activity.

\subsection{Testable Implications}

Consider now an outside observer (an econometrician) who sees $x_{a}$ and $a$, but not the union's prior, $\mu_{a-1}$. The observer knows the distribution of $\mu_{a-1}$ given $x_{a}$ and $a$, the distribution of $\omega_{a}$, and the union's probability of targeting, $T\left(\mu_{a-1}, a\right)$. Given $x_{a}$ and $a$, the observer has beliefs on $\mu_{a-1}$, represented by the c.d.f. $\Omega\left(\mu_{a-1} \mid x_{a}, a\right)$. Based on these beliefs, the observer's assessment of the probability that the union targets an age- $a$ establishment with current productivity $x_{a}$ is

$$
T^{o}\left(x_{a}, a\right)=\int T\left(\mu_{a-1}, a\right) d \Omega\left(\mu_{a-1} \mid x_{a}, a\right) .
$$

Which establishments will an observer see the union target? An answer to this question is provided in Proposition 4.

Proposition 4 (The probability of targeting from the observer's perspective) The probability of targeting from the observer's perspective, $T^{o}\left(x_{a}, a\right)$, is increasing in $x_{a}$.

Proposition 4 implies the likelihood of targeting is higher for higher values of $x_{a}$. How $T^{o}\left(x_{a}, a\right)$ changes as $a$ increases, however, depends on the magnitudes of two opposing effects. For any given $x$,

$$
T^{o}(x, a+1)-T^{o}(x, a)=\int T(\mu, a+1) d \Omega(\mu \mid x, a+1)-\int T(\mu, a) d \Omega(\mu \mid x, a) .
$$

By Proposition 1, $T(\mu, a+1) \leq T(\mu, a)$. This effect implies that $T^{o}(x, a+1)$ is no larger than $T^{o}(x, a)$, ceteris paribus. However, $\mu$ has a lower variance when $a$ is higher. Depending on the curvature of $T$, the effect on $T^{o}$ of a lower variance for $\mu$ can be positive or negative. ${ }^{18}$ Thus,

\footnotetext{
${ }^{18}$ If $T$ is stricly concave (strictly convex) in $\mu$, a reduction in the variance of $\mu$ implies a higher (lower) $T^{o}$.
} 
the sign of (16) depends on the nature of $T$. Which effect dominates in practice is an empirical question. For instance, if the first effect dominates, $T^{o}$ is decreasing in $a$.

For the observer, the probability of the union successfully organizing an establishment is given by $O^{o}\left(x_{a}, a\right)=\int \omega_{a} T^{o}\left(x_{a}, a\right) d \Gamma\left(\omega_{a}\right)$. The probability $O^{o}$ shares the properties of $T^{o}$ in Proposition 4. Furthermore, the observer's assessment of the expected probability of union win conditional on targeting, $W^{o}\left(x_{a}, a\right)=\int W\left(\mu_{a-1}, a\right) d \Omega\left(\mu_{a-1} \mid x_{a}, a\right)$, satisfies the following.

Proposition 5 (The probability of union win from the observer's perspective) The expected probability of union win (conditional on targeting) from the observer's perspective, $W^{o}\left(x_{a}, a\right)$, is decreasing in $x_{a}$.

As in the case of $T^{o}\left(x_{a}, a\right)$, how $W^{o}\left(x_{a}, a\right)$ depends on $a$ is dictated by the shape of $W\left(\mu_{a-1}, a\right)$. Consider next the probability $U^{o}\left(x_{a}, a\right)$ that an age- $a$ establishment with productivity $x_{a}$ is a union establishment from the observer's perspective. Let $\Psi\left(\mu_{a-1}, \mu_{a-2}, \cdots, \mu_{0} \mid x_{a}, a\right)$ denote the joint c.d.f. associated with the history of priors for an age- $a$ establishment, conditional on $x_{a}$. Then,

$$
U^{o}\left(x_{a}, a\right)=\int U\left(\mu_{a-1}, \mu_{a-2}, \cdots, \mu_{0}, a\right) d \Psi\left(\mu_{a-1}, \mu_{a-2}, \cdots, \mu_{0} \mid x_{a}, a\right) .
$$

What type of establishments will an observer see unionized?

Proposition 6 (The probability of unionization from the observer's perspective) The probability of being a union establishment from the observer's perspective, $U^{o}\left(x_{a}, a\right)$, is increasing in $x_{a}$ and $a$.

Now, consider any proxy for $x_{a}$ (any monotonic function of $x_{a}$ ). Because the c.d.f.'s $\Omega$ and $\Psi$ in (15) and (17) remain the same if the conditioning is done on the proxy, the probabilities $T^{o}$ and $U^{o}$ don't change if $x_{a}$ is replaced by the proxy. Therefore, Propositions 4-6 hold for proxies. In relating the probabilities $T^{o}, O^{o}$, and $U^{o}$ to $x_{a}$ in empirical analysis, one can thus use variables such as establishment size or measures of productivity as proxies, to the extent they are monotonic functions of $x_{a}$, which is the case under reasonable specifications of the production function.

The cost of union organizing, $c$, has been assumed to be a constant for simplicity. This cost can depend on the pair $\left(\mu_{a-1}, a\right)$. For instance, unions may have a lower cost of organizing 
in younger and less productive establishments, where managerial inexperience may underlie both lower productivity and an inability to counter union activity. In that case, as $\mu_{a-1}$ or $a$ increases, the targeting decision depends on how fast the cost $c$ increases relative to the net benefit from targeting, $E\left[D\left(s_{a}\right) \mid \mu_{a-1}, a\right]$. The model also ignores the likelihood of union decertification, which is a rare event. For simplicity, it also abstracts from establishment exit and any potential effects of unionization on exit likelihood. In the data, the observed likelihood of unionization $U^{o}\left(x_{a}, a\right)$ depends both on the union decertification rate and the exit rate of unionized establishments. It is an empirical question whether these rates alter any of the predictions in Propositions 4-6.

\section{Empirical Methodology}

The model has predictions regarding four main events associated with unionization over the life-cycle of an establishment. These events are the first time that an establishment is targeted by a union (the first certification election), a union win in the first certification election conditional on the establishment being targeted, the first successful organization (the first certification election and union win), and the union status of an establishment at any point in time. Each of these probabilities are explored using the model's predictions.

It is important to note the sequence of events leading to union certification in an establishment for understanding the definition of these probabilities. Dinardo and Lee (2004) provide a brief summary of these events. ${ }^{19}$ A collection of workers in an establishment aim to get organized and form a union. These workers typically contact a union, seeking assistance with organizing. With the help of the union, workers carry out a card drive, during which they try to obtain cards from at least 30 percent of the workers to be legally granted an election by the NLRB. The NLRB then makes a determination on what constitutes the bargaining unit for the workers trying to organize. A certification election is then held among workers eligible to vote. This event is referred to as "union targeting" here. A simple majority is required for a union win in the election. Within 7 days after the ballot tally, objections can be made by both parties, and a re-election can be granted by NLRB if there is sufficient evidence of an improperly carried out election. At the end, if the union has simple majority, the union is

\footnotetext{
${ }^{19}$ See Section II of Dinardo and Lee (2004).
} 
certified as the exclusive bargaining agent for the bargaining unit, and the employer is obliged to negotiate in good faith with the union. The event of this exclusive right being granted to the union is labelled here as "successful organizing". This right is lost the union loses a subsequent decertification election, which is either petitioned by the employer (in the event of a business restructuring), or by a sufficient number of workers whose jobs are represented by the union. An establishment is labelled here as "unionized" until such an event occurs.

An establishment may have been targeted by a union before its first-ever certification election with no resulting election (a failed card drive). Such cases are unfortunately not observed in the data. The first-ever targeting of an establishment by a union is thus defined as the first-ever union organizing drive that leads to a certification election. This selection based on an election may itself be important. It is plausible that unions are less likely to secure an election when they target establishments that are able to resist unionization successfully. Such establishments may be larger, productive, and may offer higher wages. If this is the case, unobserved targetings with no resulting election may be disproportionately concentrated in larger or productive establishments. An implication is that any positive association found between union targeting and establishment productivity or size would be stronger if targetings with no resulting election were also observed.

Clearly, an establishment may also experience more than one certification election along its life-cycle, for the same or different bargaining units in the establishment. Only a small fraction of establishments $(<5 \%)$ in the data experience two or more certification elections over their life-cycles. Subsequent targetings and successful organizations likely depend on the outcome of the first targeting, and hence, cannot be treated as independent events. As such, they are excluded from the analysis. The union status of an establishment, however, takes into account the outcome of all certification elections that the establishment experiences. That is, if an establishment experiences more than one certification election, a union win in any of these elections results in unionization and the establishment then stays unionized until either it exits or a union decertification election takes place in the establishment.

Let $E_{i t}$ be the indicator that event $E$ occurs in a establishment $i$ in year $t$, where $E \in$ $\{T, W, O, U\}$ denotes the event of first-ever targeting by a union $(T)$, union win in the first-ever certification election $(W)$, the first successful organizing by a union $(O)$, or the event that an establishment is a union establishment $(U)$. The observer's assessed probability, $E^{o}\left(x_{i t}, a_{i t}\right)$, 
that an establishment experiences event $E$ is modelled using the following inverse logit transformation $^{20}$

$$
E^{o}\left(x_{i t}, a_{i t}, y_{i t} ; \mathfrak{b}\right)=\frac{\exp \left(F\left(x_{i t}, a_{i t}, y_{i t} ; \mathfrak{b}\right)\right)}{1+\exp \left(F\left(x_{i t}, a_{i t}, y_{i t} ; \mathfrak{b}\right)\right)}
$$

where

$$
F\left(x_{i t}, a_{i t}, y_{i t} ; \mathfrak{b}\right)=b_{0}+\sum_{j=1}^{J} b_{x}^{j} I^{j}\left(x_{i t}\right)+\sum_{k=1}^{K} b_{a}^{k} I^{k}\left(a_{i t}\right)+b_{y}^{\prime} y_{i t}+\iota_{i}+s_{i}+\tau_{t} .
$$

In (19), $x_{i t}$ is classified into one of $J$ bins, where $I^{j}\left(x_{i t}\right)$ is the indicator that $x_{i t}$ falls in bin $j$. Similarly, $a_{i t}$ is classified into one of $K$ bins, with the corresponding indicator $I^{k}\left(a_{i t}\right)$. These specifications offer a flexible way of accounting for the effects of productivity and age, which are not necessarily linear according to the theoretical model. The variable $y_{i t}$ is a vector of controls, $\iota_{i}$ is an industry fixed effect, $s_{i}$ is a state (geography) fixed effect, and $\tau_{t}$ is a year fixed effect, and $\mathfrak{b} \equiv\left\{b_{0},\left\{b_{x}\right\}_{j=1}^{J},\left\{b_{a}\right\}_{k=1}^{K}, b_{y}\right\}$ is the set of parameters.

The parameters $\mathfrak{b}$ in (19) can be estimated for each event $E \in\{T, W, O, U\}$ separately by maximizing a weighted log-likelihood function

$$
\mathcal{L}(\mathfrak{b})=\sum_{t=t_{0}}^{\bar{t}} \sum_{i=1}^{n_{t}} w_{i t} E_{i t} \ln E^{o}\left(x_{i t}, a_{i t}, y_{i t} ; \mathfrak{b}\right)+\left(1-w_{i t} E_{i t}\right) \ln \left(1-E^{o}\left(x_{i t}, a_{i t}, y_{i t} ; \mathfrak{b}\right)\right)
$$

where $t=t_{0}, t_{0}+1, \ldots, \bar{t}$ denotes a year and $n_{t}$ is the total number of establishments at risk for event $E$ in year $t .{ }^{21}$ Weights, $w_{i t}$, are assigned to establishments to account for the uncertainty with which they match to certification elections. The matching and weighting procedure is explained in more detail in the next section. For an establishment that matches with a given certification election, the weight $w_{i t}$ takes on a value in $(0,1]$ equal to the inverse of the frequency of matches for that certification election. The weight $1-w_{i t}$ is then assigned to the establishment's non-matched version. If an establishment is not matched at all to any certifica-

\footnotetext{
${ }^{20}$ For instance, for the observer's probability of union targeting, $E^{o}\left(x_{i t}, a_{i t}\right)=T^{o}\left(x_{i t}, a_{i t}\right)=$ $\int T\left(\mu_{a-1}, a\right) d \Omega\left(\mu_{a-1} \mid x_{a}, a\right)$ is approximated by an inverse logit transformation.

${ }^{21}$ For the event of first-ever certification election, the establishments at risk are those that have never experienced a certification election before; for the event of a union win in a certification election, the establishments at risk are the ones that experience their first certification election; for the event of a successful organization, the establishments at risk are those that are targeted for the first time and experience a union win in the certification election; finally, for the event of being a union establishment, the establishments at risk are the ones that have experienced at least one successful organization in the past and that have not exited or experienced a union decertification.
} 
tion election, the weight is $w_{i t}=0 .{ }^{22}$ The calculation of the standard errors for the estimated parameters take into account the clustering of error terms by establishment.

For all events, the focus is on the estimates of the parameters $\left\{b_{x}^{j}\right\}_{j=1}^{J}$ and $\left\{b_{a}^{k}\right\}_{k=1}^{K}$. These estimates are used to test the model's predictions in Propositions 4-6. Two strategies are followed. First, two measures of establishment size (employment and the value of shipments) are used separately as a proxy for $x_{a} \cdot{ }^{23}$ Second, some measures of productivity are used to proxy for $x_{a}$. These are the value of shipments per worker, value added per worker, and a measure of total factor productivity. Establishment age, measured by the number of years elapsed from the first observation of an establishment, is included in all estimations in accordance with (19).

In the control variables, $y_{i t}$, a multi-unit firm indicator is included to assess the effect of being part of a multi-unit firm. A multi-unit firm association may signal to the union that the establishment belongs to a successful firm that has expanded. A firm-level unionization indicator is also included. This indicator equals one if the establishment is part of a firm that already has at least one unionized establishment. This variable accounts for potential spillover of unionization within a firm. Firm union presence may signal to the union that the establishment is more prone to unionization. Hence, both the multi-unit and firm union status are expected to contribute to the union's learning about an establishment's eligibility for being organized. Figure 1 suggests that unions indeed seek information on these characteristics for potential organizing.

Another indicator variable in $y_{i t}$ takes on a value of one if the establishment is located in a right-to-work state. During the sample period three states adopted a right-to-work law or amended it, so this indicator varies over time for these states, allowing for the identification of the corresponding coefficient in the presence of state fixed effects. ${ }^{24}$ Right-to-work states generally have laws and regulations less favorable for union activity. Additionally, establishments

\footnotetext{
${ }^{22}$ In estimations using the Economic Census sample, the establishment's sampling weights in the Economic Census are also used to arrive at population estimates.

${ }^{23}$ This approach is similar to those adopted in some other studies of firm learning (e.g. Dunne, Roberts, and Samuelson (1989)).

${ }^{24}$ Idaho and Oklahoma adopted a right-to-work law in 1986 and 2002, respectively. In 1993, Texas amended its original right-to-work law passed in 1947. Whether Texas is included in this group of three states does not alter the estimates materially. For a chronology of the adoption of right-to-work laws by states, see http://www.dol.gov/whd/state/righttowork.htm.
} 
may favor location in these states because such states tend also to foster other policies friendly to businesses. ${ }^{25}$ Union organizing activity may therefore be less intense in such states. In the estimation of the probability $W^{o}$, the ratio of the workers eligible to vote in the certification election to the establishment's total employment is also included in $y_{i t}$. The higher this ratio, the higher the stakes for the union and the establishment in the election. Therefore, both the union and the management in the establishment may devote more resources to influence the outcome of the certification election. As a result, the effect of this ratio can go in either direction.

For each event of interest, the estimation is carried out for all private sector establishments, and also separately for the manufacturing sector, where unionization has traditionally been more concentrated. For specifications using an establishment's employment as a measure of size, the sample period for estimation is 1977-2007, as employment data are available annually. For specifications where value of shipments or measures of productivity are used, the sample period includes only the Economic Census years (every five years between 1977 and 2007, inclusive), as these variables are available only in the Economic Census, as discussed in the next section (except in the case of total factor productivity, which can be calculated for 1977-2007 using the Census of Manufactures). In all estimations, the sample excludes those establishments that entered before 1977, because for such establishments there is no information on prior union activity before 1977, as is discussed in the next section.

\section{Data}

National Labor Relations Board (NLRB) certification election data for the years 1977-2007 is linked with the corresponding years from the U.S. Census Bureau's Longitudinal Business Database (LBD), quinquennial revenue data from the Economic Census (EC), and data on total factor productivity from the Census of Manufactures. ${ }^{26}$ The NLRB data contain information

\footnotetext{
${ }^{25}$ For instance, Holmes (1998) documents the sharp increase in manufacturing activity when one crosses the border from a non-right-to-work law state to one with a right-to-work law. As Holmes notes, the law itself may not be the cause of this increase. The presence of the law in a state may serve as a proxy for other business-friendly policies and regulations of the state.

${ }^{26}$ The NLRB certification election data come from two sources: the 1977-1999 data was kindly provided by Thomas J. Holmes; data from 1999-2007 is available from data.gov.
} 
on union certification and decertification elections that took place between 1977-2007. NLRB elections in the year 1977 are only partially observed, see Appendix C. For each election, the data contains the employer's name, address, and industry. It also contains the number of workers eligible to participate in the election, how many ballots were cast, and how many were cast in favor of the union.

Over the sample period, the NLRB data contain information on a total of 103,064 certification elections. ${ }^{27}$ In most years there are roughly 3, 000 certification elections. The frequency of these elections in general declines over the sample period. In particular, the number of certification elections drops sharply from about 9,000 in 1977 to about 3,500 in 1983, and continues to drift lower for the rest of the period, with about 1,600 elections in 2007. For an analysis of the trends in NLRB elections, see Appendix C.

The LBD, with which the NLRB elections data is matched, contains the universe of private sector employers in the U.S. at the establishment level. Key variables are the number of employees, industry affiliation, location, the year the establishment enters and exits, and the identifier of the firm that has operational control over the establishment. The LBD is also matched at the establishment level with the EC, which is conducted every five years. This match is done for each quinquennial census between 1977 and 2007, inclusive. The time series coverage by the EC varies by industry. ${ }^{28}$ The data collected permit the construction of a revenue-based labor productivity measure, that is, the value of shipments per employee, for all industries. Another measure of labor productivity, value added per worker, is available for manufacturing, and is used as an alternative to the value of shipments-based one. A total factor productivity measure is also used for manufacturing.

NLRB data is consistently available by the employer's name and the employer's city and

\footnotetext{
${ }^{27}$ The 497 of elections that are labelled "Union Shop Clause" are omitted from all empirical specifications, as these only appear in the data obtained from data.gov. The 3,418 "Employer Requested" elections are also omitted, as these tend to be elections that are sought when some fraction of the workforce was previously unionized.

${ }^{28}$ The Census of Construction Industries, the Census of Manufactures, the Census of Retail Trade, the Census of Services, and the Census of Wholesale Trade are available every five years from 1977-2007. Other parts of the economy are only available for more recent years. The Census of Finance, Insurance, and Real Estate is available for 1992-2007, the Census of Mining and the Census of Transportation, Communications, and Utilities are available for 1987-2007, and the Census of Finance, Insurance, and Real Estate are available for 1992-2007.
} 
state. The LBD is linked to the NLRB data via a multi-stage matching process. Each stage involves considering establishments in both the LBD and the NLRB data at some level of geography - city and state, fuzzed city name and state, or county and state. Having so "blocked" the data at a particular level of geography, the similarity of business names and industry are considered between the two data sets. Inspection of individual records is used to validate the name and industry agreement rules, along with inspection of the address and zip code that are available consistently for the LBD data, and also for a subset of the years of the NLRB data. The NLRB data contains the number of employees eligible to vote in the certification election. This information is used to reject potential matches, while allowing for the somewhat uncommon event of multiple establishments being included in the same certification election (for example, an election might cover all cashiers in a particular geographic region of a retail chain). If the size of the firm that has operational control over the establishment is less than $80 \%$ of the number of employees eligible to vote in the election matched to the establishment, then the match is rejected, and another match is sought. For establishments that have less employees than the number eligible, a progressive search is performed within the firm at increasingly higher levels of aggregation (the address, city, county, state, and national level) until the total number of LBD employees is at least $80 \%$ of the number eligible to vote in the election. ${ }^{29}$ About $73 \%$ of certification elections match reliably with the LBD for the sample period.

Weights are calculated to account for the uncertainty of matching an election to an establishment. If there are multiple establishments matched to a given certification or decertification election in a year, each establishment receives a weight, $w_{i t}$, equal to the inverse of the total number of such matches. For simplicity, and for longitudinal consistency in the case of the relatively few establishments that link to more than one election (certification or decertification), the largest weight that an establishment receives among all such elections is given as its weight over time. Each establishment involved in a multiple match was also given an additional weight, equal to $1-w_{i t}$, to represent the non-unionized version of this establishment. The sampling weights in EC were also retained to be used in the analysis to make inference about the population of establishments in the estimations using EC data for size and productivity

\footnotetext{
${ }^{29}$ This rule was established using the records downloaded from www.data.gov as training data. This data contains a free-form text description field that often includes the phrase "at all" when describing elections that cover multiple establishments.
} 
measures.

Both the NLRB data and the LBD are left-censored. The NLRB data available for this study begins in 1977, and an establishment's union status is unknown if it entered prior to 1977. Therefore, there is no way of identifying whether a certification election that occurs during the 1977-2007 period at such an establishment is, in fact, that establishment's first certification election. Furthermore, the LBD is the universe of employer establishments starting in 1975. For establishments that first appear in 1975, there is no entry year, hence, no age information. To be able to identify age and union status accurately, the analysis is therefore restricted to all establishments that first appear in LBD in or after 1977.

The dataset used contains a weighted sum of nearly 30 million establishments, and about 89,400 establishments match to certification elections. Of those that match to an election, about $95 \%$ match to exactly one election, and about $4 \%$ match to exactly two elections. Most of the remainder match to exactly three elections. Thus, the cases where multiple certification elections occur at a given establishment are rare. Less than half of the elections occur in establishments that are left-censored, and the remainder are among those establishments that entered during or after the year 1977. This skewness reflects the fact that between 1981 and 1982 the number of certification elections dropped from 6,000-7,000 to around 3,000 per year and never recovered to its previous level. ${ }^{30}$

\section{Results}

\subsection{Size and Age Effects}

How are the probabilities of interest related to establishment age and size, as measured by employment or the value of shipments? Tables 1, 2, and 3 present the estimated odds ratios based on the estimation of the logit model in (18) for all private sector and manufacturing, respectively. Figures 3 and 4 contain the predicted marginal effects of size and age, and also, of year, to explore the trends. ${ }^{31}$ The discussion focuses on the predicted marginal effects in

\footnotetext{
${ }^{30}$ This sharp drop in early 1980's is also documented by other researchers, see, e.g. Farber and Western (2001).

${ }^{31}$ The marginal effect of a given size or age category is calculated by averaging the estimated probability over all observations that fall into that category.
} 
these figures, as they are easier to interpret. The estimates for all other variables are based on the specification that uses employment as the measure of size, rather than the value of shipments. The specification with employment is estimated using all years of data, whereas the value of shipments is available only every five years, effectively reducing the sample size by $80 \%$. Therefore, the effects of all other variables are more precisely estimated in the specification with employment as the size measure, and the year effects are obtained for all years, rather than every five years.

Consider first the predicted probabilities of union targeting in Figures 3 and 4 . The probability of targeting increases with both measures of size, although in manufacturing sector the size effect tapers off and declines slightly at very large employment classes. When the entire private sector is considered, an establishment in the largest employment (value of shipments) class has almost 10 (4) times the probability of being targeted compared with an establishment in the smallest size class. In manufacturing, this relative likelihood is much higher, 23 (49). Age effects for the manufacturing sector suggest that union targeting activity is at its peak within the first couple of years after an establishment's entry and flattens out after 10 to 12 years following entry. The age effects indicate a similar decline in the likelihood of targeting over time in the case of the entire private sector. For the entire private sector, the youngest group of establishments are about 1.76 times more likely to be targeted compared with the oldest group. In manufacturing, this relative likelihood is around 1.72. These patterns are consistent with a learning process and support Propositions 1 and 4. The theoretical analysis suggests that the probability of a union targeting an establishment should be increasing in productivity (size) and decreasing in age. The predicted marginal effects for year in Figures 3 and 4 also point to a decline in the probability of targeting over the sample period. This secular decline in union organizing activity is one reason behind the decline in private sector unionization in the U.S..

Next, turn to the predicted probability of a union win in a certification election, conditional on an establishment being targeted by a union. In general, the predicted probability of a win declines as establishment size increases, consistent with Propositions 2 and 5. For the case of manufacturing, in the largest employment (value of shipments) category the probability of win is about $22 \%(30 \%)$, and about $60 \%(50 \%)$ in the smallest category. The likelihood of win does not appear to change substantially with establishment age. When the entire private sector is considered, the union win likelihood also declines as establishment size increases, 
regardless of the size measure. Overall, there is evidence that unions are less successful in winning certification elections in larger establishments. Larger establishments may be better in campaigning against unions in certification elections, perhaps due to better management, organizational capabilities, and better labor conditions and compensation. The year effects indicate that, for much of the sample period, the probability of a union win has had little or no trend, with one exception: there is some rise in the union win likelihood starting in the early 2000's when the entire private sector is considered. The relatively stable average union win likelihood in certification elections, combined with the declining union targeting activity, implies a declining rate of unionized business formation over the years.

Consider now the predicted probability that a union organizes an establishment successfully for the first time. These are also presented in Figures 3 and 4. In manufacturing, the probability of successful organizing increases as both measures of establishment size increase. Therefore, the decline by size in the likelihood of a union win in a certification election is not enough to overcome the steep increase in the likelihood of targeting with size. For the largest employment (value of shipments) class, the probability of the union successfully organizing an establishment is nearly 15 (30) times the probability in the smallest class. The likelihood of successfully organizing an establishment in the manufacturing sector declines with age, as a consequence of the fact that the likelihood of targeting declines with age, whereas the likelihood of a union win in an election is not significantly different across age categories. For the entire private sector, the likelihood of successful organizing in the largest employment (value of shipments) category is about 12 (5) times that of the smallest category. Note also that likelihood of successful organizing declined persistently over the sample period, as indicated by the year effects.

Next, observe that the effects of size and age on the probability of being a union establishment are highly pronounced. Larger and older establishments are more likely to be unionized. Considering the entire private sector, establishments in the largest employment (value of shipments) size class are about 11 (4) times more likely to be unionized, compared with the ones in the smallest class. In manufacturing, this relative likelihood is about 7 (12). The age effects indicate that the oldest group of establishments are about 10 times more likely to be unionized compared with the youngest group when all sectors are considered, and 21 times more likely in manufacturing. The relationship between unionization likelihood, on the one hand, and the establishment size and age, on the other, provide support for Propositions 3 and 6. The year 
effects indicate that the probability of being a union establishment has declined substantially since late 1970's. As mentioned before, this is in part driven by the decline in the rate of certification elections shown in Figures 3 and 4, as the probability of union win in a certification remained relatively stable over. Exit of union establishments and union decertification also contribute to deunionization. The former effect is a much bigger source of union dissolution compared with the latter, which is a rare event. ${ }^{32}$ While these two modes of union dissolution are not the focus of this study, their effects across size and age categories do not appear to be large enough to alter the monotonic size and age effects predicted by Propositions 3 and 6 .

The age effects pertain to all establishments that were born in or after 1977. The year effects indicate that there was a much higher rate of union organizing activity in the late 1970s and early to mid 1980s. This higher rate of organizing activity can lead to a disproportionate targeting of young firms born in late 1970s and early 1980s, possibly resulting in a spurious negative correlation between age and union targeting likelihood (though the year effects could absorb some of this effect). As a robustness check for the age effects, all estimations were repeated after restricting the sample to the 1990-2007 period. The results are shown in Tables C.1 and C.2 in Appendix C. All estimated odds ratios, including those for age categories, are largely similar in magnitude and significance to those obtained in Tables 1 and 2. Therefore, the results do not seem to be driven by the much higher rate of union organizing activity in the early part of the sample period.

Small establishments with less than 5 employees may match to some certification elections as a result of the matching algorithm, even though these establishments may not have substantial union activity associated with them. Employment, age, and other data associated with these establishments may also in general be subject to more measurement error compared to larger ones. In addition, these establishments tend to be young. The age effects found in the estimations may therefore be in part driven by these establishments. As another robustness check, the estimations in Tables 1 and 2 were repeated after excluding small firms with 1-4 employees. The results are shown in Tables C.3 and C.4 in Appendix C. The size and age effects remain significant and qualitatively similar to those reported in Tables 1 and 2.

In results not reported, the differences in the age effects for establishments of multi-unit

\footnotetext{
${ }^{32}$ Less than $1 \%$ of union establishments experience a decertification election over the sample period, as discussed in Appendix C.
} 
versus single-unit firms were also explored. For this purpose, interaction variables between multi-unit dummy and age categories were added to the specifications in Tables 1 and 2. For manufacturing, the age effects observed in union targeting remain significant and become even more negative for establishments of single-unit firms, but there is little evidence that age matters much for establishments of multi-unit firms. When all private sector is considered, the effects of age are somewhat less pronounced for both types of establishments.

\subsection{The Effects of Other Controls}

Other controls included in the model (18) have effects that are generally consistent with what was expected a priori, as can be seen in Tables 1 and 2. Establishments that are part of a multi-unit firm and have at least one unionized sister establishment have a higher relative likelihood of experiencing union certification elections. In manufacturing, multi-unit status and having a sister establishment that is unionized each double the likelihood of being targeted by a union. When all sectors are considered, the relative likelihoods are higher: about 5.5 and 3.5, respectively, for multi-unit status and firm-union status. Unions win certification elections with a higher relative likelihood in cases where there is already at least one unionized establishment in a firm (37\% versus 56\% win rate in manufacturing). Multi-unit status has the opposite effect on the relative likelihood of win (44\% versus $38 \%$ win rate in manufacturing), consistent with unions winning elections with lower likelihood in larger establishments. Establishments that are part of a multi-unit firm, and establishments that have unionized sister establishments, are more likely to be unionized. All sectors taken together, the predicted probability of being a union establishment is about 3 times larger if an establishment is part of a multi-unit firm. This probability is also nearly 5 times larger, if there is at least one sister establishment that is already unionized. In manufacturing, these relative likelihoods are about 2.7 and 2.8 , respectively.

When state fixed effects are controlled for (as done in Tables 1 and 2), the right-to-work status of a state usually does not have a highly significant effect on targeting, union win in certification elections, or union status. With state effects included, the coefficient for the right-to-work law status is identified only through a small number of states that changed their status during the sample period. The effect of the law does not seem to be estimated with precision. When state fixed effects are not included in the estimations, establishments located 
in states with a right-to-work law are significantly less likely to be targeted. ${ }^{33}$ For example, in manufacturing the predicted marginal effect of being located in a non-right-to-work law state on union targeting is about 1.5 times that of being located in a right-to-work law state. Unionization rates are also lower in right-to-work law states. In manufacturing, the predicted likelihood of being a union establishment in a right-to-work law state is about half that in a non-right-to-work law state.

Finally, the share of employees in an establishment eligible to vote in a certification election consistently tends to be negatively associated with the likelihood of a union win. One possible explanation for this effect is that when a large fraction of the employees are at risk of becoming organized, the management in the establishment may choose to devote more resources to thwarting the union campaign, resulting in a lower likelihood of a win for the union.

In general, the estimated effects of the control variables support the view that unions use signals such as multi-unit affiliation, union presence in the firm, and location in a non-rightto-work-law state to determine an establishment's eligibility for organizing, in addition to size and age signals.

\subsection{The Effects of Productivity}

Three measures of productivity are considered alternatively. The first one is an establishment's total value of shipments per employee. The appeal of this measure is that it can be calculated for all sectors in the private economy. The second measure is the value added per employee, and it is available only for certain sectors. This measure is used for manufacturing sector for comparison with the other measures. A third measure, total factor productivity, is also available for manufacturing. ${ }^{34}$ Total factor productivity is the ideal measure, theoretically speaking. From an empirical point of view, it is the most difficult to measure. All productivity measures are computed for Economic Census years - every five years between 1977 and 2007, inclusive. ${ }^{35}$

\footnotetext{
${ }^{33}$ These estimates are available upon request.

${ }^{34}$ Zoltan Wolf has kindly provided help with the data on total factor productivity. See Foster, Haltiwanger and Krizan (2001) for the details of how total factor productivity is calculated.

${ }^{35}$ In the analysis, the highest and lowest percentiles of the distributions of all productivity measures are trimmed to prevent any influence of likely outliers. The variables in dollar values used in constructing the productivity measures are not deflated. Because the empirical methodology relies on the ranking of these
} 
Table 4 presents the odds ratios obtained from the estimation of the logit model in (18) using measures of productivity instead of establishment size, and including all other controls as in Tables 1-3. The estimates for all other variables are similar to the ones in Tables 1 and 2 , and are omitted. Tables 1 and 2 give much more precise estimates for age and other controls, and complete estimates of year effects, as these estimates are based on annual data, rather than the quinquennial observations used in Table 4. The predicted marginal effects of productivity measures based on Table 4 are in Figures 5 and 6 .

Consider first the effects of productivity measures on the union targeting (election) likelihood. The probability of targeting increases as total value of shipments per employee increases, both in the case of all sectors and manufacturing. In manufacturing, establishments in the top decile are about 3.8 times more likely to be targeted compared with the bottom decile. In manufacturing, there is also a rise in the likelihood of targeting as value added per employee increases, but the effects are less pronounced and the differences across productivity percentiles are not always highly significant. The top decile of value added per employee in manufacturing is about 2.7 times more likely to be targeted compared with the bottom decile. The probability of union targeting also increases as total factor productivity increases. The top decile in manufacturing has about 2.5 times the likelihood of being targeted compared with the bottom decile. When the entire private sector is considered in Figure 6, the differences across percentiles of value of shipments per labor are less pronounced and not highly significant. The top decile is about 2.3 times more likely to be targeted compared with the bottom decile. Overall, these effects give support for Propositions 1 and 4 .

Turn, next, to the relationship between the productivity measures and the probability of union win in a certification election. In manufacturing, there is some decline in this probability as productivity increases, except in the case of total factor productivity. This pattern gives some support to Propositions 2 and 5. In manufacturing establishments experiencing a certification election, the union win probability is about 1.6 (1.5) times higher in establishments in the bottom decile compared with the ones in the top decile, based on the value of shipments per employee (value added per employee). In the case of the entire private sector, the likelihood of a union win does not change significantly across productivity categories.

measures, instead of the absolute values, and because year fixed effects are included, there is no need for deflating. 
The predicted probability for successfully organizing an establishment follows a similar pattern to that for the first certification election. The increase in the likelihood of targeting generally overwhelms the slight decline in the likelihood of a union win in a certification election, leading to a positive association between productivity measures and the likelihood of first successful union organizing in an establishment. In the manufacturing sector, based on the value of shipments per employee (total factor productivity) unions are 2.6 (2.7) times more likely to successfully organize an establishment in the top decile of productivity compared with the bottom decile. The association between a union successfully organizing an establishment and productivity is somewhat weaker and is not highly significantly different across categories in the case of value added per employee. The top decile is about 1.8 times more likely to be successfully organized compared with the bottom decile. For the entire private sector, the estimated likelihood of successful organizing approximately doubles going from the bottom decile to the top decile of value of shipments per employee.

Finally, observe that more productive establishments are also more likely to be unionized regardless of the productivity measure. This conclusion holds for all sectors as well as manufacturing. In manufacturing, establishments in the highest productivity decile are about 3, 2.2, and 2.3 times more likely to be unionized compared with the ones in the lowest decile, for value of shipments per employee, value added, and total factor productivity, respectively. In the entire private sector, the likelihood of unionization is about twice as high in the top decile of value added per employee, compared with the bottom decile. The positive association between unionization and productivity generally support Propositions 3 and 6 .

For further robustness analysis, consider now some alternative measures of an establishment's ability to offer benefits to a union. A measure that may be relevant for a union's targeting decision is an establishment's ability to offer wages above and beyond what it currently pays to its employees. One can potentially measure this ability by using the gap between an establishment's labor productivity and average wage. Establishments that are more productive per employee, but pay a relatively low average wage, offer potentially a greater surplus to a union, which the latter can partially extract by demanding higher wages. To explore this possibility, the analysis in Table 4 was repeated using the difference between labor productivity and the average wage in an establishment in place of productivity. The results, shown in Table C.5, are generally similar to the productivity effects. Establishments that have a larger gap 
between labor productivity and average wage tend to be targeted by a union with a higher likelihood. They also tend more likely to be unionized. Furthermore, unions appear to have a lower probability of winning a certification election in establishments with a larger gap.

More generally, establishments that offer lower wages may be more likely to be targeted by unions, as demand for unionization would be higher by workers. However, some unions may also choose to target high-wage establishments because in such establishments a union can secure high wages for its members even when the union does not have a high bargaining power. A related effect is that establishments that are more likely to be targeted by a union may raise their wages to avoid unionization. ${ }^{36}$ Such an effect implies that wages cannot be treated as exogenous to the union targeting decision. ${ }^{37}$ In addition, wages in already unionized establishments are clearly affected by union presence. Finally, it is well known that larger and older establishments tend to pay higher wages. ${ }^{38}$ Given the results so far that indicate a positive association between union targeting and size, it is likely that unions target highwage establishments. A full analysis of the unionization-wage relationship is not the focus of this paper and requires a deeper exploration using the newly constructed database in this study. Here, an initial look at whether unions target high-wage establishments is provided based on the logistic regression framework used so far. Tables C.6-C.9 provide estimates of the parameters of interest by including two measures of wages in the specifications for Tables 1 and 2. The first specification (Tables C.6 and C.7) includes the logarithm of the average wage of an establishment. ${ }^{39}$ The second specification (Tables C.8 and C.9) uses the gap between the logarithm of the average wage and its predicted value based on observable characteristics of an establishment. ${ }^{40}$ This measure aims to identify establishments that pay a relatively high

\footnotetext{
${ }^{36}$ See Taschereau-Dumouchel (2012) for an analysis of this effect.

${ }^{37}$ In particular, unobserved characteristics of an establishment that lead to a higher likelihood of unionization can also drive higher wages. Therefore, the unobserved factors determining the union's expected net benefit from targeting could be positively correlated with wages.

${ }^{38}$ See, for instance, Brown and Medoff $(1989,2003)$.

${ }^{39}$ It should also be noted that the average wage pertains to all employees in an establishment, not just the ones in the potential bargaining unit. The data does not allow the separate measurement of wages for the workers that are likely to try to organize. This measurement error can be important especially when there is a large wage inequality among workers in an establishment. Note also that establishments with zero reported payroll are excluded from the analysis.

${ }^{40}$ The predicted (log) average wage is obtained from an establishment level regression of the logarithm of the
} 
average wage compared to what they would be expected to offer based on their characteristics. The results in Tables C.6-C.9 indicate that conditional on size and age, unions are more likely to target high-average-wage and high-gap establishments, but also less likely to win elections in establishments that offer higher wages or have larger gap.

\section{Discussion}

The size effects in Figures 3 and 4, and the productivity effects in Figures 5 and 6 are consistent, overall, with the main predictions of the theory. Productive and larger establishments are more likely to be targeted by unions, and more likely to be successfully organized despite a somewhat lower likelihood of a union win in certification elections in such establishments. Unionization also tends to be concentrated in productive and large establishments at any point in time. The age effects in Figures 3 and 4 also indicate that unions tend to get organized in establishments when they are younger, consistent with the learning model presented.

The productivity effects are generally less pronounced and statistically less significant than in the case of the size effects in Figures 3 and 4. This result is not an artifact of the way size and productivity categories are chosen to generate the estimates. The relatively weaker effects of productivity are apparent even when the estimates of the size effects in Figures 3 and 4 are obtained for the same percentile categories used for the productivity measures. ${ }^{41}$ There are several reasons why the productivity effects may be weaker. These effects are estimated using much smaller samples (about 20\% of the samples in the case of the size effects), decreasing the precision of the estimates to some degree. Productivity measures also contain more measurement error than size measures, as they confound the measurement errors in employment, revenue, and the costs of inputs. In addition, measures of current productivity and current size need not always be strongly related. Suppose there are adjustment costs for capital or labor.

average wage on employment, age, multi-unit status, right-to-work status, and state, 2-digit industry, and year fixed effects.

${ }^{41}$ For instance, when employment is measured in categories of percentiles, the top decile is about 30 times more likely to be targeted than the bottom decile in manufacturing. Note, from an expository point of view, that size measures expressed in terms of absolute values of employment and value of shipments are more readily interpreted than percentiles. 
Then, a temporary fall in productivity may not be associated with a decline in size. ${ }^{42}$ It is also possible that unions care more about size (employment) than the underlying productivity of an establishment. In particular, unions that value broader employment for their members would target businesses that are large, but not necessarily highly productive. Furthermore, unions may be using establishment size and sales as a strong indicator of eligibility for organizing, as they are much easier to observe than productivity. Theoretically speaking, there should exist a weaker relationship between unionization and labor productivity as measured by the value of shipments per worker. To see this, imagine an environment where non-unionized establishments choose employment given an exogenous wage common across all establishments in the economy. In such a case, non-unionized establishments with different levels of total factor productivity would hire labor up to the point where the marginal product of labor is equal (to the common wage) across establishments. ${ }^{43}$ Labor productivity would then not be related to underlying total factor productivity. Hence, it may not be related to the patterns of union targeting. One way to gauge the relative importance of size and productivity in union activity is to include both measures simultaneously in the estimations. Tables C.10 and C.11 repeat the analysis in Tables 1 and 2 by including both size (employment) and labor productivity (the value of shipments per worker) together in the estimations. These head-to-head comparisons indicate that size retains its sign and significance as in Tables 1 and 2, but labor productivity effects tend to be weaker, especially when all sectors are considered together. In manufacturing, however, the size and productivity effects still retain their signs and significance.

Note also that size and productivity effects are generally much stronger and statistically more significant in manufacturing when compared with the entire private sector. These differences may be driven by a number of reasons. One reason is the differences in the size distribution of establishments across sectors. In manufacturing, there is a higher fraction of very large establishments and a smaller fraction of small ones, compared with sectors such as retail or

\footnotetext{
${ }^{42}$ These adjustment costs may also apply to "customer capital" of a firm. In models of stochastic customer acquisition under informational frictions, such as Fishman and Rob (2002) or Dinlersoz and Yorukoglu (2012), larger firms need not necessarily have high current productivity. In general, size and productivity can also have different persistence levels.

${ }^{43}$ For instance, take a production function of the form $e^{x} l^{\alpha}$, where $l$ is labor and $e^{x}$ is the total factor productivity. If the wage is $w$, then the first order condition for labor is $\alpha e^{x} l^{\alpha-1}=w$. Labor productivity is then $w / \alpha$, which will be common across firms even if total productivity differs.
} 
services. The higher dispersion of establishment size in manufacturing implies that the size effects may be stronger and more pronounced across size categories. Another reason may be the stronger tradition of unionization in manufacturing than the rest of the economy. During the sample period 1977-2007, manufacturing employment exhibited an average union membership rate of $20.8 \%$, whereas the corresponding figure in the entire private sector was $12.4 \%{ }^{44}$ More union activity in manufacturing suggests that unions in manufacturing may be more experienced in identifying and organizing establishments that are more productive.

The model emphasizes union learning as a potential mechanism behind the unionization process. The age effects documented in the data are consistent with this mechanism. There may be alternative explanations for why age matters, though. For instance, unions may target younger businesses in part because management in such businesses may be inexperienced and less aware of union strategies. It may be easier for unions to organize such young businesses, as management opposition would be less intense, effectively lowering the cost of organizing and also potentially increasing the likelihood of win in a certification election.

The theory and empirics abstracted from establishment exit. Note, however, that the estimated probabilities of being a union establishment embed the effects of unions on exit likelihood. If, for instance, unionization increases the likelihood of exit, the estimated rate of unionization in the establishment population is lower than what it would be if unions had no effect on exit. These considerations, however, do not lead to empirical patterns that are inconsistent with the model's predictions. The analysis also assumed away union decertification. The rate of decertification in the population of unionized establishments is reflected in the estimated rate of unionization. Because decertifications are rare, they do not have a large effect on the overall rate of unionization, and the relationship between unionization and size, age, or productivity.

\section{Conclusion}

Despite the long presence of union activity in the U.S., there has been a lack of systematic evidence on which types of businesses unions target and when. A dynamic model of union learning and organizing is proposed to analyze the nature of union activity. A union monitors establishments in an industry to learn about their underlying unknown productivity over time.

\footnotetext{
${ }^{44}$ See the Union Membership and Coverage Database from the CPS at www.unionstats.com.
} 
Based on the learning process, it decides which firms are the most lucrative for organizing. The model predicts that the union tries to organize productive and larger establishments at any given age, and younger ones at any given size or productivity level. The benefits to organizing an establishment are increasing in its productivity because productive establishments can better provide high wages, large employment, better working conditions, and other benefits a union cares about. Establishment age matters because the union's information about productivity becomes more precise over time. Thus, the probability of obtaining a high level of benefits that occur in the right tail of the productivity distribution diminish. Conditional on size, an older establishment then generates lower expected benefit to the union, at least when benefits are convex in productivity. A convex benefit function emerges in a wide variety of models of firm-union conduct. The likelihood of being targeted by the union therefore declines with age, conditional on size. Furthermore, conditional on targeting an establishment, the union has a lower expected probability of winning a certification election when the establishment is more productive or larger.

The data on NLRB union elections matched with establishment characteristics from U.S. Census Bureau's LBD and EC data generally support the model's predictions. The main message is that there are clear selection effects in union organizing. First, unions tend to target large and productive establishments early in their life-cycles. Second, unions are also less likely to win certification elections in larger and more productive establishments. This second effect is dominated by the first one, resulting in a positive relationship between successful union organizing and productivity, as well as size. Size, age, and productivity effects appear to be more pronounced in the manufacturing sector, where unions have been traditionally stronger. The findings also support the model's view of unions as forward-looking agents which time their organizing efforts by weighing the future benefits against the current costs of organizing.

The selection of union activity into larger and more productive establishments has implications. First, studies concerned about the effect of unions on firm and establishment level outcomes must take into account this selection. Unionized establishments are not a random sample of the establishment population. To the extent that post-unionization outcomes depend on size and productivity around the time of unionization, this selection matters. Second, the effect of unions on the economy overall, and on its individual sectors, depend on the nature of this selection. For example, Schmitz (2005) suggests that unions may have adverse effects 
on firm productivity and output. To the extent that unions target more productive firms in an economy, these effects may be amplified. The decline of manufacturing could have been influenced by the presence of unions in larger and more productive establishments. Increasing global competition has been putting a downward pressure on profitability of all manufacturing establishments, but especially the larger ones that produce basic goods highly substitutable with imports, leading to their disappearance and downsizing. ${ }^{45}$ Whether unions have been able to extract rents from such establishments and reduce their profitability and survival likelihood, and hence have accelerated the decline in manufacturing, is an open question. For instance, Dinardo and Lee (2004) find little effect of unions on relatively large manufacturing establishments, a result that may be driven by the selection of unions into large, productive establishments, as documented here. These establishments may be able to withstand any adverse effects of unions on survival. Future work can quantify the effects of unions small versus large establishments using the comprehensive dataset constructed for this study. The decline in manufacturing itself may have led to fewer targets for unions and a decline in unionization, as larger establishments have gradually disappeared. The role of such effects in the decline of unionization can also be quantified. Finally, studies of unionization at the micro level can use the results and estimates in this paper as a guide in constructing models of the unionization process consistent with the patterns observed in the data.

\section{References}

[1] Alder, Simeon, Lagakos, David and Lee Ohanian. 2013. "The Decline of the U.S. Rust Belt: A Macroeconomic Analysis." Manuscript, Arizona State University.

[2] Brown, Charles, and Medoff, James L. (1989) "The Employer Size-Wage Effect", Journal of Political Economy, 97(5): 1027-1059.

[3] Brown, Charles, and Medoff, James L. (2003) "Firm Age and Wages", Journal of Labor Economics, 21(3): 677-698.

[4] Dinardo, John, and David Lee. 2004. "Economic Impacts of New Unionization on Private Sector Employers: 1984-2001", Quarterly Journal of Economics, 119(4): 1383-1441.

${ }^{45}$ See, for instance, Holmes (2011). 
[5] Dinlersoz, Emin and Jeremy Greenwood. 2013. "The Rise and Fall of Unions in the U.S." NBER working paper \#18079.

[6] Dinlersoz, Emin and Mehmet Yorukoglu. 2012. "Information and Industry Dynamics." American Economic Review, 102(2): 884-913.

[7] Dinlersoz, Emin and Ruben Hernandez-Murillo. 2002. "Did 'Right-to-Work' Work for Idaho?", The Federal Reserve Bank of St. Louis Review, May, pp. 29-42.

[8] Dunne, Tim, Roberts, Mark and Larry Samuelson. 1989. "The Growth And Failure Of U.S. Manufacturing Plants." Quarterly Journal of Economics, 104(4): 671-698.

[9] Farber, Henry and Bruce Western. 2001. "Accounting for the Decline of Unions in the Private Sector, 1973-1998." Journal of Labor Research, 22(3): 459-485.

[10] Ferguson, J. P. 2008. "The Eyes of the Needles: A Sequential Model of Union Organizing Drives, 1999 - 2004." Industrial and Labor Relations Review, 62(1): 1-18.

[11] Fishman, Arthur and Rafael Rob. 2002. "Consumer Inertia, Firm Growth and Industry Dynamics", Journal of Economic Theory, 109(1): 24-38.

[12] Foster, Lucia, Haltiwanger, John, and C. J. Krizan. 2001. "Aggregate Productivity Growth. Lessons from Microeconomic Evidence", in New Developments in Productivity Analysis, National Bureau of Economic Research, Inc.

[13] Freeman, Richard B. and James Medoff. 1984. What do Unions Do? Basic Books, New York.

[14] Frandsen, Brigham. 2013. "The Surprising Impacts of Unionization on Establishments: Accounting for Selection in Close Union Representation Elections", Manuscript. Department of Economics, Brigham Young University.

[15] Hadar, Josef and William R. Russell. 1971. "Stochastic Dominance and Diversification." Journal of Economic Theory, 3 (3): 288-305.

[16] Hirsch, Barry and David MacPherson. 2003. "Union Membership and Coverage Database from the Current Population Survey: Note." Industrial and Labor Relations Review, 56(2), 349-354. 
[17] Holmes, Thomas J. 1998. "The Effects of State Policies on the Location of Industry: Evidence from State Borders." Journal of Political Economy, 106 (4): 667-705.

[18] Holmes, Thomas J. 2006. "Geographic Spillover of Unionism." NBER Working Paper 12025, National Bureau of Economic Research, Inc.

[19] Holmes, Thomas J. 2011. "The Case of the Disappearing Large-Employer Manufacturing Plants: Not Much of a Mystery After All”, Economic Policy Paper 11-4, Federal Reserve Bank of Minneapolis.

[20] Jovanovic, Boyan. 1982. "Selection and the Evolution of Industry." Econometrica, 50 (3): 649-670.

[21] Karlin, Samuel and Herman Rubin. 1956. "The Theory of Decision Procedures for Distributions with Monotone Likelihood Ratio", Annals of Mathematical Statistics, 27 (2): 272-299.

[22] MacDonald, Glenn M. and Chris Robinson. 1992. "Unionism in a Competitive Industry." Journal of Labor Economics, 10 (1): 33-54.

[23] MacDonald, I. M., and Robert M. Solow. 1981. "Wage Bargaining and Employment." American Economic Review, 71: 896-908.

[24] Manning, Alan. 1987. "An Integration of Trade Union Models in a Sequential Bargaining Framework." The Economic Journal, 97: 121-139.

[25] Manning, Alan. 1994. "How Robust is the Microeconomic Theory of the Trade Union?." Journal of Labor Economics, 12(3): 430-458.

[26] Milgrom, Paul. 1981. "Good News and Bad News: Representation Theorems and Applications", The Bell Journal of Economics, 12(2): 380-391.

[27] Nickell, Stephen J. 1982. "A Bargaining Model of the Phillips Curve." LSE Centre for Labour Economics Discussion Paper.

[28] Oswald, A. J. 1982. "The Microeconomic Theory of the Trade Union." Economic Journal, 92: 269-283. 
[29] Schmitz, Jr, James A. 2005. "What Determines Productivity? Lessons From the Dramatic Recovery of the U.S. and Canadian Iron Ore Industries Following Their Early 1980s Crisis." Journal of Political Economy 113: 582-625.

[30] Stokey, Nancy L, and Robert E. Lucas. 1989. Recursive Methods in Economic Dynamics. Third Ed. Harvard University Press. Cambridge, MA.

[31] Taschereau-Dumouchel, Mathieu. 2011. "The Union Threat." Manuscript. The Wharton School, University of Pennsylvania.

[32] Voos, Paula. 1984. "Trends in Union Organizing Expenditures, 1953-1977." Industrial and Labor Relations Review, 38(1): 52-63. 
Figure 1. Information requested by UAW in online applications for union organizing (as of October 21, 2013)

\section{Contact UAW Organizing}

\section{Do you want to know more about joining the UAW?}

If so, we need some basic information so we can provide the best possible support and assistance to you and your co-workers.

\section{ALL INFORMATION IS CONFIDENTIAL!}

In order to respond all fields are required except those marked optional.

An organizer will contact you within the next ten business days. Thanks for your interest!

If you prefer, you can call the UAW Organizing Department at 1-800 2GET-UAW (1-800-243-8829). You'll be connected to (or get a call back from) a UAW organizer who can answer questions and tell you what it takes to organize a union at your workplace.

Your Name:

Your Address:

Your City:

Your State/Province: *

- Select -

Email Address: *

Phone: include area code: *

Cell Phone (optional):

Best time to return your call: *

\section{About the company}

Name of your employer: *

Parent company, if any (optional):

City: *

\section{State/Prov: *}

- Select -

Number of employees (best guess): * 
Figure 1. Continued.

Product or Service: *

The employer's main customers: *

Does your employer have more than one workplace?: *

Y Yes

- No

Are other workplaces owned by the employer organized by the UAW?: *

○ Yes

- No

Are other workplaces owned by the employer organized by another union?: *

Y Yes

- No

Is there another union involved at your workplace?: *

Yes

- No

Have there been previous attempts to organize at your workplace?: *

O Yes

- No

Please describe what needs to be improved at your workplace.: *

UAW Solidarity House | 8000 East Jefferson Avenue

Detroit, Michigan 48214 | p. (313) 926-5000

(C) Copyright 2013 UAW. All Rights Reserved. 
Figure 2. The union's timing of events and decisions for an age-a establishment
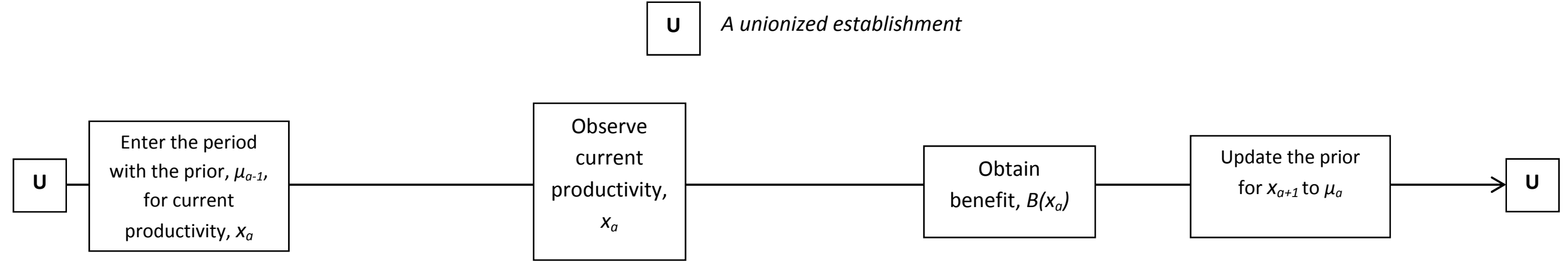

N A non-unionized establishment
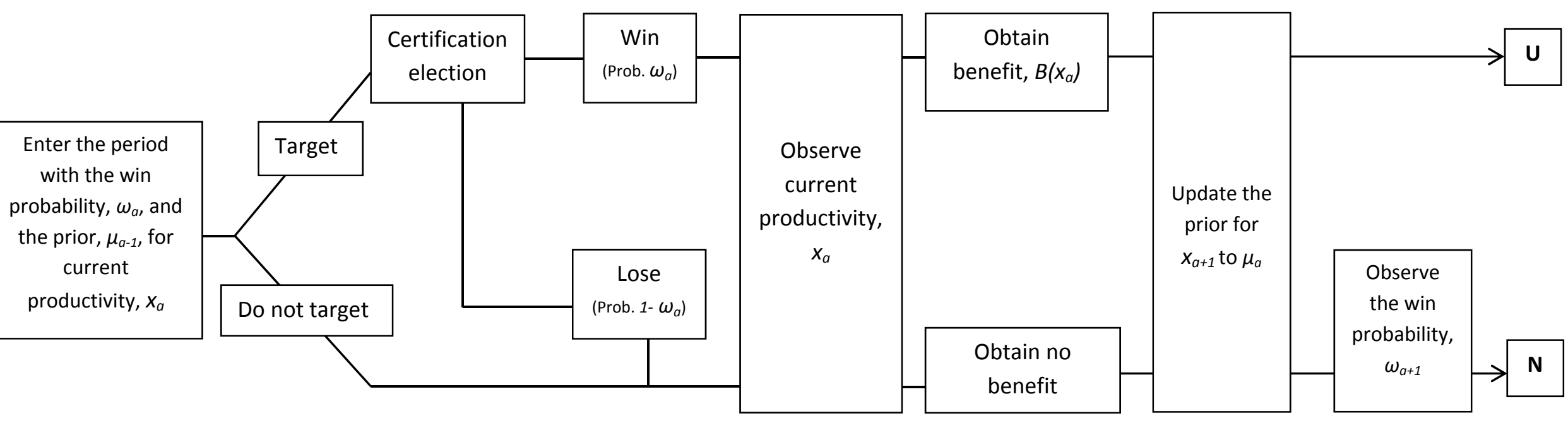
Figure 3. Predicted probabilities of union activity in manufacturing establishments -- Size, Age, and Year Effects

Size (Employment)

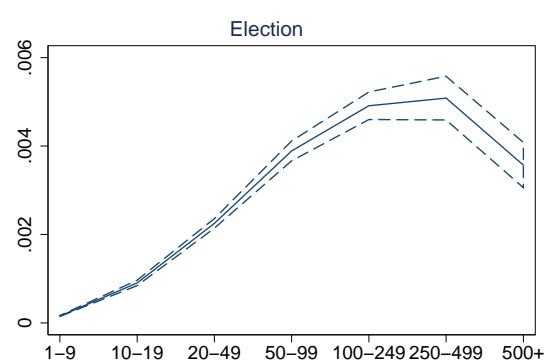

Election win
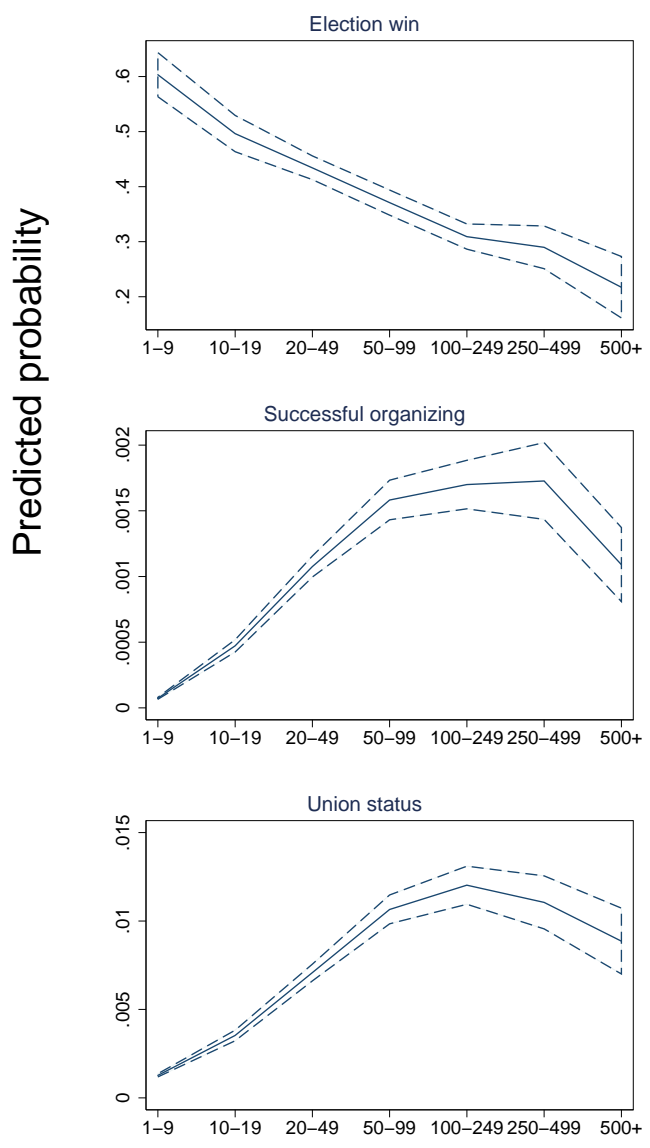

Employees
Size (Value of shipments)
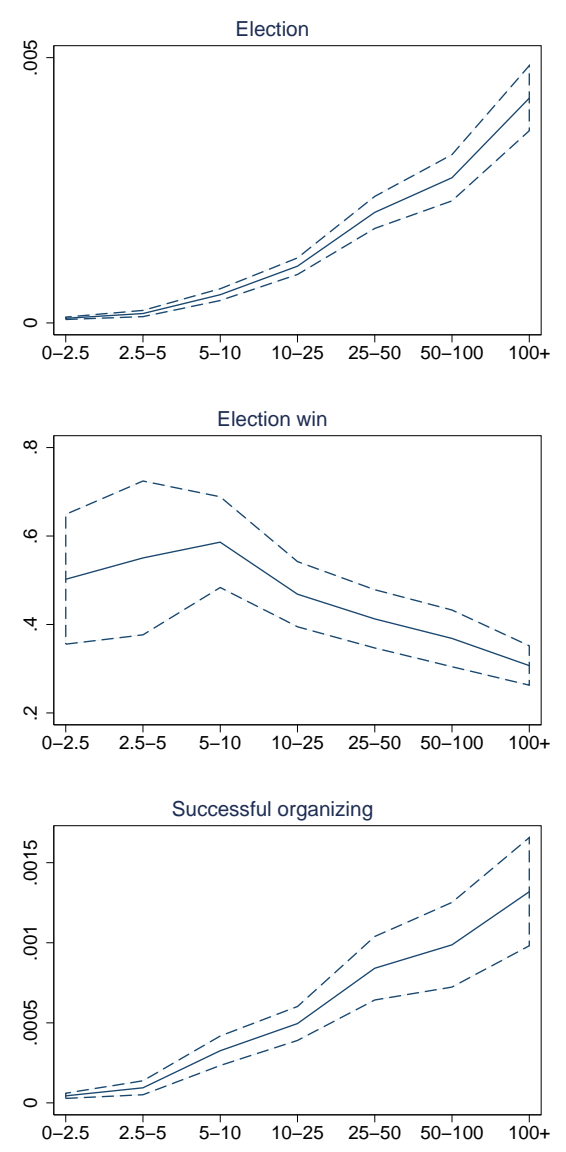

Union status

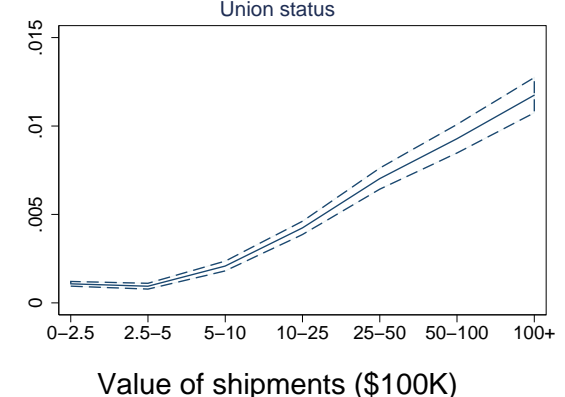

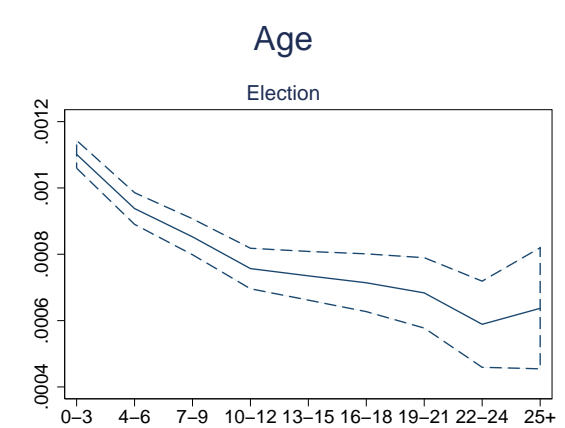
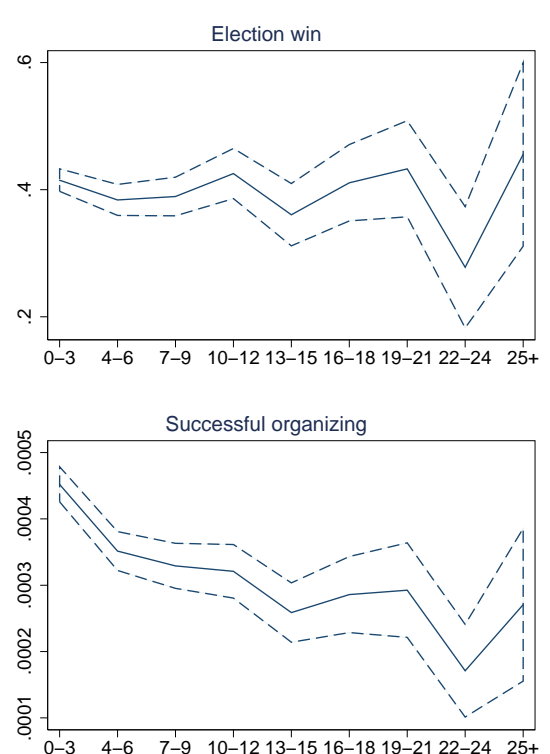

Union status

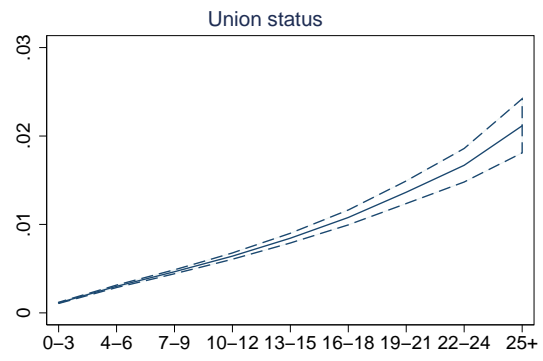

Age (years)
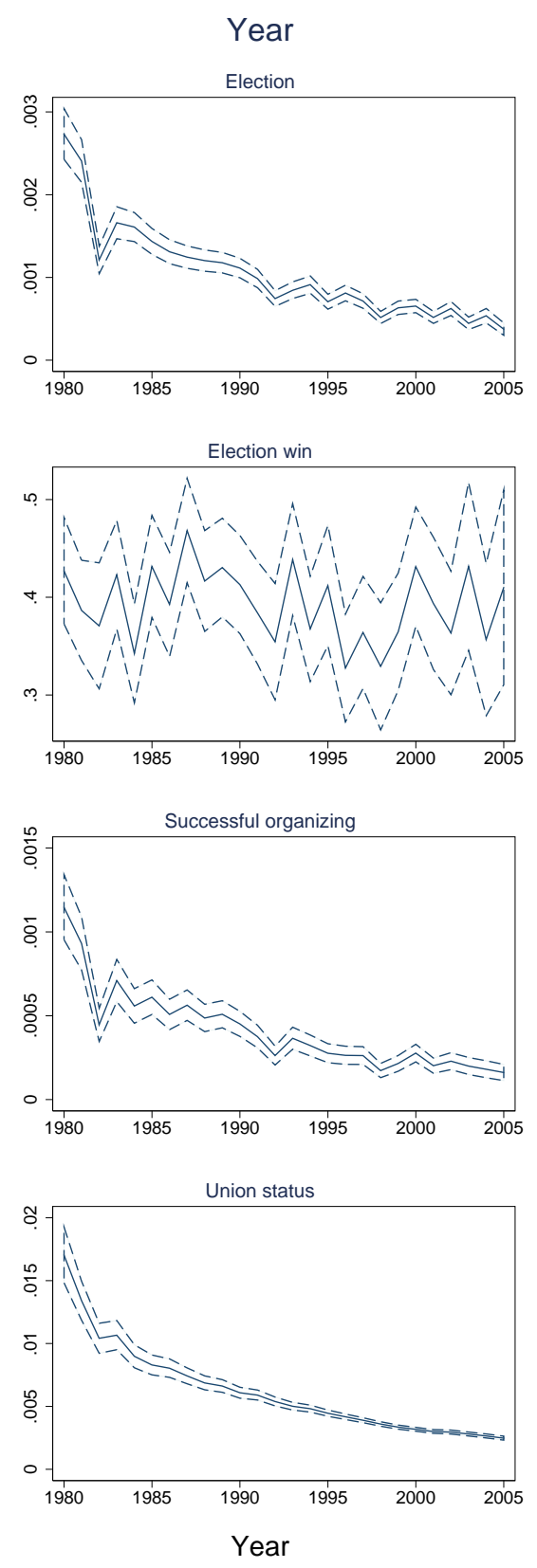

Note: Dashed curves indicate 95\% pointwise confidence intervals. 
Figure 4. Predicted probabilities of union activity in private sector establishments -- Size, Age, and Year Effects Size (Employment)
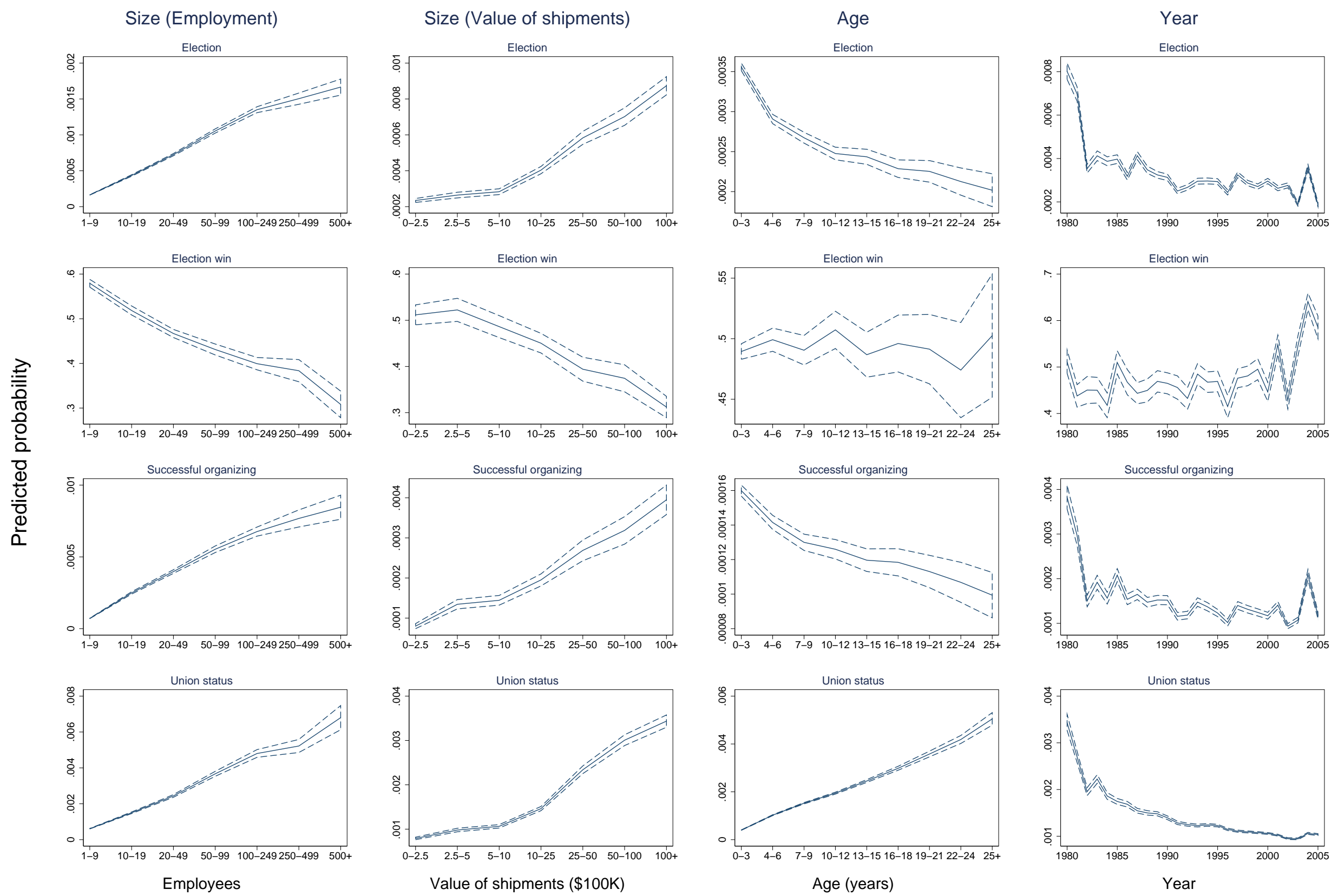

Note: Dashed curves indicate 95\% pointwise confidence intervals. 
Figure 5. Predicted probabilities of union activity in manufacturing establishments -- Productivity effects

Value of shipments per employee

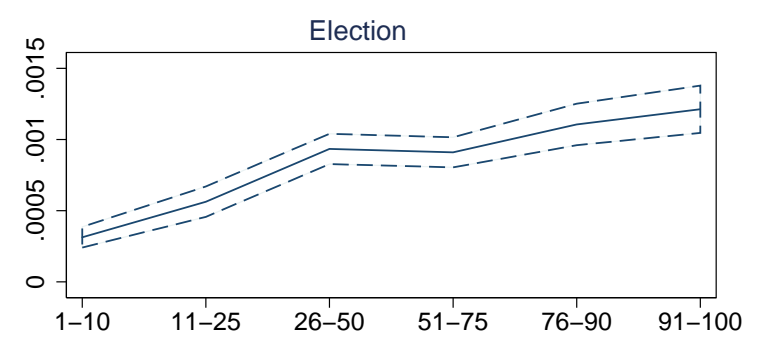

Election win

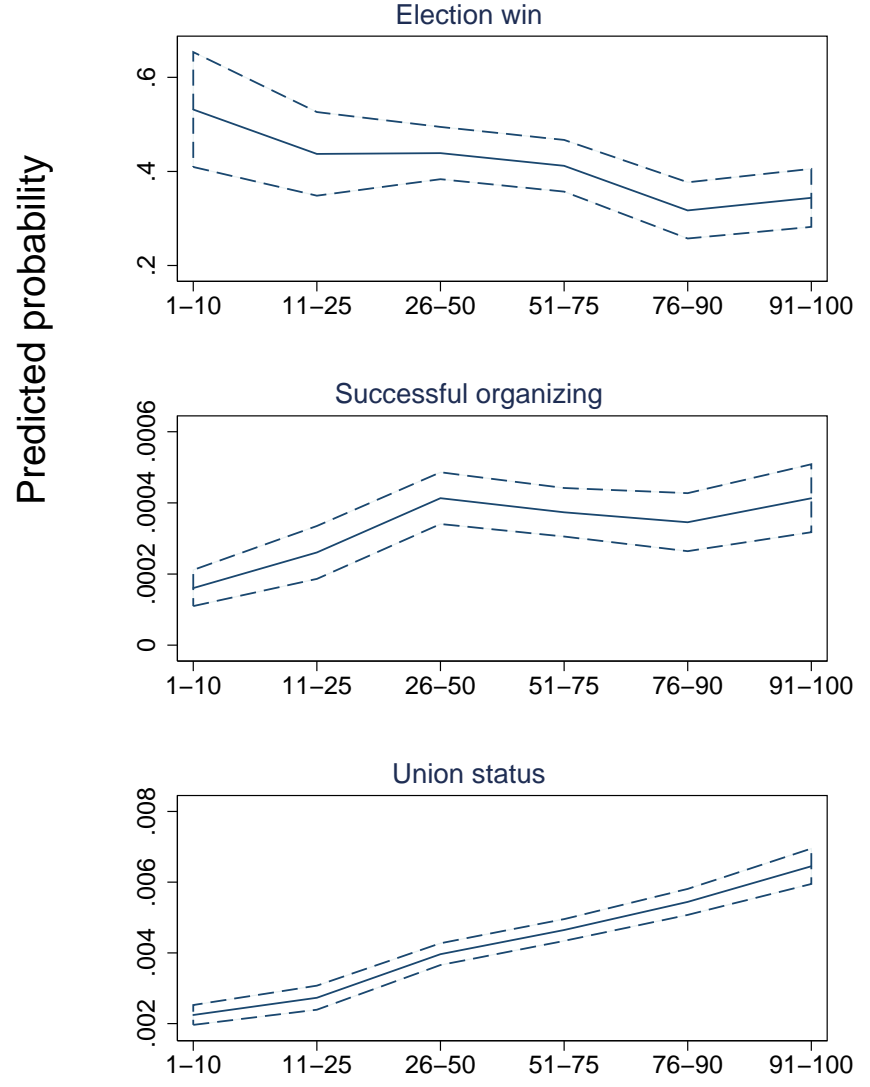

Value added per employee

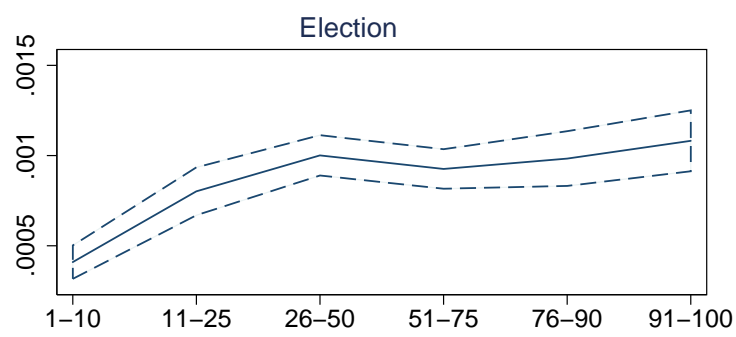

Election win
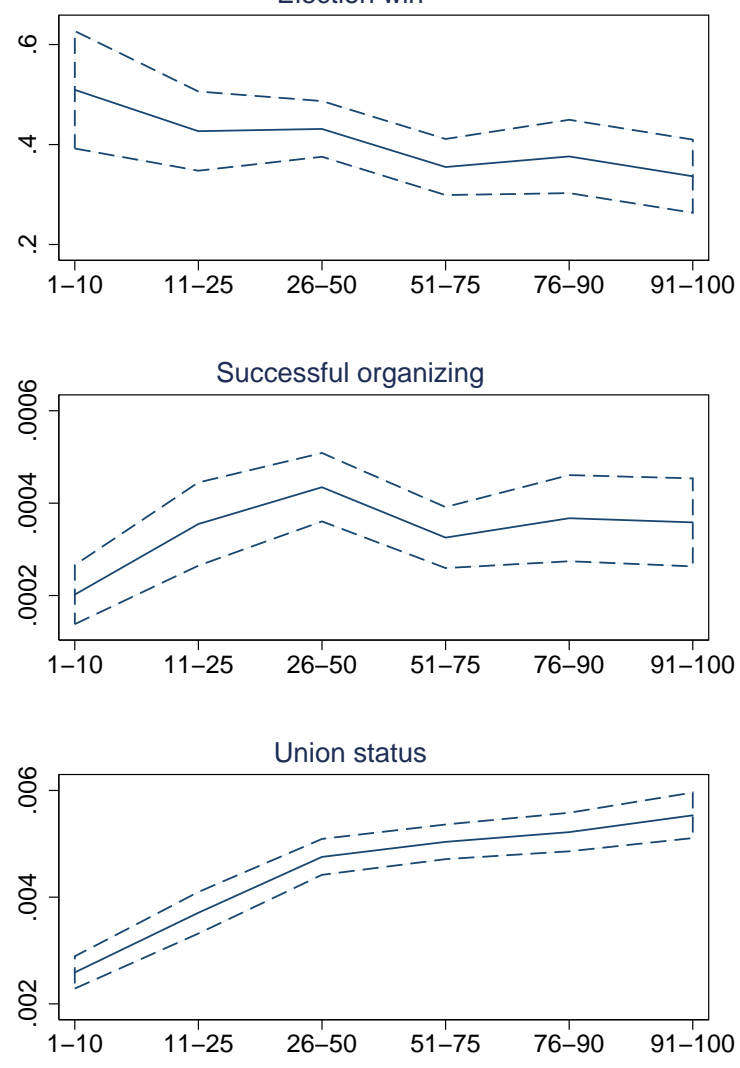

Productivity percentile
Total factor productivity
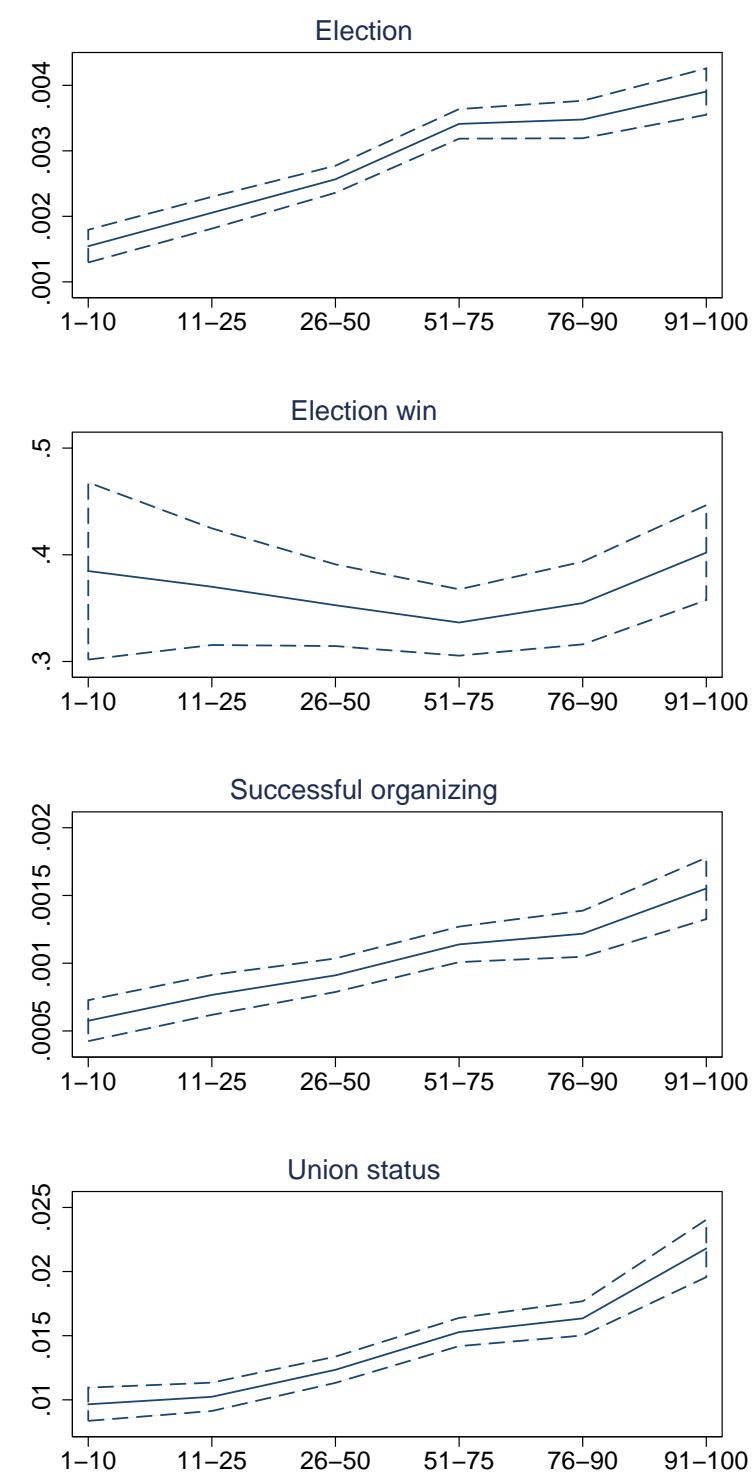

Note: Dashed curves indicate $95 \%$ pointwise confidence intervals. 
Figure 6. Predicted probabilities of union activity in private sector establishments -- Productivity effects
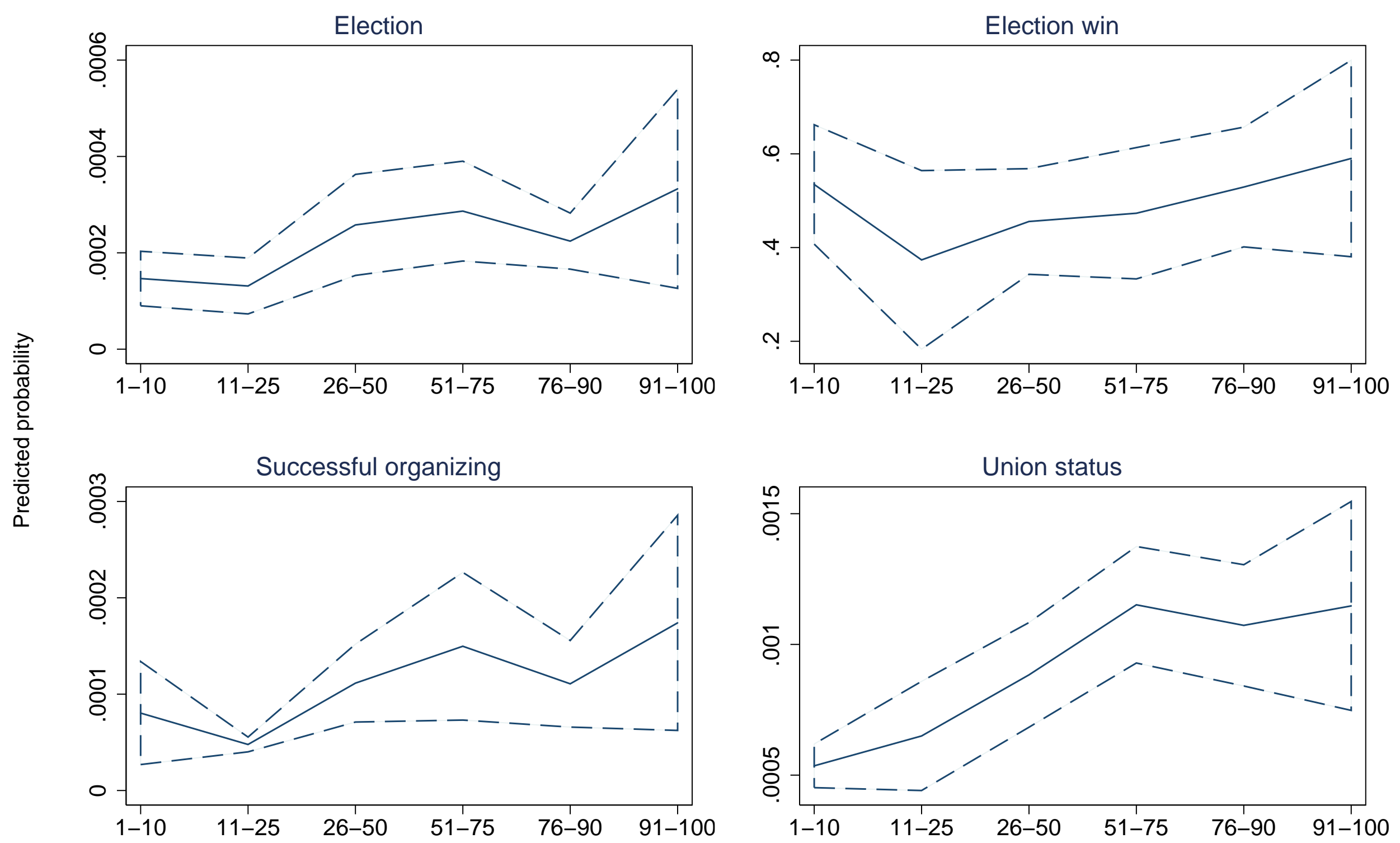

Percentiles of value of shipments per employee

Note: Dashed curves indicate $95 \%$ pointwise confidence intervals. 
TABLE 1. Odds ratios based on logit model estimates - All Sectors

\begin{tabular}{|c|c|c|c|c|}
\hline \multirow{3}{*}{$\begin{array}{l}\text { Event: } \\
\text { Probability: }\end{array}$} & \multicolumn{2}{|c|}{ Certification: } & \multirow{3}{*}{$\begin{array}{l}\text { Successful } \\
\text { Organizing } \\
O^{o}\left(x_{a}, a\right)\end{array}$} & \multirow{3}{*}{$\begin{array}{l}\text { Union } \\
\text { Status } \\
U^{o}\left(x_{a}, a\right)\end{array}$} \\
\hline & Election & Win & & \\
\hline & $T^{o}\left(x_{a}, a\right)$ & $W^{o}\left(x_{a}, a\right)$ & & \\
\hline 10-19 employees & $\begin{array}{l}2.66^{* * *} \\
{[0.038]}\end{array}$ & $\begin{array}{l}0.75^{* * *} \\
{[0.023]}\end{array}$ & $\begin{array}{l}3.48^{* * *} \\
{[0.074]}\end{array}$ & $\begin{array}{l}2.46^{* * *} \\
{[0.043]}\end{array}$ \\
\hline 20-49 employees & $\begin{array}{l}4.44^{* * *} \\
{[0.063]}\end{array}$ & $\begin{array}{l}0.59^{* * *} \\
{[0.019]}\end{array}$ & $\begin{array}{l}5.56^{* * *} \\
{[0.118]}\end{array}$ & $\begin{array}{l}4.02^{* * *} \\
{[0.080]}\end{array}$ \\
\hline 50-99 employees & $\begin{array}{l}6.46^{* * *} \\
{[0.109]}\end{array}$ & $\begin{array}{l}0.49^{* * *} \\
{[0.019]}\end{array}$ & $\begin{array}{l}7.73^{* * *} \\
{[0.198]}\end{array}$ & $\begin{array}{l}6.11^{* * *} \\
{[0.143]}\end{array}$ \\
\hline 100-249 employees & $\begin{array}{l}8.29^{* * *} \\
{[0.152]}\end{array}$ & $\begin{array}{l}0.43^{* * *} \\
{[0.018]}\end{array}$ & $\begin{array}{l}9.46^{* * *} \\
{[0.226]}\end{array}$ & $\begin{array}{l}8.04^{* * *} \\
{[0.215]}\end{array}$ \\
\hline 250-499 employees & $\begin{array}{l}9.25^{* * *} \\
{[0.263]}\end{array}$ & $\begin{array}{l}0.39^{* * *} \\
{[0.027]}\end{array}$ & $\begin{array}{l}10.74^{* * *} \\
{[0.455]}\end{array}$ & $\begin{array}{l}8.75^{* * *} \\
{[0.341]}\end{array}$ \\
\hline $500+$ employees & $\begin{array}{l}10.24^{* * *} \\
{[0.366]}\end{array}$ & $\begin{array}{l}0.27^{* * *} \\
{[0.024]}\end{array}$ & $\begin{array}{l}11.84^{* * *} \\
{[0.628]}\end{array}$ & $\begin{array}{l}11.49^{* * *} \\
{[0.624]}\end{array}$ \\
\hline 4-6 years & $\begin{array}{l}0.82^{* * *} \\
{[0.010]}\end{array}$ & ${ }_{[0.046]}^{1.04}$ & $\begin{array}{l}0.88^{* * *} \\
{[0.016]}\end{array}$ & $\begin{array}{l}2.58^{* * *} \\
{[0.023]}\end{array}$ \\
\hline 7-9 years & $\begin{array}{l}0.75^{* * *} \\
{[0.011]}\end{array}$ & $\begin{array}{l}1.00 \\
{[0.033]}\end{array}$ & $\begin{array}{l}0.81^{* * *} \\
{[0.017]}\end{array}$ & $\begin{array}{l}3.85^{* * *} \\
{[0.046]}\end{array}$ \\
\hline 10-12 years & $\begin{array}{l}0.69^{* * *} \\
{[0.012]}\end{array}$ & ]$_{[0.043]}^{1.09}$ & $\begin{array}{l}0.78^{* * *} \\
{[0.019]}\end{array}$ & $\begin{array}{l}4.94^{* * *} \\
{[0.069]}\end{array}$ \\
\hline 13-15 years & $\begin{array}{l}0.68^{* * *} \\
{[0.014]}\end{array}$ & $\begin{array}{c}0.98 \\
{[0.046]}\end{array}$ & $\begin{array}{l}0.75^{* * *} \\
{[0.022]}\end{array}$ & $\begin{array}{l}6.26^{* * *} \\
{[0.100]}\end{array}$ \\
\hline 16-18 years & $\begin{array}{l}0.64^{* * *} \\
{[0.016]}\end{array}$ & $\begin{array}{c}1.03 \\
{[0.060]}\end{array}$ & $\begin{array}{l}0.74^{* * *} \\
{[0.026]}\end{array}$ & $\begin{array}{l}7.65^{* * *} \\
{[0.139]}\end{array}$ \\
\hline $19-21$ years & $\begin{array}{l}0.63^{* * *} \\
{[0.020]}\end{array}$ & $\begin{array}{c}1.01 \\
{[0.071]}\end{array}$ & $\begin{array}{l}0.71^{* * *} \\
{[0.031]}\end{array}$ & $\begin{array}{l}9.22^{* * *} \\
{[0.191]}\end{array}$ \\
\hline $22-24$ years & $\begin{array}{l}0.59^{* * *} \\
{[0.024]}\end{array}$ & $\begin{array}{c}0.93 \\
{[0.088]}\end{array}$ & $\begin{array}{l}0.67^{* * *} \\
{[0.038]}\end{array}$ & $\begin{array}{l}10.84^{* * *} \\
{[0.263]}\end{array}$ \\
\hline $25+$ years & $\begin{array}{l}0.57^{* * *} \\
{[0.029]}\end{array}$ & $\begin{array}{c}1.06 \\
{[0.129]}\end{array}$ & $\begin{array}{l}0.62^{* * *} \\
{[0.043]}\end{array}$ & $\begin{array}{l}13.17^{* * *} \\
{[0.400]}\end{array}$ \\
\hline Multi-unit status & $\begin{array}{l}4.92^{* * *} \\
{[0.063]}\end{array}$ & $\begin{array}{l}0.44^{* * *} \\
{[0.012]}\end{array}$ & $\begin{array}{l}3.29^{* * *} \\
{[0.061]}\end{array}$ & $\begin{array}{l}3.05^{* * *} \\
{[0.063]}\end{array}$ \\
\hline Firm union status & $\begin{array}{l}3.40^{* * *} \\
{[0.029]}\end{array}$ & $\begin{array}{l}5.45^{* * *} \\
{[0.142]}\end{array}$ & $\begin{array}{l}5.51^{* * *} \\
{[0.062]}\end{array}$ & $\begin{array}{l}5.04^{* * *} \\
{[0.063]}\end{array}$ \\
\hline Right-to-work status & $\begin{array}{l}0.88^{*} \\
{[0.054]}\end{array}$ & $\begin{array}{c}0.89 \\
{[0.106]}\end{array}$ & $\begin{array}{l}0.83^{*} \\
{[0.051]}\end{array}$ & $\begin{array}{c}0.93 \\
{[0.051]}\end{array}$ \\
\hline Eligible employees \% & - & $\begin{array}{l}0.755^{* * *} \\
{[0.005]}\end{array}$ & - & - \\
\hline
\end{tabular}

Notes: Robust standard errors, clustered by establishment, are in brackets. $(*),(* *),(* * *)$ indicate significance at $10 \%, 5 \%, 1 \%$, respectively. Models include 2-digit SIC industry, state, and year fixed effects. The following categories are omitted: 1-9 employees and 0-3 years of age. 
TABLE 2. Odds ratios based on logit model estimates - Manufacturing

\begin{tabular}{|c|c|c|c|c|}
\hline \multirow{3}{*}{$\begin{array}{l}\text { Event: } \\
\text { Probability: }\end{array}$} & \multicolumn{2}{|c|}{ Certification: } & \multirow{3}{*}{$\begin{array}{l}\text { Successful } \\
\text { Organizing } \\
O^{o}\left(x_{a}, a\right)\end{array}$} & \multirow{3}{*}{$\begin{array}{l}\text { Union } \\
\text { Status } \\
U^{o}\left(x_{a}, a\right) \\
\end{array}$} \\
\hline & Election & Win & & \\
\hline & $T^{o}\left(x_{a}, a\right)$ & $W^{o}\left(x_{a}, a\right)$ & & \\
\hline 10-19 employees & $\begin{array}{l}5.79^{* * *} \\
{[0.290]}\end{array}$ & $\begin{array}{l}0.63^{* * *} \\
{[0.070]}\end{array}$ & $\begin{array}{l}6.46^{* * *} \\
{[0.475]}\end{array}$ & $\begin{array}{l}2.78^{* * *} \\
{[0.132]}\end{array}$ \\
\hline 20-49 employees & $\begin{array}{l}14.45^{* * *} \\
{[0.663]}\end{array}$ & $\begin{array}{l}0.49^{* * *} \\
{[0.050]}\end{array}$ & $\begin{array}{l}14.75^{* * *} \\
{[1.014]}\end{array}$ & $\begin{array}{l}5.65^{* * *} \\
{[0.280]}\end{array}$ \\
\hline 50-99 employees & $\begin{array}{l}25.05^{* * *} \\
{[1.265]}\end{array}$ & $\begin{array}{l}0.37^{* * *} \\
{[0.040]}\end{array}$ & $\begin{array}{l}21.73^{* * *} \\
{[1.691]}\end{array}$ & $\begin{array}{l}8.58^{* * *} \\
{[0.489]}\end{array}$ \\
\hline 100-249 employees & $\begin{array}{l}31.69^{* * *} \\
{[1.692]}\end{array}$ & $\begin{array}{l}0.28^{* * *} \\
{[0.031]}\end{array}$ & $\begin{array}{l}23.35^{* * *} \\
{[1.954]}\end{array}$ & $\begin{array}{l}9.72^{* * *} \\
{[0.619]}\end{array}$ \\
\hline 250-499 employees & $\begin{array}{l}32.82^{* * *} \\
{[2.163]}\end{array}$ & $\begin{array}{l}0.25^{* * *} \\
{[0.036]}\end{array}$ & $\begin{array}{l}23.72^{* * *} \\
{[2.548]}\end{array}$ & $\begin{array}{l}8.91^{* * *} \\
{[0.743]}\end{array}$ \\
\hline $500+$ employees & $\begin{array}{l}22.98^{* * *} \\
{[1.964]}\end{array}$ & $\begin{array}{l}0.17^{\text {*** }} \\
{[0.035]}\end{array}$ & $\begin{array}{l}14.96^{* * *} \\
{[2.194]}\end{array}$ & $\begin{array}{l}7.11^{* * *} \\
{[0.838]}\end{array}$ \\
\hline 4-6 years & $\begin{array}{l}0.85^{* * *} \\
{[0.028]}\end{array}$ & $\begin{array}{l}0.87^{* *} \\
{[0.060]}\end{array}$ & $\begin{array}{l}0.78^{* * *} \\
{[0.040]}\end{array}$ & $\begin{array}{l}2.68^{* * *} \\
{[0.681]}\end{array}$ \\
\hline 7-9 years & $\begin{array}{l}0.77^{* * *} \\
{[0.030]}\end{array}$ & $\begin{array}{c}0.89 \\
{[0.073]}\end{array}$ & $\begin{array}{l}0.73^{* * *} \\
{[0.046]}\end{array}$ & $\begin{array}{l}4.18^{* * *} \\
{[0.152]}\end{array}$ \\
\hline 10-12 years & $\begin{array}{l}0.68^{* * *} \\
{[0.032]}\end{array}$ & ${ }_{[0.103]}{ }^{*}$ & $\begin{array}{l}0.71^{* * *} \\
{[0.052]}\end{array}$ & $\begin{array}{l}5.83^{* * *} \\
{[0.256]}\end{array}$ \\
\hline $13-15$ years & $\begin{array}{l}0.66^{* * *} \\
{[0.035]}\end{array}$ & $\begin{array}{l}0.78^{* *} \\
{[0.097]}\end{array}$ & $\begin{array}{l}0.57^{* * *} \\
{[0.055]}\end{array}$ & $\begin{array}{l}7.75^{* * *} \\
{[0.393]}\end{array}$ \\
\hline 16-18 years & $\begin{array}{l}0.64^{* * *} \\
{[0.043]}\end{array}$ & $\begin{array}{c}0.98 \\
{[0.140]}\end{array}$ & $\begin{array}{l}0.63^{* * *} \\
{[0.069]}\end{array}$ & $\begin{array}{l}10.02^{* * *} \\
{[0.583]}\end{array}$ \\
\hline 19-21 years & $\begin{array}{l}0.62^{* * *} \\
{[0.052]}\end{array}$ & $\begin{array}{l}1.08 \\
{[0.188]}\end{array}$ & $\begin{array}{l}0.64^{* * *} \\
{[0.084]}\end{array}$ & $\begin{array}{l}12.84^{* * *} \\
{[0.861]}\end{array}$ \\
\hline $22-24$ years & $\begin{array}{l}0.53^{* * *} \\
{[0.062]}\end{array}$ & $\begin{array}{l}0.52^{* *} \\
{[0.136]}\end{array}$ & $\begin{array}{l}0.38^{* * *} \\
{[0.080]}\end{array}$ & $\begin{array}{l}15.94^{* * *} \\
{[1.248]}\end{array}$ \\
\hline $25+$ years & $\begin{array}{l}0.57^{* * *} \\
{[0.086]}\end{array}$ & $\begin{array}{c}1.19 \\
{[0.379]}\end{array}$ & $\begin{array}{l}0.59^{* * *} \\
{[0.132]}\end{array}$ & $\begin{array}{l}20.62^{* * *} \\
{[1.969]}\end{array}$ \\
\hline Multi-unit status & $\begin{array}{l}2.09^{* * *} \\
{[0.067]}\end{array}$ & $\begin{array}{l}0.78^{* * *} \\
{[0.043]}\end{array}$ & $\begin{array}{l}1.92^{* * *} \\
{[0.095]}\end{array}$ & $\begin{array}{l}2.78^{* * *} \\
{[0.143]}\end{array}$ \\
\hline Firm-union status & $\begin{array}{l}2.01^{* * *} \\
{[0.066]}\end{array}$ & $\begin{array}{l}2.16^{* * *} \\
{[0.156]}\end{array}$ & $\begin{array}{l}2.82^{* * *} \\
{[0.136]}\end{array}$ & $2^{2.84^{0.109]}}{ }^{* *}$ \\
\hline Right-to-work status & $\begin{array}{c}0.85 \\
{[0.112]}\end{array}$ & $\begin{array}{c}0.98 \\
{[0.274]}\end{array}$ & $\begin{array}{c}0.83 \\
{[0.177]}\end{array}$ & $\begin{array}{c}0.99 \\
{[0.110]}\end{array}$ \\
\hline Eligible employees \% & - & $\begin{array}{l}0.78^{* * *} \\
{[0.017]}\end{array}$ & - & - \\
\hline
\end{tabular}

Notes: Robust standard errors, clustered by establishment, are in brackets. $(*),(* *),(* * *)$ indicate significance at $10 \%, 5 \%, 1 \%$, respectively. Models include 2-digit SIC industry, state, and year fixed effects.

The following categories are omitted: 1-9 employees and 0-3 years of age. 
TABLE 3. Odds ratios based on logit model estimates

\begin{tabular}{|c|c|c|c|c|}
\hline \multirow[t]{2}{*}{ Event: } & \multicolumn{2}{|c|}{ Certification: } & \multirow{2}{*}{$\begin{array}{l}\text { Successful } \\
\text { Organizing }\end{array}$} & \multirow{2}{*}{$\begin{array}{l}\text { Union } \\
\text { Status }\end{array}$} \\
\hline & Election & Win & & \\
\hline Probability: & $T^{o}\left(x_{a}, a\right)$ & $W^{o}\left(x_{a}, a\right)$ & $O^{o}\left(x_{a}, a\right)$ & $U^{o}\left(x_{a}, a\right)$ \\
\hline \multicolumn{5}{|c|}{ All Sectors (Value of Shipments) } \\
\hline$\$ 250-500 \mathrm{~K}$ & $\begin{array}{l}1.13^{* * *} \\
{[0.042]}\end{array}$ & $\begin{array}{l}1.06 \\
{[0.085]}\end{array}$ & $\begin{array}{l}1.68^{* * *} \\
{[0.097]}\end{array}$ & $\begin{array}{l}1.24^{* * *} \\
{[0.029]}\end{array}$ \\
\hline$\$ 500 \mathrm{~K}-1 \mathrm{M}$ & $\begin{array}{l}1.21^{* * *} \\
{[0.047]}\end{array}$ & $\begin{array}{l}0.87^{*} \\
{[0.072]}\end{array}$ & $\begin{array}{l}1.81^{* * *} \\
{[0.111]}\end{array}$ & $\begin{array}{l}1.35^{* * *} \\
{[0.034]}\end{array}$ \\
\hline$\$ 1 \mathrm{M}-2.5 \mathrm{M}$ & ${ }_{[0.066]}^{1.72^{* *}}$ & $\begin{array}{l}0.73^{* * *} \\
{[0.060]}\end{array}$ & $\begin{array}{l}2.44^{* * *} \\
{[0.151]}\end{array}$ & $\begin{array}{l}1.86^{* * *} \\
{[0.047]}\end{array}$ \\
\hline$\$ 2.5-5 \mathrm{M}$ & $\begin{array}{l}2.49^{* * *} \\
{[0.107]}\end{array}$ & $\begin{array}{l}0.54^{* * *} \\
{[0.053]}\end{array}$ & $\begin{array}{l}3.37^{* * *} \\
{[0.234]}\end{array}$ & $\begin{array}{l}2.99^{* * *} \\
{[0.084]}\end{array}$ \\
\hline$\$ 5-10 \mathrm{M}$ & $\begin{array}{l}3.00^{* * *} \\
{[0.138]}\end{array}$ & $\begin{array}{l}0.49^{* * *} \\
{[0.052]}\end{array}$ & $\begin{array}{l}3.99^{* * *} \\
{[0.298]}\end{array}$ & $\begin{array}{l}3.87^{* * *} \\
{[0.116]}\end{array}$ \\
\hline$\$ 10 \mathrm{M}+$ & $\begin{array}{l}3.74^{* * *} \\
{[0.160]}\end{array}$ & $\begin{array}{l}0.34^{* * *} \\
{[0.036]}\end{array}$ & $\begin{array}{l}4.95^{* * *} \\
{[0.350]}\end{array}$ & $\begin{array}{l}4.43^{* * *} \\
{[0.135]}\end{array}$ \\
\hline \multicolumn{5}{|c|}{ Manufacturing (Value of shipments) } \\
\hline$\$ 250-500 \mathrm{~K}$ & $\begin{array}{l}2.03^{* * *} \\
{[0.428]}\end{array}$ & $\begin{array}{l}1.23 \\
{[0.603]}\end{array}$ & ${ }^{2.14^{* * * *}}$ & $\begin{array}{c}0.87 \\
{[0.088]}\end{array}$ \\
\hline$\$ 500 \mathrm{~K}-1 \mathrm{M}$ & $\begin{array}{l}6.09^{* * *} \\
{[1.034]}\end{array}$ & $\begin{array}{l}1.43 \\
{[0.555]}\end{array}$ & $\begin{array}{l}7.38^{* * *} \\
{[1.744]}\end{array}$ & $\begin{array}{l}1.94^{* * *} \\
{[0.166]}\end{array}$ \\
\hline$\$ 1 \mathrm{M}-2.5 \mathrm{M}$ & $\begin{array}{l}12.24^{* * *} \\
{[1.915]}\end{array}$ & $\begin{array}{l}0.87 \\
{[0.308]}\end{array}$ & $\begin{array}{l}11.24^{* * *} \\
{[2.526]}\end{array}$ & $\begin{array}{l}3.96^{* * *} \\
{[0.300]}\end{array}$ \\
\hline$\$ 2.5-5 \mathrm{M}$ & $\begin{array}{l}23.89^{* * *} \\
{[3.856]}\end{array}$ & $\begin{array}{c}0.68 \\
{[0.237]}\end{array}$ & $\begin{array}{l}19.08^{* * *} \\
{[4.605]}\end{array}$ & $\begin{array}{l}6.61^{* * *} \\
{[0.522]}\end{array}$ \\
\hline$\$ 5-10 \mathrm{M}$ & $\begin{array}{l}31.42^{* * *} \\
{[5.315]}\end{array}$ & $\begin{array}{l}0.56^{*} \\
{[0.196]}\end{array}$ & $\begin{array}{l}22.42^{* * *} \\
{[5.762]}\end{array}$ & $\begin{array}{l}8.78^{* * *} \\
{[0.731]}\end{array}$ \\
\hline$\$ 10 \mathrm{M}+$ & $\begin{array}{l}48.78^{* * * *} \\
{[8.374]}\end{array}$ & $\begin{array}{l}0.42^{* * *} \\
{[0.141]}\end{array}$ & $\begin{array}{l}29.97^{* * *} \\
{[7.900]}\end{array}$ & $\begin{array}{l}11.18^{* * *} \\
{[0.959]}\end{array}$ \\
\hline
\end{tabular}

Notes: Robust standard errors, clustered by establishment, are in brackets. $(*),(* *),(* * *)$ indicate

significance at $10 \%, 5 \%, 1 \%$, respectively. Models include all other explanatory variables

in Tables 1 and 2. The following categories are omitted: $\$ 0-250 \mathrm{~K}$ value of shipments and $0-3$ years of age.. 
TABLE 4. Odds ratios based on logit model estimates

\begin{tabular}{|c|c|c|c|c|}
\hline \multirow{3}{*}{$\begin{array}{l}\text { Event: } \\
\text { Probability: }\end{array}$} & \multicolumn{2}{|c|}{ Certification: } & \multirow{3}{*}{$\begin{array}{l}\text { Successful } \\
\text { Organizing } \\
O^{o}\left(x_{a}, a\right)\end{array}$} & \multirow{3}{*}{$\begin{array}{l}\text { Union } \\
\text { Status } \\
U^{o}\left(x_{a}, a\right)\end{array}$} \\
\hline & Election & Win & & \\
\hline & $T^{o}\left(x_{a}, a\right)$ & $W^{o}\left(x_{a}, a\right)$ & & \\
\hline \multicolumn{5}{|c|}{ All Sectors (Value of shipments per employee) } \\
\hline 11-25 percentile & $\begin{array}{c}0.89 \\
{[0.255]}\end{array}$ & $\begin{array}{l}0.46^{*} \\
{[0.203]}\end{array}$ & $\begin{array}{c}0.59 \\
{[0.203]}\end{array}$ & $\begin{array}{c}1.21 \\
{[0.213]}\end{array}$ \\
\hline 26-50 percentile & $1_{[0.461]}$ & $\begin{array}{c}0.68 \\
{[0.237]}\end{array}$ & $\begin{array}{l}1.39 \\
{[0.530]}\end{array}$ & $\begin{array}{l}1.66^{* * *} \\
{[0.215]}\end{array}$ \\
\hline $51-75$ percentile & ${ }_{[0.511]}$ & $\begin{array}{c}0.74 \\
{[0.313]}\end{array}$ & $\begin{array}{c}1.86 \\
{[0.752]}\end{array}$ & $2^{2.16^{* * *}}$ \\
\hline 76-90 percentile & $\begin{array}{l}1.53^{*} \\
{[0.359]}\end{array}$ & $\begin{array}{c}0.97 \\
{[0.421]}\end{array}$ & $\begin{array}{c}1.38 \\
{[0.537]}\end{array}$ & $\begin{array}{l}2.01^{* * *} \\
{[0.246]}\end{array}$ \\
\hline 91-100 percentile & $\begin{array}{l}2.27^{* *} \\
{[0.802]}\end{array}$ & $\begin{array}{c}1.32 \\
{[0.781]} \\
\end{array}$ & $\begin{array}{l}2.16^{*} \\
{[0.984]}\end{array}$ & $\begin{array}{l}2.15^{* * *} \\
{[0.384]}\end{array}$ \\
\hline \multicolumn{5}{|c|}{ Manufacturing (Value of shipments per employee) } \\
\hline 11-25 percentile & $\begin{array}{l}1.80^{* * *} \\
{[0.274]}\end{array}$ & $\begin{array}{c}0.66 \\
{[0.221]}\end{array}$ & $1.62^{* *}$ & $1.22^{* *}$ \\
\hline 26-50 percentile & $\begin{array}{l}2.98^{* * *} \\
{[0.393]}\end{array}$ & $\begin{array}{c}0.67 \\
{[0.199]}\end{array}$ & $\begin{array}{l}2.57^{* * *} \\
{[0.479]}\end{array}$ & $\begin{array}{l}1.78^{* * *} \\
{[0.132]}\end{array}$ \\
\hline $51-75$ percentile & ${ }_{[0.988]}^{* * *}$ & $\begin{array}{l}0.59^{*} \\
{[0.176]}\end{array}$ & $\begin{array}{l}2.31^{* * *} \\
{[0.438]}\end{array}$ & $\begin{array}{l}2.09^{* * *} \\
{[0.150]}\end{array}$ \\
\hline 76-90 percentile & $\begin{array}{l}3.54^{* * *} \\
{[0.485]}\end{array}$ & $\begin{array}{l}0.38^{* * *} \\
{[0.118]}\end{array}$ & $\begin{array}{l}2.15^{* * *} \\
{[0.435]}\end{array}$ & $\begin{array}{l}2.46^{* * *} \\
{[0.177]}\end{array}$ \\
\hline 91-100 percentile & $\begin{array}{l}3.88^{* * *} \\
{[0.534]} \\
\end{array}$ & $\begin{array}{l}0.43^{* * *} \\
{[0.135]}\end{array}$ & $\begin{array}{l}2.57^{* * *} \\
{[0.506]}\end{array}$ & $\begin{array}{l}2.93^{* * *} \\
{[0.218]}\end{array}$ \\
\hline \multicolumn{5}{|c|}{ Manufacturing (Value added per employee) } \\
\hline 11-25 percentile & $\begin{array}{l}1.96^{* * *} \\
{[0.277]}\end{array}$ & $\begin{array}{c}0.70 \\
{[0.211]}\end{array}$ & $\begin{array}{l}1.76^{* * *} \\
{[0.357]}\end{array}$ & $\begin{array}{l}1.44^{* * *} \\
{[0.113]}\end{array}$ \\
\hline 26-50 percentile & $\begin{array}{l}2.45^{* * *} \\
{[0.315]}\end{array}$ & $\begin{array}{c}0.72 \\
{[0.200]}\end{array}$ & $\begin{array}{l}2.15^{* * *} \\
{[0.394]}\end{array}$ & $\begin{array}{l}1.85^{* * *} \\
{[0.126]}\end{array}$ \\
\hline 51-75 percentile & $\begin{array}{l}2.26^{* * *} \\
{[0.297]}\end{array}$ & $\begin{array}{l}0.51^{* *} \\
{[0.146]}\end{array}$ & $\begin{array}{l}1.61^{* * *} \\
{[0.310]}\end{array}$ & $\begin{array}{l}1.97^{* * *} \\
{[0.131]}\end{array}$ \\
\hline 76-90 percentile & $\begin{array}{l}2.40^{* * *} \\
{[0.342]}\end{array}$ & $\begin{array}{l}0.56^{* *} \\
{[0.172]}\end{array}$ & $\begin{array}{l}1.82^{* * *} \\
{[0.383]}\end{array}$ & $\begin{array}{l}2.04^{* * *} \\
{[0.139]}\end{array}$ \\
\hline 91-100 percentile & $\begin{array}{l}2.65^{* * *} \\
{[0.376]} \\
\end{array}$ & $\begin{array}{l}0.48^{* * *} \\
{[0.146]}\end{array}$ & $\begin{array}{l}1.77^{* * *} \\
{[0.380]}\end{array}$ & $\begin{array}{l}2.17^{* * *} \\
{[0.153]}\end{array}$ \\
\hline \multicolumn{5}{|c|}{ Manufacturing (Total factor productivity) } \\
\hline 11-25 percentile & $\begin{array}{l}1.33^{* * *} \\
{[0.136]}\end{array}$ & $\begin{array}{c}0.94 \\
{[0.212]}\end{array}$ & $\begin{array}{l}1.33^{*} \\
{[0.220]}\end{array}$ & $\begin{array}{l}1.06 \\
{[0.077]}\end{array}$ \\
\hline 26-50 percentile & $\begin{array}{l}1.66^{* * *} \\
{[0.153]}\end{array}$ & $\begin{array}{c}0.86 \\
{[0.181]}\end{array}$ & $\begin{array}{l}1.58^{* * *} \\
{[0.238]}\end{array}$ & $\begin{array}{l}1.28^{* * *} \\
{[0.097]}\end{array}$ \\
\hline $51-75$ percentile & $\begin{array}{l}2.21^{* * *} \\
{[0.198]}\end{array}$ & $\begin{array}{c}0.80 \\
{[0.163]}\end{array}$ & $\begin{array}{l}1.98^{* * *} \\
{[0.290]}\end{array}$ & ${ }_{[0.124]}^{1.61^{* * *}}$ \\
\hline 76-90 percentile & $\begin{array}{l}2.26^{* * *} \\
{[0.211]}\end{array}$ & $\begin{array}{c}0.87 \\
{[0.183]}\end{array}$ & $\begin{array}{l}2.11^{* * *} \\
{[0.322]}\end{array}$ & $\begin{array}{l}1.72^{* * *} \\
{[0.138]}\end{array}$ \\
\hline 91-100 percentile & $\begin{array}{l}2.54^{* * *} \\
{[0.242]}\end{array}$ & $\begin{array}{c}1.08 \\
{[0.231]} \\
\end{array}$ & $\begin{array}{l}2.70^{* * *} \\
{[0.417]}\end{array}$ & $\begin{array}{l}2.33^{* * *} \\
{[0.204]}\end{array}$ \\
\hline
\end{tabular}

Notes: Robust standard errors, clustered by establishment, are in brackets. $\left({ }^{*}\right),\left({ }^{* *}\right),\left(*^{* *}\right)$ indicate significance at $10 \%, 5 \%, 1 \%$, respectively. Models include all other explanatory variables 


\section{Appendix}

\section{A Proofs}

The following lemma will be used in the proof for Lemma 1.

Lemma 2 Let $G(x)$ be a bounded, (non-decreasing) increasing, (strictly) convex function in $x$, where $x$ is a normally distributed random variable with mean $\mu$ and variance $\sigma^{2} . E[G(x)]$ is (non-decreasing) increasing and (strictly) convex in $\mu$.

Proof. Observe that

$$
E[G(x)]=\int G(x) \frac{1}{\sigma \sqrt{2 \pi}} \exp \left[-\frac{(x-\mu)^{2}}{2 \sigma^{2}}\right] d x .
$$

Now,

$$
\begin{aligned}
E[G(x)] & =\int G(x-\mu+\mu) \frac{1}{\sigma \sqrt{2 \pi}} \exp \left[-\frac{(x-\mu)^{2}}{2 \sigma^{2}}\right] d x \\
& =\int G(\widetilde{x}+\mu) \frac{1}{\sigma \sqrt{2 \pi}} \exp \left[-\frac{\widetilde{x}^{2}}{2 \sigma^{2}}\right] d x
\end{aligned}
$$

where $\widetilde{x}=x-\mu$. It immediately follows that $E[G(x)]$ is (strictly) increasing and convex in $\mu$ by differentiating with respect to $\mu$.

Proof of Lemma 1. Existence and uniqueness of $D$. Let $\mathbf{T}$ be the operator defined by

$$
D^{n+1} \equiv \mathbf{T} D^{n}=B\left(x_{a}\right)+\beta\left\{E\left[\left(1-\omega_{a+1}\right) D^{n} \mid \mu_{a}, a\right]-c\right\}
$$

$\mathbf{T}$ has a unique fixed point, $D$, by the Banach fixed point theorem. To establish this result, note that $\mathbf{T}$ satisfies Blackwell's sufficiency condition for a contraction mapping - Stokey and Lucas (1989, Theorem 3.3). The operator $\mathbf{T}$ maps a bounded function $D^{n}$ into another bounded function, $D^{n+1}$, because $B, \omega_{a+1}$, and $c$ are bounded. Similarly, if $D^{n}$ is continuous in $s_{a+1}$, then so is $\mathbf{T} D^{n}$ in $s_{a}$. On this, $\mathbf{T} D^{n}$ can be trivially seen from (21) to be continuous in $x_{a}$ and $c$. Note that $D^{n}$ is a function of the random variables $x_{a+1}$ and $\mu_{a+1}$. The distribution for $x_{a+1}$ is normal with mean $\mu_{a}$ and variance $\sigma_{a}^{2}$. Recall that $\sigma_{a}^{2}$ evolves as a deterministic function of $a$. The distribution function for $\mu_{a+1}$ is also normal with mean $\mu_{a}$ and variance $\left(1-\theta_{a}\right)^{2} \sigma_{a}^{2}$, from (6). Therefore, $E\left[\left(1-\omega_{a+1}\right) D^{n} \mid \mu_{a}, a\right]$ is a continuous function of $\mu_{a}$, and hence so is $\mathbf{T} D^{n}$. To 
see that Blackwell's sufficiency condition holds, note that, first, $\mathbf{T}$ is monotone: for any two functions $D_{1}^{n} \geq D_{2}^{n}$, it follows that $\mathbf{T} D_{1}^{n} \geq \mathbf{T} D_{2}^{n}$. Second, $\mathbf{T}$ satisfies the discounting hypothesis for any constant $b>0$ :

$$
\begin{aligned}
\mathbf{T}\left(D^{n}+b\right) & =B\left(x_{a}\right)+\beta\left\{E\left[\left(1-\omega_{a+1}\right)\left(D^{n}+b\right) \mid \mu_{a}, a\right]-c\right\} \\
& =B\left(x_{a}\right)+\beta\left\{E\left[\left(1-\omega_{a+1}\right) D^{n} \mid \mu_{a}, a\right]-c\right\}+\beta\left(1-\omega_{a+1}\right) b \\
& =\mathbf{T} D^{n}+\beta\left(1-\omega_{a+1}\right) b \\
& <\mathbf{T} D^{n}+\beta b,
\end{aligned}
$$

because $1-\omega_{a+1}<1$. Hence, T satisfies Blackwell's sufficiency condition.

$D$ is increasing in $x_{a}$. Observe that $x_{a}$ only enters into $B\left(x_{a}\right)$ in $(21)$, given $\mu_{a}$. The result then immediately follows from the fact that $B\left(x_{a}\right)$ is increasing in $x_{a}$.

$D$ is decreasing in $c$. Trivially, the function $\beta\left(E\left[\left(1-\omega_{a+1}\right) D\left(s_{a+1}\right)\right]-c\right)$ is decreasing in $c$. Therefore, so is $D\left(s_{a}\right)$.

$D$ is increasing in $\mu_{a}$. Assume that $D^{n}$ is non-decreasing in $\mu_{a+1}$. It will now be shown that this implies that $\mathbf{T} D^{n}$ is increasing in $\mu_{a}$. Again, $D^{n}$ is a function of the random variables $x_{a+1}$ and $\mu_{a+1}$. The distribution function for $x_{a+1}$ is normal with mean $\mu_{a}$. Now, $B\left(x_{a+1}\right)$ is increasing in $x_{a+1}$. Hence, on this account, a higher value for $\mu_{a}$ implies a higher value for $E\left[\left(1-\omega_{a+1}\right) D^{n} \mid \mu_{a}, a\right]$, because $D^{n}$ is an increasing function of $x_{a+1}$ - Lemma 2. Likewise, $\mu_{a+1}$ is normally distributed with mean $\mu_{a}$. Therefore, on this account, $\mathbf{T} D^{n}$ is non-decreasing in $\mu_{a}$, and $D^{n}$ is non-decreasing in $\mu_{a+1}$ - again, Lemma 2. Putting both pieces together implies that $\mathbf{T} D^{n}$ is increasing in $\mu_{a}$. Consequently, $\mathbf{T}$ maps a non-decreasing function in $\mu_{a}$ into increasing ones. By Stokey and Lucas (1989, Theorem 3.2, Corollary 1) the fixed point $D$ must then be increasing in $\mu_{a}$.

Convexity of $D$ in $\mu_{a}$ and $x_{a}$. It is easy to see that $D^{n+1}$ is strictly convex in $x_{a}$ because $B\left(x_{a}\right)$ is strictly convex in $x_{a}$ and $\beta\left\{E\left[\left(1-\omega_{a+1}\right) D^{n} \mid \mu_{a}, a\right]-c\right\}$ does not depend on $x_{a}$, given $\mu_{a}$. Suppose now that $D^{n}$ is a convex function of $\mu_{a}$. Consider two priors, $\mu_{1}$ and $\mu_{2}$. Let $\mu_{\lambda}=\lambda \mu_{1}+(1-\lambda) \mu_{2}$, for $\lambda \in(0,1)$. Convexity of $\mathbf{T} D^{n}$ requires $\lambda\left(\mathbf{T} D^{n}\right)\left(\mu_{1}, a, x_{a}, \omega_{a+1}\right)+(1-$ $\lambda)\left(\mathbf{T} D^{n}\right)\left(\mu_{2}, a, x_{a}, \omega_{a+1}\right) \geq\left(\mathbf{T} D^{n}\right)\left(\mu_{\lambda}, a, x_{a}, \omega_{a+1}\right)$. Now, again $D^{n}$ is a function of the random variables $x_{a+1}$ and $\mu_{a+1}$. The distribution of $x_{a+1}$ is normal with mean $\mu_{a}$ and variance $\sigma_{a}^{2}$, 
while the distribution of $\mu_{a+1}$ is also normal with mean $\mu_{a}$ and variance $\left(1-\theta_{a}\right)^{2} \sigma_{a}^{2}$. Note that

$$
\begin{aligned}
& \lambda\left(\mathbf{T} D^{n}\right)\left(\mu_{1}, a, x_{a}, \omega_{a+1}\right)+(1-\lambda)\left(\mathbf{T} D^{n}\right)\left(\mu_{2}, a, x_{a}, \omega_{a+1}\right) \\
&=\lambda\left\{B\left(x_{a}\right)+\beta E\left[\left(1-\omega_{a+2}\right) D^{n}\left(\mu_{a+1}, a+1, x_{a+1}, \omega_{a+2}\right) \mid \mu_{1}, a\right]-\beta c\right\} \\
&+(1-\lambda)\left\{B\left(x_{a}\right)+\beta E\left[\left(1-\omega_{a+2}\right) D^{n}\left(\mu_{a+1}, a+1, x_{a+1}, \omega_{a+2}\right) \mid \mu_{2}, a\right]-\beta c\right\} \\
&>B\left(x_{a}\right)+\beta E\left[(1-\omega) D^{n}\left(\mu_{a+1}, a+1, x_{a+1}, \omega_{a+2}\right) \mid \mu_{\lambda}, a\right]-\beta c \\
&=\left(\mathbf{T} D^{n}\right)\left(\mu_{\lambda}, a, x_{a}, \omega_{a+1}\right) .
\end{aligned}
$$

The inequality follows from the facts that $D^{n}$ is convex in $\mu_{a+1}$ and strictly convex in $x_{a+1}$ and an application of Lemma 2. Thus, $\mathbf{T}$ maps convex functions into strictly convex functions. Therefore, $D$ is strictly convex in $\mu_{a}$-Stokey and Lucas (1989, Theorem 3.2, Corollary 1).

$D$ is decreasing in $a$. From above, $D\left(\mu_{a+1}, a+1, x_{a+1}, \omega_{a+2}\right)$ is a bounded, increasing, strictly convex function of the random variables $x_{a+1}$ and $\mu_{a+1}$. The random variable $x_{a+1}$ is normally distributed with mean $\mu_{a}$ and variance $\sigma_{a}^{2}$, while $\mu_{a+1}$ is normally distributed with mean $\mu_{a}$ and variance $\left(1-\theta_{a}\right)^{2} \sigma_{a}^{2}$. Now, as can be seen from (3) and (5), $\sigma_{a}^{2}$ decreases with age, $a$. Therefore, an increase in $a$, ceteris paribus, amounts to a mean-preserving shrinkage in $x_{a+1}$ and $\mu_{a+1}$. As a result, $E\left[D\left(\mu_{a+1}, a+1, x_{a+1}, \omega_{a+2}\right) \mid \mu_{a-1}, a\right]$ is decreasing in $a$ by Hadar and Russell (1971, Theorem 3).

$E\left[D \mid \mu_{a-1}, a\right]$ is increasing in $\mu_{a-1}$ and decreasing in a. Prior to observing $x_{a}$, the union will take $\mu_{a}$ and $x_{a}$ to be normally distributed random variables with mean $\mu_{a-1}$. From the parts above, $D\left(\mu_{a}, a, x_{a}, \omega_{a+1}\right)$ is increasing in both $\mu_{a}$ and $x_{a}$, decreasing in $a$ and strictly convex in $\mu_{a}$ and $x_{a}$. Consequently, $E\left[D\left(\mu_{a}, a, x_{a}, \omega_{a+1}\right) \mid \mu_{a-1}, a\right]$ is increasing in $\mu_{a-1}$ and decreasing in $a$.

Proof of Proposition 1. By definition, $T\left(\mu_{a-1}, a\right)=1-\Gamma\left(c / E\left[D\left(\mu_{a}, a, x_{a}, \omega_{a+1}\right) \mid \mu_{a-1}, a\right]\right)$. First, note that $\Gamma$ is a decreasing function of $E\left[D\left(\mu_{a}, a, x_{a}, \omega_{a+1}\right) \mid \mu_{a-1}, a\right]$, since $\Gamma$ is a c.d.f. Therefore, $1-\Gamma$ is an increasing function of $E\left[D\left(\mu_{a}, a, x_{a}, \omega_{a+1}\right) \mid \mu_{a-1}, a\right]$. By Lemma 1 , this last expectation is increasing in $\mu_{a-1}$ and decreasing in $a$. Therefore, so is $T$.

Proof of Proposition 2. By definition, $W\left(\mu_{a-1}, a\right)=E\left[\omega_{a} \mid \omega_{a}>\widetilde{\omega}\left(\mu_{a-1}, a\right)\right]$. But the definition of $\widetilde{\omega}\left(\mu_{a-1}, a\right)$ in (12) and Lemma 1 imply that $\widetilde{\omega}\left(\mu_{a-1}, a\right)$ is decreasing in $\mu_{a-1}$ and increasing in $a$. Therefore, $W\left(\mu_{a-1}, a\right)$ is also decreasing in $\mu_{a-1}$ and increasing in $a$.

Proof of Proposition 3. By the definition of $U$ in (14), $U$ is increasing in $\mu_{a-1}$ if $T$ is. But, $T$ is increasing in $\mu_{a-1}$ by Proposition 1. Therefore, so is $U$. Moreover, $U$ is increasing in $a$ 
because $U\left(\mu_{a-1}, \mu_{a-2}, \cdots, \mu_{0}, a\right)-U\left(\mu_{a-2}, \cdots, \mu_{0}, a-1\right)=\left\{\prod_{k=1}^{a}\left[1-O\left(\mu_{k-1}, k\right)\right]\right\} O\left(\mu_{a-1}, a\right)>$ 0 .

Proof of Proposition 4. The proof is in two parts. First, suppose that the c.d.f. governing the observer's beliefs $\Omega\left(\mu_{a-1} \mid x_{a}, a\right)$ is increasing in $x_{a}$ in the sense of first-order stochastic dominance. Now, $T\left(\mu_{a-1}, a\right)$ is increasing in $\mu_{a-1}$ by Proposition 1. The integral in (15) is then increasing in $x_{a}$ - Hadar and Russell (1971, Theorem 1). As a consequence, $T^{o}\left(x_{a}, a\right)$ is increasing in $x_{a}$.

Second, it will now be established that $\Omega\left(\mu_{a-1} \mid x_{a}, a\right)$ is increasing in $x_{a}$ in the sense of first-order stochastic dominance. Let $\psi\left(\mu_{a-1} \mid x_{a}, a\right)$ be the density function associated with $\Omega$. Bayes' Rule implies

$$
\psi\left(\mu_{a-1} \mid x_{a}, a\right)=\frac{\phi\left(x_{a} \mid \mu_{a-1}, a\right) \psi\left(\mu_{a-1} \mid a\right)}{\phi\left(x_{a} \mid a\right)},
$$

where $\psi\left(\mu_{a-1} \mid a\right)=\int \psi\left(\mu_{a-1} \mid x_{a}, a\right) d x_{a}, \phi\left(x_{a} \mid \mu_{a-1}, a\right)$ is the density associated with $\Phi\left(x_{a} \mid \mu_{a-1}, a\right)$, and $\phi\left(x_{a} \mid a\right)=\int \phi\left(x_{a} \mid \mu_{a-1}, a\right) d \mu_{a-1}$. First, it will be shown that $\psi\left(\mu_{a-1} \mid x_{a}, a\right)$ satisfies the monotone likelihood ratio property (MLRP). The MLRP is satisfied strictly if, given $x_{2}>x_{1}$, the following inequality holds

$$
\psi\left(\mu_{a-1} \mid x_{2}, a\right) \psi\left(\mu_{a-1}^{\prime} \mid x_{1}, a\right)-\psi\left(\mu_{a-1} \mid x_{1}, a\right) \psi\left(\mu_{a-1}^{\prime} \mid x_{2}, a\right)>0, \text { for } \mu_{a-1}>\mu_{a-1}^{\prime}
$$

[See, e.g., Karlin and Rubin (1956), equation (2)]. For differentiable density functions, (23) implies

$$
\frac{d}{d \mu_{a-1}} \frac{\psi\left(\mu_{a-1} \mid x_{2}, a\right)}{\psi\left(\mu_{a-1} \mid x_{1}, a\right)}>0
$$

assuming that $\psi\left(\mu_{a-1} \mid x_{1}, a\right) \neq 0$ (which will be satisfied for a normal density). Using the definition of $\psi$ in (22), rewrite the sufficient condition for the MLRP (24) as

$$
\frac{d}{d \mu_{a-1}}\left[\frac{\phi\left(x_{1} \mid a\right)}{\phi\left(x_{2} \mid a\right)} \frac{\phi\left(x_{2} \mid \mu_{a-1}, a\right)}{\phi\left(x_{1} \mid \mu_{a-1}, a\right)}\right]=\frac{\phi\left(x_{1} \mid a\right)}{\phi\left(x_{2} \mid a\right)} \frac{d}{d \mu_{a-1}}\left[\frac{\phi\left(x_{2} \mid \mu_{a-1}, a\right)}{\phi\left(x_{1} \mid \mu_{a-1}, a\right)}\right]>0 .
$$

Now, $\phi$ is the density of a normal random variable with mean $\mu_{a-1}$ and variance $\sigma_{a-1}^{2}$. Therefore,

$$
\begin{aligned}
\frac{d}{d \mu_{a-1}}\left[\frac{\phi\left(x_{2} \mid \mu_{a-1}, a\right)}{\phi\left(x_{1} \mid \mu_{a-1}, a\right)}\right]=\frac{1}{\sqrt{2 \pi} \sigma_{a-1}} & \frac{d}{d \mu_{a-1}} \exp \left[\frac{\left(x_{1}-\mu_{a-1}\right)^{2}-\left(x_{2}-\mu_{a-1}\right)^{2}}{2 \sigma_{a-1}^{2}}\right] \\
= & \frac{1}{\sqrt{2 \pi} \sigma_{a-1}} \frac{\left(x_{2}-x_{1}\right)}{\sigma_{a-1}^{2}} \exp \left[\frac{\left(x_{1}-\mu_{a-1}\right)^{2}-\left(x_{2}-\mu_{a-1}\right)^{2}}{2 \sigma_{a-1}^{2}}\right]>0
\end{aligned}
$$

where the inequality follows because $x_{2}>x_{1}$. Thus, $\psi\left(\mu_{a-1} \mid x_{a}, a\right)$ satisfies the MLRP strictly. This implies that $\Omega$ is increasing in $x_{a}$ in the sense of first-order stochastic dominance - Milgrom (1981). 
Proof of Proposition 5. Note that

$$
\begin{aligned}
W^{o}\left(x_{a}, a\right) & =\int W\left(\mu_{a-1}, a\right) d \Omega\left(\mu_{a-1} \mid x_{a}, a\right) \\
& =-\left[\int\left(-W\left(\mu_{a-1}, a\right)\right) d \Omega\left(\mu_{a-1} \mid x_{a}, a\right)\right]
\end{aligned}
$$

By Proposition 2, $W\left(\mu_{a-1}, a\right)$ is decreasing in $\mu_{a-1}$. Therefore, $-W\left(\mu_{a-1}, a\right)$ is increasing in $\mu_{a-1}$. Furthermore, $\Omega\left(\mu_{a-1} \mid x_{a}, a\right)$ is increasing in $x_{a}$ in the sense of first-order stochastic dominance, as shown in the proof of Proposition 4. Consequently, the integral inside the brackets (26) is increasing in $x_{a}$ (Hadar and Russell (1971, Theorem 1). It follows that $W^{o}\left(x_{a}, a\right)$ is decreasing in $x_{a}$.

Proof of Proposition 6. $U^{o}$ is increasing in $x_{a}$. Observe that $U\left(\mu_{a-1}, \mu_{a-2}, \cdots, \mu_{0}, a\right)$ is increasing in $\mu_{m-1}$, for $m=1, \cdots, a$, because from (14)

$$
\frac{d U\left(h_{a-1}, a\right)}{d \mu_{m-1}}=\prod_{j=1, j \neq m}^{a}\left[1-\omega_{j} T\left(\mu_{j-1}, j\right)\right] \omega_{m} \frac{d T\left(\mu_{m-1}, m\right)}{d \mu_{m-1}}>0 .
$$

The sign of the expression follows from Proposition 1. Next, let $\xi\left(\mu_{a-1}, \mu_{a-2}, \cdots, \mu_{0} \mid x_{a}, a\right)$ be the density function for the sequence of priors $\left(\mu_{a-1}, \mu_{a-2}, \cdots, \mu_{0}\right)$ conditional on $x_{a}$ and $a$. This density can be expressed in terms of a product of one-step conditional densities

$$
\xi\left(\mu_{a-1}, \mu_{a-2}, \cdots, \mu_{0} \mid x_{a}, a\right)=\psi\left(\mu_{a-1} \mid x_{a}, a\right) \zeta\left(\mu_{a-2} \mid \mu_{a-1}, a\right) \cdots \zeta\left(\mu_{1} \mid \mu_{2}, a\right)
$$

where $\zeta\left(\mu_{m-2} \mid \mu_{m-1}, m\right)$ is the density of $\mu_{m-2}$ conditioned on $\mu_{m-1}$ and $m$. The form of the above expression is justified from (6). Note that $\mu_{0}=\bar{\chi}$ is fixed (non-random). Therefore,

$$
\begin{aligned}
U^{o}\left(x_{a}, a\right) & =\int \cdots \int U\left(\mu_{a-1}, \mu_{a-2}, \cdots, \mu_{0}, a\right) \xi\left(\mu_{a-1}, \mu_{a-2}, \cdots, \mu_{0} \mid x_{a}, a\right) d \mu_{a-1} \cdots d \mu_{1} \\
& =\int I_{a-2}\left(\mu_{a-1}, a\right) \psi\left(\mu_{a-1} \mid x_{a}, a\right) d \mu_{a-1},
\end{aligned}
$$

where

$$
I_{m}\left(\mu_{m+1}, a\right)=\int I_{m-1}\left(\mu_{m}, a\right) \zeta\left(\mu_{m} \mid \mu_{m+1}, a\right) d \mu_{m}, \text { for } m=2, \cdots, a-2
$$

and

$$
I_{1}\left(\mu_{2}, a\right)=\int U\left(\mu_{a-1}, \mu_{a-2}, \cdots, \mu_{0}, a\right) \zeta\left(\mu_{1} \mid \mu_{2}, a\right) d \mu_{1}
$$

Suppose $I_{m-1}\left(\mu_{m}, a\right)$ is increasing in $\mu_{m}$. Then, $I_{m}\left(\mu_{m+1}, a\right)$ is increasing in $\mu_{m+1}$. This occurs because the c.d.f. for $\mu_{m}$ is increasing in $\mu_{m+1}$, in the sense of first-order stochastic dominance, 
by an argument similar to that employed in the proof of Proposition $4 .^{46}$ To start the induction hypothesis off, note that $I_{1}\left(\mu_{2}, a\right)$ will be increasing in $\mu_{2}$, because $U$ is strictly increasing in $\mu_{2}$ and the c.d.f. connected with $\zeta\left(\mu_{1} \mid \mu_{2}, a\right)$ is stochastically increasing in $\mu_{2}$ (in the sense of first-order stochastic dominance).

$U^{o}$ is increasing in a. Note that

$$
\begin{aligned}
& U^{o}\left(x_{a}, a+1\right)-U^{o}\left(x_{a}, a\right)= \\
& \quad \int \cdots \int U\left(\mu_{a}, \mu_{a-2}, \cdots, \mu_{0}, a+1\right) \varphi\left(\mu_{a}, \mu_{a-2}, \cdots, \mu_{0} \mid x_{a}, a+1\right) d \mu_{a} d \mu_{a-1} \cdots d \mu_{1} \\
& \quad-\int \cdots \int U\left(\mu_{a-1}, \mu_{a-2}, \cdots, \mu_{0}, a\right) \varphi\left(\mu_{a-1}, \mu_{a-2}, \cdots, \mu_{0} \mid x_{a}, a\right) d \mu_{a-1} \cdots d \mu_{1}\left(\text { for all } x_{a}\right) .
\end{aligned}
$$

Using the definition of $U\left(\mu_{a-1}, \mu_{a-2}, \cdots, \mu_{0}, a\right)$

$$
\begin{aligned}
& U\left(\mu_{a}, \mu_{a-2}, \cdots, \mu_{0}, a+1\right)-U\left(\mu_{a-1}, \mu_{a-2}, \cdots, \mu_{0}, a\right) \\
= & \prod_{k=1}^{a}\left[1-O\left(\mu_{k-1}, k\right)\right] O\left(\mu_{a}, a+1\right)>0 .
\end{aligned}
$$

Also,

$$
\varphi\left(\mu_{a}, \mu_{a-2}, \cdots, \mu_{0} \mid x_{a}, a+1\right)=\rho\left(\mu_{a} \mid \mu_{a-1}\right) \varphi\left(\mu_{a-1}, \mu_{a-2}, \cdots, \mu_{0} \mid x_{a}, a\right),
$$

where $\rho$ is the density of $\mu_{a}$ conditional on $\mu_{a-1}$. Therefore,

$$
\begin{aligned}
& U^{o}(x, a+1)-U^{o}(x, a)= \\
& \int \cdots \int U\left(\mu_{a}, \mu_{a-2}, \cdots, \mu_{0}, a+1\right) \rho\left(\mu_{a} \mid \mu_{a-1}\right) \varphi\left(\mu_{a-1}, \mu_{a-2}, \cdots, \mu_{0} \mid x, a\right) d \mu_{a} d \mu_{a-1} \cdots d \mu_{1} \\
& -\int \cdots \int U\left(\mu_{a-1}, \mu_{a-2}, \cdots, \mu_{0}, a\right) \varphi\left(\mu_{a-1}, \mu_{a-2}, \cdots, \mu_{0} \mid x, a\right) d \mu_{a-1} \cdots d \mu_{1} \\
= & \int \cdots \int\left[\int U\left(\mu_{a}, \mu_{a-2}, \cdots, \mu_{0}, a+1\right) \rho\left(\mu_{a} \mid \mu_{a-1}\right) d \mu_{a}-U\left(\mu_{a-1}, \mu_{a-2}, \cdots, \mu_{0}, a\right)\right] \\
& \times \varphi\left(\mu_{a-1}, \mu_{a-2}, \cdots, \mu_{0} \mid x, a\right) d \mu_{a-1} \cdots d \mu_{1} .
\end{aligned}
$$

${ }^{46}$ To see this, let $\Upsilon\left(\mu_{a-1} \mid \mu_{a}, a\right)$ represent the cdf that is associated with the density function $\zeta\left(\mu_{a-1} \mid \mu_{a}, a\right)$. Establishing MLRP for $\zeta\left(\mu_{a-1} \mid \mu_{a}, a\right)$ is equivalent to showing

$$
\operatorname{sign} \frac{d}{d \mu_{a-1}}\left[\frac{\xi\left(\mu_{a-1} \mid \mu_{a}^{\prime}, a\right)}{\xi\left(\mu_{a-1} \mid \mu_{a}, a\right)}\right]=\operatorname{sign} \frac{d}{d \mu_{a-1}}\left[\frac{\rho\left(\mu_{a}^{\prime} \mid \mu_{a-1}, a\right)}{\rho\left(\mu_{a} \mid \mu_{a-1}, a\right)}\right]>0,
$$

for any $\mu_{a}^{\prime}>\mu_{a}$, where $\rho\left(\mu_{a} \mid \mu_{a-1}, a\right)$ is the density of $\mu_{a}$ conditional on $\mu_{a-1}$ and $a$-follow steps similar to those used in the proof of Proposition 4. The derivation of equation (27) parrots that of (25). Note from (6) that $\rho\left(\mu_{a} \mid \mu_{a-1}, a\right)$ is the density of a normal random variable with mean $\mu_{a-1}$ and variance $\left(1-A_{a}\right)^{2}\left(\sigma_{\zeta_{a-1}}^{2}+\sigma_{\varepsilon}^{2}\right)$. By mimicing the argument outlined in the proof of Proposition 4, it can be shown that (27) holds. It follows that $\Upsilon\left(\mu_{a-1} \mid \mu_{a}, a\right)$ is increasing in $\mu_{a}$ (in the sense of first-order stochastic dominance). 
The last expression is positive if the term in brackets is positive, or if

$$
\int U\left(\mu_{a}, \mu_{a-2}, \cdots, \mu_{0}, a+1\right) \rho\left(\mu_{a} \mid \mu_{a-1}\right) d \mu_{a}>U\left(\mu_{a-1}, \mu_{a-2}, \cdots, \mu_{0}, a\right) .
$$

But note that

$$
\begin{aligned}
\int U\left(\mu_{a}, \mu_{a-2}, \cdots, \mu_{0}, a+1\right) \rho\left(\mu_{a} \mid \mu_{a-1}\right) d \mu_{a} & >\int U\left(\mu_{a-1}, \mu_{a-2}, \cdots, \mu_{0}, a\right) \rho\left(\mu_{a} \mid \mu_{a-1}\right) d \mu_{a} \\
& =U\left(\mu_{a-1}, \mu_{a-2}, \cdots, \mu_{0}, a\right),
\end{aligned}
$$

where the inequality follows from (28). Therefore, $U^{o}$ is increasing in $a$.

\section{B Derivation of $B\left(x_{a}\right)$ Under Alternative Models}

\section{B.1 Setup}

Consider a setting where an establishment produces output, $o$, according to the standard production function,

$$
o=e^{x_{a}} l^{\alpha} \text {, with } 0<\alpha<1,
$$

where $x_{a}$ drives total factor productivity, $e^{x_{a}}$, and $l$ is the amount of labor hired. This formulation for total productivity is entirely standard when productivity shocks are assumed to be normally distributed. Endow the union with the objective function

$$
\left(w-w_{c}\right)^{1-\gamma} l^{\gamma} \text {, with } 0<\gamma<1,
$$

where $w$ is the union wage rate and $w_{c}$ is the fixed wage rate in the competitive part of the economy. So, the union values a high wage premium, $w-w_{c}$, and high employment (which equates with union membership).

\section{B.2 Monopoly Union Model}

In a monopoly union model, the union will pick $w$, and then the establishment chooses $l .{ }^{47}$ The establishment's problem is

$$
\max _{l}\left\{e^{x_{a}} l^{\alpha}-w l\right\}
$$

\footnotetext{
${ }^{47}$ See Oswald (1982) for the monopoly union model. For a general exposition and discussion of all three models discussed, see also Manning $(1997,1994)$.
} 
which yields a demand for labor given by

$$
l=L\left(w, x_{a}\right)=\left[\frac{\alpha e^{x_{a}}}{w}\right]^{1 /(1-\alpha)}
$$

The union's problem is

$$
\max _{w}\left\{\left(w-w_{c}\right)^{1-\gamma}\left[\frac{\alpha e^{x_{a}}}{w}\right]^{\gamma /(1-\alpha)}\right\}
$$

which has the solution

$$
w=\frac{\gamma}{\gamma-(1-\gamma)(1-\alpha)} w_{c}
$$

provided that $\gamma-(1-\gamma)(1-\alpha)>0$, which is the condition for the objective function (31) to have an interior maximizer, $w>w_{c}$. Note that $w$ is not a function of $x_{a}$. Plugging the expression for $w$ back into the union's objective function yields

$$
B\left(x_{a}\right)=\left(w-w_{c}\right)^{1-\gamma}\left[\frac{\alpha}{w}\right]^{\gamma /(1-\alpha)} e^{\frac{\gamma}{1-\alpha} x_{a}}
$$

which is increasing and strictly convex in $x_{a}$.

\section{B.3 Right-to-Manage Model}

Consider now the case where the establishment is free to choose $l$, given the union wage, $w$, but where $w$ is determined via Nash Bargaining. ${ }^{48}$ Once again, $l$ will be determined by (30). The bargaining problem reads

$$
\max _{w}\left\{\left(e^{x_{a}} l^{\alpha}-w l\right)^{(1-\phi)}\left[\left(w-w_{c}\right)^{1-\gamma} l^{\gamma}\right]^{\phi}\right\}, \text { for } 0<\phi<1
$$

subject to (30). The objective function weights the establishment's profits and the union's objective function, where the weight $\phi$ reflects the union's bargaining power. Differentiate the objective function with respect to $w$, while making use of the fact that the establishment has chosen $l$ to maximize its profits, to obtain

$$
(1-\phi) l\left(w-w_{c}\right)^{1-\gamma}-1=\phi(1-\alpha) e^{x_{a}} l^{\alpha}\left[(1-\gamma)\left(w-w_{c}\right)^{-\gamma}+\gamma\left(w-w_{c}\right)^{1-\gamma} l^{-1}\left(\alpha e^{x_{a}}\right)^{1 /(1-\alpha)} w^{-1 /(1-\alpha)-1}\right]
$$

The solution is

$$
w=\frac{\phi \gamma+(1-\phi) \alpha}{\phi[\gamma-(1-\gamma)(1-\alpha)]+(1-\phi) \alpha} w_{c}
$$

\footnotetext{
${ }^{48}$ See Nickell (1982) for the right-to-manage model.
} 
provided that $\phi[\gamma-(1-\gamma)(1-\alpha)]+(1-\phi) \alpha>0$. Note, again, that $w$ does not depend on $x_{a}$. Therefore, $B\left(x_{a}\right)$ now reads

$$
B\left(x_{a}\right)=\left(w-w_{c}\right)^{1-\gamma}\left[\frac{\alpha}{w}\right]^{\gamma /(1-\alpha)} e^{\frac{\gamma}{1-\alpha} x_{a}}
$$

which is strictly convex in $x_{a}$.

\section{B.4 Efficient Bargaining Model}

Finally, consider efficient bargaining. ${ }^{49}$ Both $l$ and $w$ are chosen simultaneously via Nash Bargaining to solve the maximization problem

$$
\max _{w, l}\left\{\left(e^{x_{a}} l^{\alpha}-w l\right)^{(1-\phi)}\left[\left(w-w_{c}\right)^{1-\gamma} l^{\gamma}\right]^{\phi}\right\}, \text { for } 0<\phi<1
$$

The first-order conditions for $w$ and $l$ read

$$
\begin{gathered}
\phi(1-\gamma)\left(e^{x_{a}} l^{\alpha}-w l\right)-\left(w-w_{c}\right)(1-\phi) l=0 \\
\phi \gamma\left(e^{x_{a}} l^{\alpha}-w l\right)+(1-\phi)\left(\alpha e^{x_{a}} l^{\alpha}-w l\right)=0 .
\end{gathered}
$$

Adding the two equations together and rearranging yields the following relationship between the optimal choices for $w$ and $l$

$$
l=\left\{\frac{[\phi+(1-\phi) \alpha] e^{x_{a}}}{[2(1-\phi)-\phi] w-(1-\phi) w_{c}}\right\}^{1 /(1-\alpha)} .
$$

Furthermore, (35) implies

$$
w=\frac{\phi \gamma+(1-\phi) \alpha}{\phi \gamma+1-\phi} e^{x_{a}} l^{\alpha-1}
$$

Substituting (36) into (37) and rearranging yields

$$
w=\frac{(\phi \gamma+(1-\phi) \alpha)(1-\phi)}{[(\phi \gamma+(1-\phi) \alpha)(2(1-\phi)-\phi)-(\phi \gamma+1-\phi)(\phi+(1-\phi) \alpha)]} w_{c}
$$

provided that $(\phi \gamma+(1-\phi) \alpha)(2(1-\phi)-\phi)-(\phi \gamma+1-\phi)(\phi+(1-\phi) \alpha)>0$. Once again, $w$ does not depend on $x_{a}$. One can then write

$$
B\left(x_{a}\right)=\left(w-w_{c}\right)^{1-\gamma}\left\{\frac{(\phi+(1-\phi) \alpha)}{[2(1-\phi)-\phi] w-(1-\phi) w_{c}}\right\}^{\gamma /(1-\alpha)} e^{\frac{\gamma}{1-\alpha} x_{a}},
$$

which is a strictly convex function of $x_{a}$.

\footnotetext{
${ }^{49}$ See MacDonald and Solow (1981) for the efficient bargaining model.
} 


\section{Data}

\section{C.1 Trends in Certification and Decertification Elections}

The raw data from the NLRB was benchmarked against the published NLRB Annual Reports, and the agreement is quite high, as is shown in Figure C.1 (left axis: certification elections, right axis: decertification elections). The NLRB Annual Reports aggregate the certification elections (RC) and the employer-requested elections (RM). The total number of certification elections is about 7,000 per year for the period 1978-1980. Then, in 1981, it drops to 6,000 , and to about 3,500 in 1982 . It remains relatively flat until 1992, and drops to 3,000 per year. A further fall occurs during the 2000's. The raw data show basically the same trend as in the published annual reports, with two exceptions. One is a clear instance of a coverage gap in the year 1977: the raw data on NLRB certification elections contain only 4,500 elections rather than the nearly 9,000 in the NLRB Annual Report. The other occurs when the data series switches from the data for 1977-1999 to the one that was downloaded directly from www.data.gov for the period 1999-2007, with the greatest dip for the year 1997.

Figure C.1 also shows the total number of decertification elections (RD) in the raw data and the NLRB Annual Reports. These elections occur at a rate of around $800-900$ per year for the 1977-1986 period. This rate then shows a clear, gradual downward trend until 1997, when it levels at about 400 per year. As with the certification elections, there is a clear coverage gap in the year 1977.

Figure C.2 plots the union win rate in the NLRB Annual Reports and the raw data used for empirical analysis, again combining certification elections with employer-requested elections for comparability. The rate at which unions win both certification and decertification elections are basically flat until the year 1987. Unions consistently win about $47 \%$ of certification elections with a slight dip during 1981-1982, and lose about 75\% of decertification elections. After 1987, the rate at which unions lose decertification elections falls to $71 \%$ and trends downward to around $65 \%$. Starting in 1987, the rate at which unions win certification elections increases to about 50\%, where it remains until 1995, with a slight dip during the 1990-1991 recession. Thereafter, there is a slight drop around 1996, but then the rate at which unions win certification elections rises to nearly $60 \%$ by 2007 . The NLRB raw data appear to slightly understate the increase in the election win rate in recent years relative to the published report. 


\section{C.2 Statistics on Matching}

The match rate for certification and decertification elections over time are shown in Figure C.3. Considering both types of elections, the minimum match rate declines from about $80 \%$ in 1977 to $71 \%$ in 1986. It is then stable until about 1994, when it starts trending downward, reaching a low of $65 \%$ in 2000 . Then, in 2001 it sharply returns to about $70 \%$. This discontinuity corresponds roughly with a change in the structuring of the source data for the LBD that resulted in more complete and comprehensive source data. The trends in the match rate are similar for certification and decertification elections, and do not vary substantially by the election outcome, although match rates are lower in the case of decertification.

In Table C.12, the rates of match for certification elections are shown by NLRB sector, which differ from the SIC sector definitions in general. For those sectors with a substantial number of elections (Manufacturing, Retail Trade, Services, Trade, Transportation, and Utilities, and Wholesale Trade), the match rates range from $70 \%$ to $77 \%$. Construction and Manufacturing elections have higher match rates, Wholesale Trade elections match to the LBD somewhat less frequently, and Retail Trade, Services, and Trade, Transportation, and Utilities have lower match rates. 


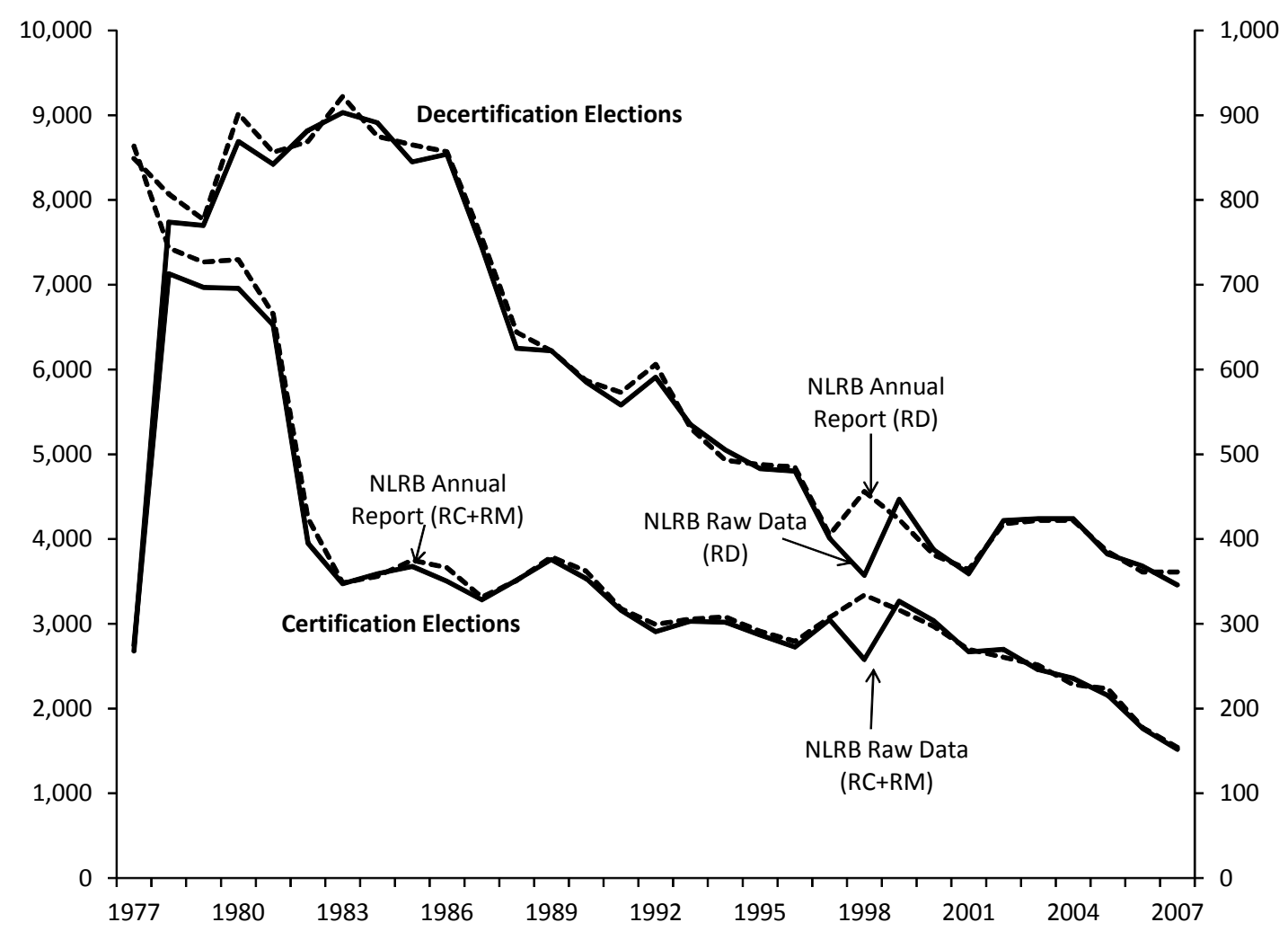

Figure C.1: The number of certification (RC+RM) and decertification (RD) elections - NLRB Annual Report versus NLRB Raw Data 


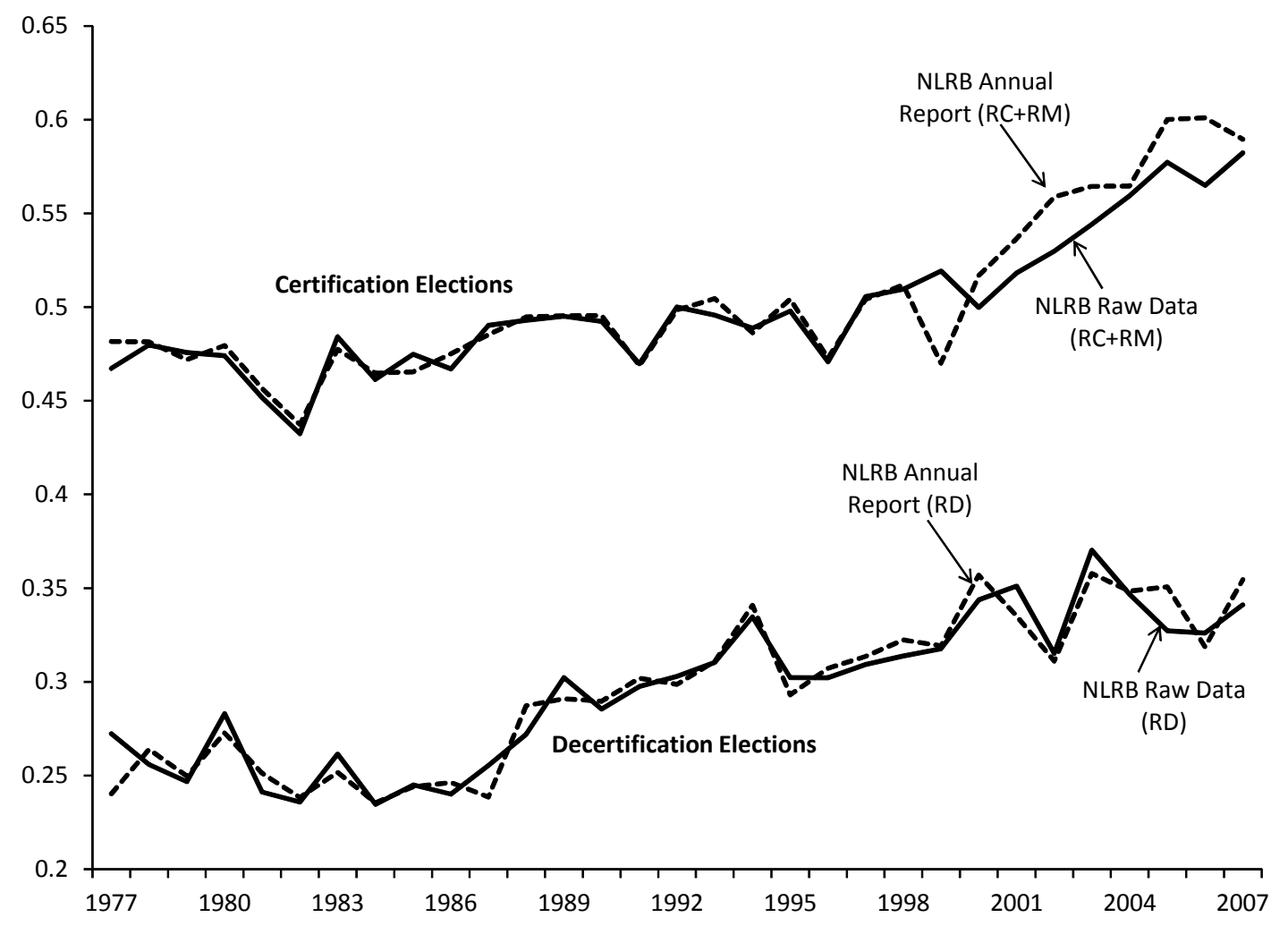

Figure C.2: Union win rate in certification $(\mathrm{RC}+\mathrm{RM})$ and decertification $(\mathrm{RD})$ elections NLRB Annual Report versus NLRB Raw Data 


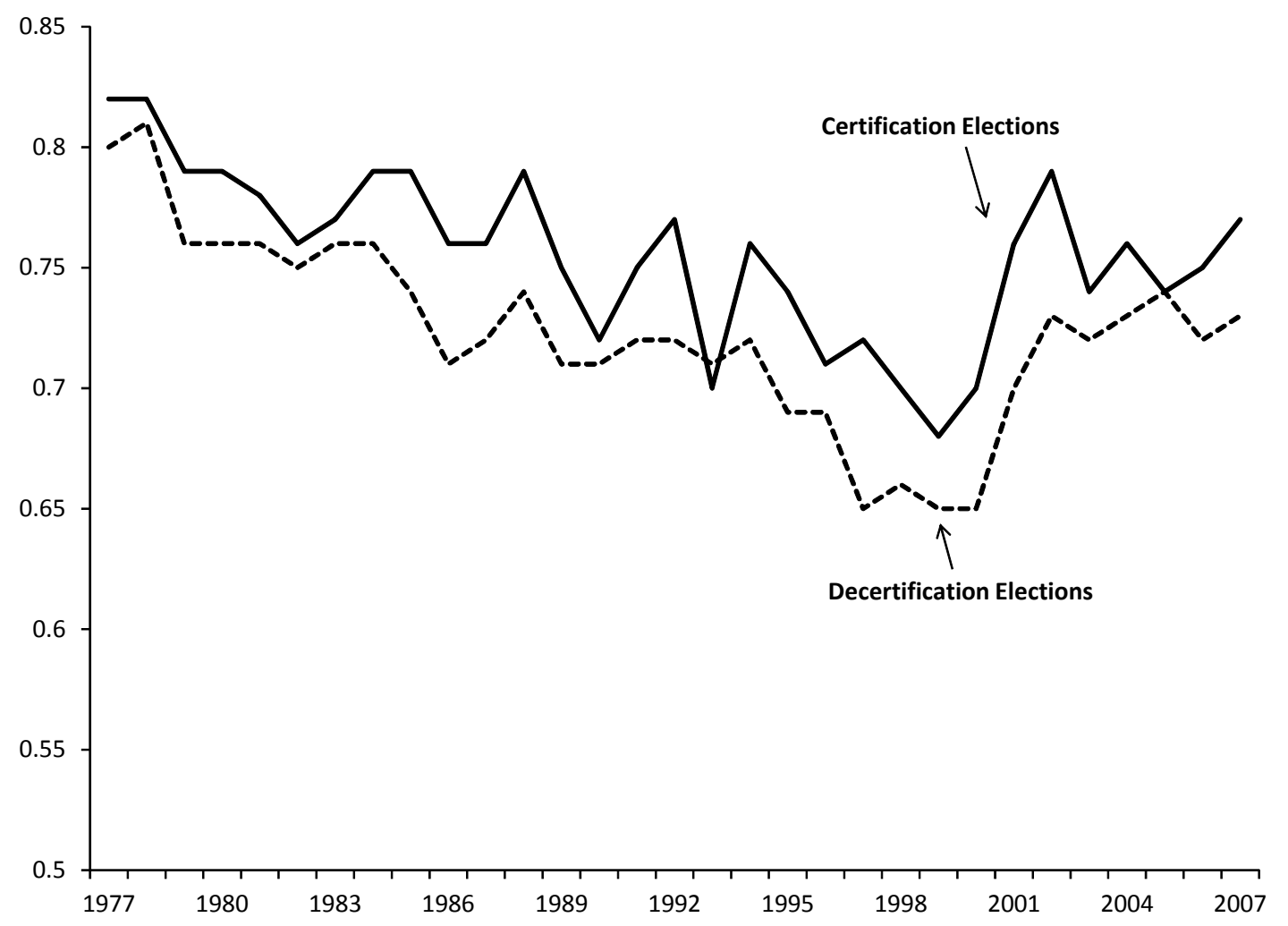

Figure C.3: Match rates by year - All sectors 
TABLE C.1. Odds ratios based on logit model estimates - All Sectors (Sample restricted to $1990-2007$ period)

\begin{tabular}{|c|c|c|c|c|}
\hline \multirow{3}{*}{$\begin{array}{l}\text { Event: } \\
\text { Probability: }\end{array}$} & \multicolumn{2}{|c|}{ Certification: } & \multirow{3}{*}{$\begin{array}{l}\text { Successful } \\
\text { Organizing } \\
O^{o}\left(x_{a}, a\right)\end{array}$} & \multirow{3}{*}{$\begin{array}{l}\text { Union } \\
\text { Status } \\
U^{o}\left(x_{a}, a\right)\end{array}$} \\
\hline & Election & Win & & \\
\hline & $T^{o}\left(x_{a}, a\right)$ & $W^{o}\left(x_{a}, a\right)$ & & \\
\hline 10-19 employees & $\begin{array}{l}2.34^{* * *} \\
{[0.041]}\end{array}$ & $\begin{array}{l}0.76^{* * *} \\
{[0.029]}\end{array}$ & $\begin{array}{l}2.98^{* * *} \\
{[0.076]}\end{array}$ & $\begin{array}{l}2.28^{* * *} \\
{[0.043]}\end{array}$ \\
\hline 20-49 employees & $\begin{array}{l}3.67^{* * *} \\
{[0.063]}\end{array}$ & $\begin{array}{l}0.62^{* * *} \\
{[0.025]}\end{array}$ & $\begin{array}{l}4.53^{* * *} \\
{[0.115]}\end{array}$ & $\begin{array}{l}3.71^{* * *} \\
{[0.078]}\end{array}$ \\
\hline 50-99 employees & $\begin{array}{l}5.46^{* * *} \\
{[0.113]}\end{array}$ & $\begin{array}{l}0.49^{* * *} \\
{[0.025]}\end{array}$ & $\begin{array}{l}6.29^{* * *} \\
{[0.194]}\end{array}$ & $\begin{array}{l}5.66^{* * *} \\
{[0.141]}\end{array}$ \\
\hline 100-249 employees & $\begin{array}{l}7.18^{* * *} \\
{[0.157]}\end{array}$ & $\begin{array}{l}0.43^{* * *} \\
{[0.024]}\end{array}$ & $\begin{array}{l}7.90^{* * *} \\
{[0.261]}\end{array}$ & $\begin{array}{l}7.60^{* * *} \\
{[0.212]}\end{array}$ \\
\hline 250-499 employees & $\begin{array}{l}8.16^{* * *} \\
{[0.276]}\end{array}$ & $\begin{array}{l}0.41^{* * *} \\
{[0.036]}\end{array}$ & $\begin{array}{l}9.16^{* * *} \\
{[0.456]}\end{array}$ & ${ }_{[0.333]}^{8.31^{* * *}}$ \\
\hline $500+$ employees & $\begin{array}{l}9.41^{* * *} \\
{[0.396]}\end{array}$ & $\begin{array}{l}0.28^{* * *} \\
{[0.031]}\end{array}$ & $\begin{array}{l}10.53^{* * *} \\
{[0.650]}\end{array}$ & $\begin{array}{l}10.91^{* * *} \\
{[0.590]}\end{array}$ \\
\hline 4-6 years & $\begin{array}{l}0.84^{* * *} \\
{[0.012]}\end{array}$ & $\begin{array}{c}0.99 \\
{[0.035]}\end{array}$ & $\begin{array}{l}0.91^{* * *} \\
{[0.020]}\end{array}$ & $\begin{array}{l}2.49^{* * *} \\
{[0.027]}\end{array}$ \\
\hline 7-9 years & $\begin{array}{l}0.79^{* * *} \\
{[0.013]}\end{array}$ & $\begin{array}{l}0.97 \\
{[0.038]}\end{array}$ & $\begin{array}{l}0.86^{* * *} \\
{[0.021]}\end{array}$ & $\begin{array}{l}3.61^{* * *} \\
{[0.049]}\end{array}$ \\
\hline 10-12 years & $\begin{array}{l}0.74^{* * *} \\
{[0.014]}\end{array}$ & $\begin{array}{l}1.04 \\
{[0.047]}\end{array}$ & $\begin{array}{l}0.84^{* * *} \\
{[0.023]}\end{array}$ & $\begin{array}{l}4.70^{* * *} \\
{[0.069]}\end{array}$ \\
\hline 13-15 years & $\begin{array}{l}0.72^{* * *} \\
{[0.015]}\end{array}$ & $\begin{array}{c}0.97 \\
{[0.048]}\end{array}$ & $\begin{array}{l}0.80^{* * *} \\
{[0.025]}\end{array}$ & $\begin{array}{l}6.07^{* * *} \\
{[0.095]}\end{array}$ \\
\hline $16-18$ years & $\begin{array}{l}0.68^{* * *} \\
{[0.018]}\end{array}$ & $\begin{array}{c}1.02 \\
{[0.062]}\end{array}$ & $\begin{array}{l}0.80^{* * *} \\
{[0.029]}\end{array}$ & $\begin{array}{l}7.45^{* * *} \\
{[0.131]}\end{array}$ \\
\hline $19-21$ years & $\begin{array}{l}0.67^{* * *} \\
{[0.021]}\end{array}$ & $\begin{array}{l}1.02 \\
{[0.074]}\end{array}$ & $\begin{array}{l}0.77^{* * *} \\
{[0.034]}\end{array}$ & $\underbrace{9.01 * *}_{[0.181]}$ \\
\hline $22-24$ years & $\begin{array}{l}0.64^{* * *} \\
{[0.027]}\end{array}$ & $\begin{array}{c}0.92 \\
{[0.090]}\end{array}$ & $\begin{array}{l}0.73^{* * *} \\
{[0.041]}\end{array}$ & $\begin{array}{l}10.59^{* * *} \\
{[0.245]}\end{array}$ \\
\hline $25+$ years & $\begin{array}{l}0.61^{* * *} \\
{[0.032]}\end{array}$ & $\begin{array}{l}1.09 \\
{[0.138]}\end{array}$ & $\begin{array}{l}0.68^{* * *} \\
{[0.047]}\end{array}$ & $\begin{array}{l}12.82^{* * *} \\
{[1.982]}\end{array}$ \\
\hline Multi-unit status & $\begin{array}{l}5.06^{* * *} \\
{[0.082]}\end{array}$ & $\begin{array}{l}0.37^{* * *} \\
{[0.014]}\end{array}$ & $\begin{array}{l}3.33^{* * *} \\
{[0.076]}\end{array}$ & $\begin{array}{l}2.94^{* * *} \\
{[0.160]}\end{array}$ \\
\hline Firm union status & $\begin{array}{l}3.59^{* * *} \\
{[0.037]}\end{array}$ & $\begin{array}{l}6.51^{* * *} \\
{[0.216]}\end{array}$ & $\begin{array}{l}6.10^{* * *} \\
{[0.081]}\end{array}$ & $\begin{array}{l}5.18^{* * *} \\
{[0.063]}\end{array}$ \\
\hline Right-to-work status & $\begin{array}{l}1.13^{*} \\
{[0.074]}\end{array}$ & $\begin{array}{l}0.78 \\
{[0.387]}\end{array}$ & $\begin{array}{c}0.93 \\
{[0.058]}\end{array}$ & ]$_{[0.057]}$ \\
\hline Eligible employees \% & - & $\begin{array}{l}0.77^{* * *} \\
{[0.006]}\end{array}$ & - & - \\
\hline
\end{tabular}

Notes: Robust standard errors, clustered by establishment, are in brackets. $(*),(* *),(* * *)$ indicate significance at $10 \%, 5 \%, 1 \%$, respectively. Models include 2-digit SIC industry, state, and year fixed effects. The following categories are omitted: 1-9 employees and 0-3 years of age. 
TABLE C.2. Odds ratios based on logit model estimates - Manufacturing (Sample restricted to 1990-2007 period)

\begin{tabular}{|c|c|c|c|c|}
\hline \multirow[t]{2}{*}{ Event: } & \multicolumn{2}{|c|}{ Certification: } & \multirow{2}{*}{$\begin{array}{l}\text { Successful } \\
\text { Organizing }\end{array}$} & \multirow{2}{*}{$\begin{array}{l}\text { Union } \\
\text { Status }\end{array}$} \\
\hline & Election & Win & & \\
\hline Probability: & $T^{o}\left(x_{a}, a\right)$ & $W^{o}\left(x_{a}, a\right)$ & $O^{o}\left(x_{a}, a\right)$ & $U^{o}\left(x_{a}, a\right)$ \\
\hline 10-19 employees & $\begin{array}{l}5.48^{* * *} \\
{[0.420]}\end{array}$ & $\begin{array}{l}0.66^{* * *} \\
{[0.107]}\end{array}$ & $\begin{array}{l}6.34^{* * *} \\
{[0.719]}\end{array}$ & $\begin{array}{l}2.42^{* * *} \\
{[0.135]}\end{array}$ \\
\hline 20-49 employees & $\begin{array}{l}13.76^{* * *} \\
{[0.964]}\end{array}$ & $\begin{array}{l}0.48^{* * *} \\
{[0.073]}\end{array}$ & $\begin{array}{l}15.16^{* * *} \\
{[1.593]}\end{array}$ & $\begin{array}{l}4.97^{* * *} \\
{[0.279]}\end{array}$ \\
\hline 50-99 employees & $\begin{array}{l}26.33^{* * *} \\
{[2.006]}\end{array}$ & $\begin{array}{l}0.31^{\text {*** }} \\
{[0.049]}\end{array}$ & $\begin{array}{l}22.31^{* * *} \\
{[2.650]}\end{array}$ & $\begin{array}{l}7.44^{* * *} \\
{[0.478]}\end{array}$ \\
\hline 100-249 employees & $\begin{array}{l}33.44^{* * *} \\
{[2.675]}\end{array}$ & $\begin{array}{l}0.23^{* * *} \\
{[0.038]}\end{array}$ & $\begin{array}{l}23.39^{* * *} \\
{[2.956]}\end{array}$ & $\begin{array}{l}8.29^{* * *} \\
{[0.589]}\end{array}$ \\
\hline 250-499 employees & $\begin{array}{l}36.45^{* * *} \\
{[3.442]}\end{array}$ & $\begin{array}{l}0.22^{* * *} \\
{[0.045]}\end{array}$ & $\begin{array}{l}26.68^{* * *} \\
{[4.117]}\end{array}$ & $\begin{array}{l}7.81^{* * *} \\
{[0.711]}\end{array}$ \\
\hline 500+ employees & $\begin{array}{l}24.56^{* * *} \\
{[2.926]}\end{array}$ & $\begin{array}{l}0.17^{* * *} \\
{[0.048]}\end{array}$ & $\begin{array}{l}17.74^{* * *} \\
{[3.504]}\end{array}$ & $\begin{array}{l}6.34^{* * *} \\
{[0.790]}\end{array}$ \\
\hline 4-6 years & $\begin{array}{l}0.84^{* * *} \\
{[0.041]}\end{array}$ & $\begin{array}{c}0.97 \\
{[0.102]}\end{array}$ & $\begin{array}{l}0.82^{* * *} \\
{[0.065]}\end{array}$ & $\begin{array}{l}2.66^{* * *} \\
{[0.105]}\end{array}$ \\
\hline $7-9$ years & $\begin{array}{l}0.79^{* * *} \\
{[0.040]}\end{array}$ & $\begin{array}{c}0.88 \\
{[0.033]}\end{array}$ & $\begin{array}{l}0.76^{* * *} \\
{[0.064]}\end{array}$ & $\begin{array}{l}4.08^{* * *} \\
{[0.197]}\end{array}$ \\
\hline 10-12 years & $\begin{array}{l}0.69^{* * *} \\
{[0.038]}\end{array}$ & $\begin{array}{c}1.04 \\
{[0.125]}\end{array}$ & $\begin{array}{l}0.73^{* * *} \\
{[0.063]}\end{array}$ & $\begin{array}{l}5.71^{* * *} \\
{[0.298]}\end{array}$ \\
\hline 13-15 years & $\begin{array}{l}0.67^{* * *} \\
{[0.040]}\end{array}$ & $\begin{array}{l}0.76^{* *} \\
{[0.104]}\end{array}$ & $\begin{array}{l}0.59^{* * *} \\
{[0.060]}\end{array}$ & $\begin{array}{l}7.72^{* * *} \\
{[0.434]}\end{array}$ \\
\hline 16-18 years & $\begin{array}{l}0.65^{* * *} \\
{[0.046]}\end{array}$ & $\begin{array}{c}0.99 \\
{[0.153]}\end{array}$ & $\begin{array}{l}0.65^{* * *} \\
{[0.074]}\end{array}$ & $\begin{array}{l}10.01^{* * *} \\
{[0.633]}\end{array}$ \\
\hline 19-21 years & $\begin{array}{l}0.62^{* * *} \\
{[0.053]}\end{array}$ & $\begin{array}{c}1.09 \\
{[0.203]}\end{array}$ & $\begin{array}{l}0.67^{* * *} \\
{[0.091]}\end{array}$ & $\begin{array}{l}12.91^{* * *} \\
{[0.921]}\end{array}$ \\
\hline $22-24$ years & $\begin{array}{l}0.54^{* * *} \\
{[0.063]}\end{array}$ & $\begin{array}{l}0.55^{* *} \\
{[0.147]}\end{array}$ & $\begin{array}{l}0.39^{* * *} \\
{[0.084]}\end{array}$ & $\begin{array}{l}16.09^{* * *} \\
{[1.295]}\end{array}$ \\
\hline $25+$ years & $\begin{array}{l}0.58^{* * *} \\
{[0.088]}\end{array}$ & $\begin{array}{l}1.26 \\
{[0.427]}\end{array}$ & $\begin{array}{l}0.62^{* * *} \\
{[0.141]}\end{array}$ & $\begin{array}{l}20.82^{* * *} \\
{[1.982]}\end{array}$ \\
\hline Multi-unit status & $\begin{array}{l}2.12^{* * *} \\
{[0.098]}\end{array}$ & $\begin{array}{l}0.72^{* * *} \\
{[0.059]}\end{array}$ & $\begin{array}{l}1.85^{* * *} \\
{[0.137]}\end{array}$ & $\begin{array}{l}2.81^{* * *} \\
{[0.160]}\end{array}$ \\
\hline Firm union status & $\begin{array}{l}2.02^{* * *} \\
{[0.086]}\end{array}$ & $\begin{array}{l}2.20^{* * *} \\
{[0.281]}\end{array}$ & $\begin{array}{l}2.99^{* * *} \\
{[0.194]}\end{array}$ & $\begin{array}{l}2.75^{* * *} \\
{[0.118]}\end{array}$ \\
\hline Right-to-work status & $\begin{array}{l}0.68^{* *} \\
{[0.120]}\end{array}$ & $\begin{array}{l}0.92 \\
{[0.373]}\end{array}$ & $\begin{array}{c}0.68 \\
{[0.192]}\end{array}$ & $\begin{array}{c}0.97 \\
{[0.088]}\end{array}$ \\
\hline Eligible employees $\%$ & - & $\begin{array}{l}0.72^{* * *} \\
{[0.027]}\end{array}$ & - & - \\
\hline
\end{tabular}

Notes: Robust standard errors, clustered by establishment, are in brackets. $\left(^{*}\right),\left({ }^{* *}\right),\left({ }^{* *}\right)$ indicate significance at $10 \%, 5 \%, 1 \%$, respectively. Models include 2-digit SIC industry, state, and year fixed effects. The following categories are omitted: 1-9 employees and 0-3 years of age. 
TABle C.3. Odds ratios based on logit model estimates - All Sectors (Sample restricted to establishments with $5+$ employees)

\begin{tabular}{|c|c|c|c|c|}
\hline \multirow{3}{*}{$\begin{array}{l}\text { Event: } \\
\text { Probability: }\end{array}$} & \multicolumn{2}{|c|}{ Certification: } & \multirow{3}{*}{$\begin{array}{l}\text { Successful } \\
\text { Organizing } \\
O^{o}\left(x_{a}, a\right)\end{array}$} & \multirow{3}{*}{$\begin{array}{l}\text { Union } \\
\text { Status } \\
U^{o}\left(x_{a}, a\right)\end{array}$} \\
\hline & Election & Win & & \\
\hline & $T^{o}\left(x_{a}, a\right)$ & $W^{o}\left(x_{a}, a\right)$ & & \\
\hline 10-19 employees & $\begin{array}{l}1.75^{* * *} \\
{[0.028]}\end{array}$ & $\begin{array}{l}0.84^{* * *} \\
{[0.029]}\end{array}$ & $1_{[0.042]}$ & $1_{[0.029]}$ \\
\hline 20-49 employees & $\begin{array}{l}3.20^{* * *} \\
{[0.052]}\end{array}$ & $\begin{array}{l}0.67^{* * *} \\
{[0.024]}\end{array}$ & $\begin{array}{l}3.18^{* * *} \\
{[0.074]}\end{array}$ & $2_{[0.062]}$ \\
\hline 50-99 employees & $\begin{array}{l}5.04^{* * *} \\
{[0.097]}\end{array}$ & $\begin{array}{l}0.56^{* * *} \\
{[0.024]}\end{array}$ & $\begin{array}{l}4.79^{* * *} \\
{[0.133]}\end{array}$ & $\begin{array}{l}4.64^{* * *} \\
{[0.119]}\end{array}$ \\
\hline 100-249 employees & $\begin{array}{l}6.83^{* * *} \\
{[0.142]}\end{array}$ & $\begin{array}{l}0.49^{* * *} \\
{[0.023]}\end{array}$ & $\begin{array}{l}6.21^{* * *} \\
{[0.190]}\end{array}$ & $\begin{array}{l}6.45^{* * *} \\
{[0.189]}\end{array}$ \\
\hline 250-499 employees & $\begin{array}{l}7.87^{* * *} \\
{[0.239]}\end{array}$ & $\begin{array}{l}0.46^{* * *} \\
{[0.032]}\end{array}$ & $\begin{array}{l}7.29^{* * *} \\
{[0.324]}\end{array}$ & $\begin{array}{l}7.33^{* * *} \\
{[0.301]}\end{array}$ \\
\hline $500+$ employees & ${ }_{[0.325]}^{8.71}$ & $\begin{array}{l}0.31^{* * *} \\
{[0.027]}\end{array}$ & $\begin{array}{l}7.98^{* * *} \\
{[0.435]}\end{array}$ & $\begin{array}{l}9.67^{* * *} \\
{[0.535]}\end{array}$ \\
\hline $4-6$ years & $\begin{array}{l}0.82^{* * *} \\
{[0.012]}\end{array}$ & $\begin{array}{l}1.06^{* *} \\
{[0.032]}\end{array}$ & $\begin{array}{l}0.87^{* * *} \\
{[0.017]}\end{array}$ & ${ }^{2.22^{* 0.022]}}$ \\
\hline 7-9 years & $\begin{array}{l}0.76^{* * *} \\
{[0.013]}\end{array}$ & $\begin{array}{l}1.00 \\
{[0.036]}\end{array}$ & $\begin{array}{l}0.79^{* * *} \\
{[0.018]}\end{array}$ & $\begin{array}{l}3.24^{* * *} \\
{[0.044]}\end{array}$ \\
\hline 10-12 years & $\begin{array}{l}0.69^{* * *} \\
{[0.014]}\end{array}$ & $\begin{array}{l}1.07 \\
{[0.046]}\end{array}$ & $\begin{array}{l}0.75^{* * *} \\
{[0.021]}\end{array}$ & $\begin{array}{l}4.12^{* * *} \\
{[0.066]}\end{array}$ \\
\hline $13-15$ years & $\begin{array}{l}0.66^{* * *} \\
{[0.016]}\end{array}$ & $\begin{array}{c}0.96 \\
{[0.049]}\end{array}$ & $\begin{array}{l}0.68^{* * *} \\
{[0.023]}\end{array}$ & $\begin{array}{l}5.16^{* * *} \\
{[0.094]}\end{array}$ \\
\hline 16-18 years & $\begin{array}{l}0.64^{* * *} \\
{[0.018]}\end{array}$ & $\begin{array}{l}1.03 \\
{[0.062]}\end{array}$ & $\begin{array}{l}0.69^{* * *} \\
{[0.027]}\end{array}$ & $\begin{array}{l}6.33^{* * *} \\
{[0.131]}\end{array}$ \\
\hline 19-21 years & $\begin{array}{l}0.63^{* * *} \\
{[0.022]}\end{array}$ & $\begin{array}{c}0.98 \\
{[0.071]}\end{array}$ & $\begin{array}{l}0.66^{* * *} \\
{[0.031]}\end{array}$ & $\begin{array}{l}7.68^{* * *} \\
{[0.182]}\end{array}$ \\
\hline $22-24$ years & $\begin{array}{l}0.59^{* * *} \\
{[0.026]}\end{array}$ & $\begin{array}{c}0.91 \\
{[0.088]}\end{array}$ & $\begin{array}{l}0.62^{* * *} \\
{[0.038]}\end{array}$ & $\underbrace{9.04 * *}_{[0.249]}$ \\
\hline $25+$ years & $\begin{array}{l}0.58^{* * *} \\
{[0.032]}\end{array}$ & $\begin{array}{l}1.08 \\
{[0.134]}\end{array}$ & $\begin{array}{l}0.63^{* * *} \\
{[0.046]}\end{array}$ & $\begin{array}{l}11.15^{* * *} \\
{[0.380]}\end{array}$ \\
\hline Multi-unit status & $1_{[0.023]}$ & $\begin{array}{c}0.51^{* * *} \\
{[0.014]}\end{array}$ & $\begin{array}{c}0.98 \\
{[0.022]}\end{array}$ & $1_{[0.033]}$ \\
\hline Firm union status & $\begin{array}{l}4.17^{* * *} \\
{[0.053]}\end{array}$ & $\begin{array}{l}4.36^{* * *} \\
{[0.124]}\end{array}$ & $\begin{array}{l}8.22^{* * *} \\
{[0.168]}\end{array}$ & $\begin{array}{l}5.98^{* * *} \\
{[0.122]}\end{array}$ \\
\hline Right-to-work status & $\begin{array}{l}1.03 \\
{[0.053]}\end{array}$ & $\begin{array}{c}0.99 \\
{[0.387]}\end{array}$ & $\begin{array}{l}1.06 \\
{[0.080]}\end{array}$ & $\begin{array}{c}0.94 \\
{[0.054]}\end{array}$ \\
\hline Eligible employees $\%$ & - & $\begin{array}{l}0.76^{* * *} \\
{[0.006]}\end{array}$ & - & - \\
\hline
\end{tabular}

Notes: Robust standard errors, clustered by establishment, are in brackets. $(*),(* *),(* * *)$ indicate significance at $10 \%, 5 \%, 1 \%$, respectively. Models include 2-digit SIC industry, state, and year fixed effects. The following categories are omitted: 5-9 employees and 0-3 years of age. 
TABle C.4. Odds ratios based on logit model estimates - Manufacturing (Sample restricted to establishments with $5+$ employees)

\begin{tabular}{|c|c|c|c|c|}
\hline \multirow{3}{*}{$\begin{array}{l}\text { Event: } \\
\text { Probability: }\end{array}$} & \multicolumn{2}{|c|}{ Certification: } & \multirow{3}{*}{$\begin{array}{l}\text { Successful } \\
\text { Organizing } \\
O^{o}\left(x_{a}, a\right)\end{array}$} & \multirow{3}{*}{$\begin{array}{l}\text { Union } \\
\text { Status } \\
U^{o}\left(x_{a}, a\right)\end{array}$} \\
\hline & Election & Win & & \\
\hline & $T^{o}\left(x_{a}, a\right)$ & $W^{o}\left(x_{a}, a\right)$ & & \\
\hline 10-19 employees & $\begin{array}{l}3.51^{* * *} \\
{[0.233]}\end{array}$ & $\begin{array}{l}0.65^{* * *} \\
{[0.107]}\end{array}$ & $\begin{array}{l}3.05^{* * *} \\
{[0.278]}\end{array}$ & $\begin{array}{l}2.22^{* * *} \\
{[0.136]}\end{array}$ \\
\hline 20-49 employees & $\begin{array}{l}9.16^{* * *} \\
{[0.576]}\end{array}$ & $\begin{array}{l}0.49^{* * *} \\
{[0.073]}\end{array}$ & ${ }^{7.277^{* * *}}$ & $\begin{array}{l}4.71^{* * *} \\
{[0.326]}\end{array}$ \\
\hline 50-99 employees & $\begin{array}{l}16.56^{* * *} \\
{[1.097]}\end{array}$ & $\begin{array}{l}0.37^{* * *} \\
{[0.049]}\end{array}$ & $\begin{array}{l}11.17^{* * *} \\
{[1.045]}\end{array}$ & $\begin{array}{l}7.55^{\text {*** }} \\
{[0.575]}\end{array}$ \\
\hline 100-249 employees & $\begin{array}{l}21.65^{* * *} \\
{[1.484]}\end{array}$ & $\begin{array}{l}0.28^{* * *} \\
{[0.038]}\end{array}$ & $\begin{array}{l}12.36^{* * *} \\
{[1.225]}\end{array}$ & $\begin{array}{l}8.82^{* * *} \\
{[0.726]}\end{array}$ \\
\hline 250-499 employees & $\begin{array}{l}23.16^{* * *} \\
{[1.837]}\end{array}$ & $\begin{array}{l}0.25^{* * *} \\
{[0.045]}\end{array}$ & $\begin{array}{l}12.87^{* * *} \\
{[1.558]}\end{array}$ & $\begin{array}{l}8.38^{* * *} \\
{[0.837]}\end{array}$ \\
\hline $500+$ employees & $\begin{array}{l}16.55^{* * *} \\
{[1.594]}\end{array}$ & $\begin{array}{l}0.17^{* * *} \\
{[0.048]}\end{array}$ & $\begin{array}{l}8.15^{* * *} \\
{[1.284]}\end{array}$ & $\begin{array}{l}6.83^{* * *} \\
{[0.891]}\end{array}$ \\
\hline $4-6$ years & $\begin{array}{l}0.83^{* * *} \\
{[0.028]}\end{array}$ & $\begin{array}{l}0.87^{*} \\
{[0.102]}\end{array}$ & $\begin{array}{l}0.76^{* * *} \\
{[0.041]}\end{array}$ & $\begin{array}{l}2.36^{* * *} \\
{[0.062]}\end{array}$ \\
\hline $7-9$ years & $\begin{array}{l}0.75^{* * *} \\
{[0.030]}\end{array}$ & $\begin{array}{c}0.87 \\
{[0.033]}\end{array}$ & $\begin{array}{l}0.71^{* * *} \\
{[0.046]}\end{array}$ & $\begin{array}{l}3.57^{* * *} \\
{[0.135]}\end{array}$ \\
\hline 10-12 years & $\begin{array}{l}0.66^{* * *} \\
{[0.032]}\end{array}$ & $\begin{array}{c}1.03 \\
{[0.125]}\end{array}$ & $\begin{array}{l}0.67^{* * *} \\
{[0.051]}\end{array}$ & $\begin{array}{l}4.89^{* * *} \\
{[0.224]}\end{array}$ \\
\hline 13-15 years & $\begin{array}{l}0.64^{* * *} \\
{[0.037]}\end{array}$ & $\begin{array}{l}0.73^{* *} \\
{[0.104]}\end{array}$ & $\begin{array}{l}0.54^{* * *} \\
{[0.053]}\end{array}$ & $\begin{array}{l}6.40^{* * *} \\
{[0.340]}\end{array}$ \\
\hline 16-18 years & $\begin{array}{l}0.62^{* * *} \\
{[0.043]}\end{array}$ & $\begin{array}{c}0.97 \\
{[0.153]}\end{array}$ & $\begin{array}{l}0.60 \text { *** } \\
{[0.067]}\end{array}$ & $\begin{array}{l}8.21^{* * *} \\
{[0.502]}\end{array}$ \\
\hline 19-21 years & $\begin{array}{l}0.59^{* * *} \\
{[0.051]}\end{array}$ & $\begin{array}{c}0.99 \\
{[0.203]}\end{array}$ & $\begin{array}{l}0.58^{* * *} \\
{[0.080]}\end{array}$ & $\begin{array}{l}10.54^{* * *} \\
{[0.742]}\end{array}$ \\
\hline $22-24$ years & $\begin{array}{l}0.51^{* * *} \\
{[0.061]}\end{array}$ & $\begin{array}{l}0.57^{* *} \\
{[0.147]}\end{array}$ & $\begin{array}{l}0.37^{* * *} \\
{[0.081]}\end{array}$ & $\begin{array}{l}12.92^{* * *} \\
{[1.060]}\end{array}$ \\
\hline $25+$ years & $\begin{array}{l}0.56^{* * *} \\
{[0.086]}\end{array}$ & $\begin{array}{l}1.30 \\
{[0.427]}\end{array}$ & $\begin{array}{l}0.61^{* *} \\
{[0.136]}\end{array}$ & $\begin{array}{l}19.96^{* * *} \\
{[1.701]}\end{array}$ \\
\hline Multi-unit status & ]$_{[0.049]}^{1.61^{* * *}}$ & $\begin{array}{l}0.77^{\text {*** }} \\
{[0.059]}\end{array}$ & $\begin{array}{l}1.40^{* * *} \\
{[0.070]}\end{array}$ & $\begin{array}{l}2.17^{* * *} \\
{[0.112]}\end{array}$ \\
\hline Firm union status & ${ }^{2.11^{0.080]}}$ & $\begin{array}{l}2.21^{* * *} \\
{[0.281]}\end{array}$ & $\begin{array}{l}3.36^{* * *} \\
{[0.189]}\end{array}$ & $\begin{array}{l}2.65^{* * *} \\
{[0.132]}\end{array}$ \\
\hline Right-to-work status & $\begin{array}{c}0.91 \\
{[0.125]}\end{array}$ & $\begin{array}{c}0.75 \\
{[0.373]}\end{array}$ & $\begin{array}{c}0.77 \\
{[0.172]}\end{array}$ & $\begin{array}{c}0.97 \\
{[0.114]}\end{array}$ \\
\hline Eligible employees \% & - & $\begin{array}{l}0.77^{* * *} \\
{[0.027]}\end{array}$ & - & - \\
\hline
\end{tabular}

Notes: Robust standard errors, clustered by establishment, are in brackets. $\left(^{*}\right),\left({ }^{* *}\right),\left({ }^{* *}\right)$ indicate significance at $10 \%, 5 \%, 1 \%$, respectively. Models include 2-digit SIC industry, state, and year fixed effects. The following categories are omitted: 5-9 employees and 0-3 years of age. 
TABLE C.5. Odds ratios based on logit model estimates (The gap between labor productivity and average wage as explanatory variable)

\begin{tabular}{|c|c|c|c|c|}
\hline \multirow{3}{*}{$\begin{array}{l}\text { Event: } \\
\text { Probability: }\end{array}$} & \multicolumn{2}{|c|}{ Certification: } & \multirow{3}{*}{$\begin{array}{l}\text { Successful } \\
\text { Organizing } \\
O^{o}\left(x_{a}, a\right)\end{array}$} & \multirow{3}{*}{$\begin{array}{l}\text { Union } \\
\text { Status } \\
U^{o}\left(x_{a}, a\right)\end{array}$} \\
\hline & Election & Win & & \\
\hline & $T^{o}\left(x_{a}, a\right)$ & $W^{o}\left(x_{a}, a\right)$ & & \\
\hline \multicolumn{5}{|c|}{ All Sectors } \\
\hline $11-25$ percentile & $\begin{array}{l}0.58^{* * *} \\
{[0.104]}\end{array}$ & $\begin{array}{c}1.13 \\
{[0.213]}\end{array}$ & $\begin{array}{c}0.49^{* * *} \\
{[0.147]}\end{array}$ & $\begin{array}{l}0.77^{*} \\
{[0.106]}\end{array}$ \\
\hline 26-50 percentile & $\begin{array}{l}0.78^{* *} \\
{[0.202]}\end{array}$ & $\begin{array}{l}0.31^{* * *} \\
{[0.093]}\end{array}$ & $\begin{array}{c}0.45^{* *} \\
{[0.160]}\end{array}$ & $\begin{array}{l}0.68^{* * *} \\
{[0.083]}\end{array}$ \\
\hline 51-75 percentile & $\begin{array}{l}1.15^{* *} \\
{[0.261]}\end{array}$ & $\begin{array}{c}0.84 \\
{[0.246]}\end{array}$ & $\begin{array}{c}0.99 \\
{[0.349]}\end{array}$ & $\begin{array}{l}1.24^{* * *} \\
{[0.126]}\end{array}$ \\
\hline 76-90 percentile & $\frac{1.29^{*}}{[0.366]}$ & $\begin{array}{c}0.71 \\
{[0.262]}\end{array}$ & $\begin{array}{c}0.82 \\
{[0.290]}\end{array}$ & $\begin{array}{l}1.38^{* * *} \\
{[0.171]}\end{array}$ \\
\hline 91-100 percentile & $\begin{array}{c}0.86 \\
{[0.263]}\end{array}$ & $\begin{array}{l}1.05 \\
{[0.345]}\end{array}$ & $\begin{array}{c}0.83 \\
{[0.424]}\end{array}$ & $\begin{array}{c}0.99 \\
{[0.223]} \\
\end{array}$ \\
\hline \multicolumn{5}{|c|}{ Manufacturing } \\
\hline 11-25 percentile & $\begin{array}{l}1.25 \\
{[0.186]}\end{array}$ & $\begin{array}{c}0.77 \\
{[0.221]}\end{array}$ & $\begin{array}{l}1.21 \\
{[0.251]}\end{array}$ & $\begin{array}{l}1.31^{* * *} \\
{[0.109]}\end{array}$ \\
\hline 26-50 percentile & $\begin{array}{l}1.86^{* * *} \\
{[0.239]}\end{array}$ & $\begin{array}{l}0.59^{*} \\
{[0.199]}\end{array}$ & ${ }_{[0.281]}^{1.54^{* * *}}$ & $\begin{array}{l}1.66^{* * *} \\
{[0.123]}\end{array}$ \\
\hline 51-75 percentile & $\begin{array}{l}1.94^{* * *} \\
{[0.249]}\end{array}$ & $\begin{array}{l}0.51^{* *} \\
{[0.176]}\end{array}$ & $\begin{array}{l}1.48^{* *} \\
{[0.271]}\end{array}$ & $\begin{array}{l}1.95^{* * *} \\
{[0.142]}\end{array}$ \\
\hline 76-90 percentile & $\begin{array}{l}2.33^{* * *} \\
{[0.308]}\end{array}$ & $\begin{array}{l}0.37^{* * *} \\
{[0.118]}\end{array}$ & ${ }_{[0.278]}^{1.41^{*}}$ & $\begin{array}{l}2.37^{* * *} \\
{[0.176]}\end{array}$ \\
\hline 91-100 percentile & $\begin{array}{l}2.63^{* * *} \\
{[0.350]}\end{array}$ & $\begin{array}{l}0.43^{* * *} \\
{[0.135]}\end{array}$ & $\begin{array}{l}1.79^{* * *} \\
{[0.349]}\end{array}$ & $\begin{array}{l}2.88^{* * *} \\
{[0.225]}\end{array}$ \\
\hline
\end{tabular}

Notes: Robust standard errors, clustered by establishment, are in brackets. $\left({ }^{*}\right),\left({ }^{* *}\right),\left(*^{* *}\right)$ indicate significance at $10 \%, 5 \%, 1 \%$, respectively. Models include all other explanatory variables in Tables 1 and 2. The 1-10 percentile category is omitted. 
TABle C.6. Odds ratios based on logit model estimates - All Sectors (The logarithm of average wage as explanatory variable)

\begin{tabular}{|c|c|c|c|c|}
\hline \multirow{3}{*}{$\begin{array}{l}\text { Event: } \\
\text { Probability: }\end{array}$} & \multicolumn{2}{|c|}{ Certification: } & \multirow{3}{*}{$\begin{array}{l}\text { Successful } \\
\text { Organizing } \\
O^{o}\left(x_{a}, a\right)\end{array}$} & \multirow{3}{*}{$\begin{array}{l}\text { Union } \\
\text { Status } \\
U^{o}\left(x_{a}, a\right)\end{array}$} \\
\hline & Election & Win & & \\
\hline & $T^{o}\left(x_{a}, a\right)$ & $W^{o}\left(x_{a}, a\right)$ & & \\
\hline log(average wage) & $\begin{array}{l}1.22^{* * *} \\
{[0.006]}\end{array}$ & $\begin{array}{c}0.99 \\
{[0.029]}\end{array}$ & ${ }^{1.19} 9^{* * *}$ & $\begin{array}{l}1.16^{* * *} \\
{[0.009]}\end{array}$ \\
\hline 10-19 employees & $\begin{array}{l}2.21^{* * *} \\
{[0.034]}\end{array}$ & $\begin{array}{l}0.73^{* * *} \\
{[0.023]}\end{array}$ & $\begin{array}{l}2.53^{* * *} \\
{[0.055]}\end{array}$ & $\begin{array}{l}2.12^{* * *} \\
{[0.040]}\end{array}$ \\
\hline 20-49 employees & $\begin{array}{l}3.61^{\text {*** }} \\
{[0.057]}\end{array}$ & $\begin{array}{l}0.59^{\text {*** }} \\
{[0.019]}\end{array}$ & $\begin{array}{l}3.94^{* * *} \\
{[0.091]}\end{array}$ & $\begin{array}{l}3.44^{* * *} \\
{[0.078]}\end{array}$ \\
\hline 50-99 employees & $\begin{array}{l}5.03^{* * *} \\
{[0.094]}\end{array}$ & $\begin{array}{l}0.48^{* * *} \\
{[0.019]}\end{array}$ & $\begin{array}{l}5.14^{* * *} \\
{[0.143]}\end{array}$ & $\begin{array}{l}4.95^{* * *} \\
{[0.133]}\end{array}$ \\
\hline 100-249 employees & $\begin{array}{l}6.11^{* * *} \\
{[0.124]}\end{array}$ & $\begin{array}{l}0.39^{* * *} \\
{[0.018]}\end{array}$ & $\begin{array}{l}5.86^{* * *} \\
{[0.179]}\end{array}$ & $\begin{array}{l}6.09^{* * *} \\
{[0.187]}\end{array}$ \\
\hline 250-499 employees & $\begin{array}{l}6.50^{* * *} \\
{[0.195]}\end{array}$ & $\begin{array}{l}0.37^{* * *} \\
{[0.026]}\end{array}$ & $\begin{array}{l}6.29^{* * *} \\
{[0.279]}\end{array}$ & $\begin{array}{l}6.46^{* * *} \\
{[0.274]}\end{array}$ \\
\hline $500+$ employees & $\begin{array}{l}6.81^{* * *} \\
{[0.254]}\end{array}$ & $\begin{array}{l}0.22^{* * *} \\
{[0.020]}\end{array}$ & $\begin{array}{l}6.35^{* * *} \\
{[0.349]}\end{array}$ & $\begin{array}{l}7.83^{* * *} \\
{[0.446]}\end{array}$ \\
\hline $4-6$ years & $\begin{array}{l}0.84^{* * *} \\
{[0.011]}\end{array}$ & $\begin{array}{c}1.04 \\
{[0.029]}\end{array}$ & $\begin{array}{l}0.92^{* * *} \\
{[0.017]}\end{array}$ & $\begin{array}{l}2.45^{* * *} \\
{[0.023]}\end{array}$ \\
\hline $7-9$ years & $\begin{array}{l}0.77^{\text {*** }} \\
{[0.012]}\end{array}$ & $\begin{array}{c}0.99 \\
{[0.033]}\end{array}$ & $\begin{array}{l}0.85^{* * *} \\
{[0.019]}\end{array}$ & $\begin{array}{l}3.64^{* * *} \\
{[0.047]}\end{array}$ \\
\hline 10-12 years & $\begin{array}{l}0.71^{* * *} \\
{[0.013]}\end{array}$ & $\begin{array}{l}1.10^{* *} \\
{[0.045]}\end{array}$ & $\begin{array}{l}0.82^{* * *} \\
{[0.022]}\end{array}$ & $\begin{array}{l}4.67^{* * *} \\
{[0.070]}\end{array}$ \\
\hline $13-15$ years & $\begin{array}{l}0.68^{* * *} \\
{[0.015]}\end{array}$ & $\begin{array}{c}0.98 \\
{[0.047]}\end{array}$ & $\begin{array}{l}0.77^{* * *} \\
{[0.024]}\end{array}$ & $\begin{array}{l}5.86^{* * *} \\
{[0.100]}\end{array}$ \\
\hline 16-18 years & $\begin{array}{l}0.64^{* * *} \\
{[0.017]}\end{array}$ & $\begin{array}{c}1.03 \\
{[0.061]}\end{array}$ & $\begin{array}{l}0.75^{* * *} \\
{[0.028]}\end{array}$ & $\begin{array}{l}7.13^{* * *} \\
{[0.139]}\end{array}$ \\
\hline 19-21 years & $\begin{array}{l}0.62^{* * *} \\
{[0.020]}\end{array}$ & $\begin{array}{c}1.00 \\
{[0.071]}\end{array}$ & $\begin{array}{l}0.72^{* * *} \\
{[0.033]}\end{array}$ & $\begin{array}{l}8.55^{* * *} \\
{[0.190]}\end{array}$ \\
\hline $22-24$ years & $\begin{array}{l}0.58^{* * *} \\
{[0.024]}\end{array}$ & $\begin{array}{c}0.93 \\
{[0.088]}\end{array}$ & $\begin{array}{l}0.68^{* * *} \\
{[0.039]}\end{array}$ & $\begin{array}{l}10.02^{* * *} \\
{[0.260]}\end{array}$ \\
\hline $25+$ years & $\begin{array}{l}0.58^{* * *} \\
{[0.031]}\end{array}$ & $\begin{array}{c}1.11 \\
{[0.138]}\end{array}$ & ${ }^{0.67^{*}}{ }^{* *}$ & $\begin{array}{l}12.49^{* * *} \\
{[0.403]}\end{array}$ \\
\hline Multi-unit status & $\begin{array}{l}3.66^{* * *} \\
{[0.058]}\end{array}$ & $\begin{array}{l}0.44^{\text {*** }} \\
{[0.013]}\end{array}$ & ${ }_{[0.047]}^{1.94}$ & $\begin{array}{l}2.33^{* * *} \\
{[0.061]}\end{array}$ \\
\hline Firm union status & $\begin{array}{l}5.11^{* * *} \\
{[0.061]}\end{array}$ & $\begin{array}{l}6.01^{* * *} \\
{[0.161]}\end{array}$ & $\begin{array}{l}11.87^{* * *} \\
{[0.238]}\end{array}$ & $\begin{array}{l}7.99^{* * *} \\
{[0.164]}\end{array}$ \\
\hline Right-to-work status & $\begin{array}{c}1.02 \\
{[0.046]}\end{array}$ & $\begin{array}{c}1.15 \\
{[0.115]}\end{array}$ & $\begin{array}{c}1.26^{* * *} \\
{[0.084]}\end{array}$ & $\begin{array}{c}1.01 \\
{[0.054]}\end{array}$ \\
\hline Eligible employees $\%$ & - & $\begin{array}{l}0.75^{* * *} \\
{[0.005]}\end{array}$ & - & - \\
\hline
\end{tabular}

Notes: Robust standard errors, clustered by establishment, are in brackets. $(*),(* *),(* * *)$ indicate significance at $10 \%, 5 \%, 1 \%$, respectively. Models include 2-digit SIC industry, state, and year fixed effects.

The following categories are omitted: 1-9 employees and 0-3 years of age. 
TABLE C.7. Odds ratios based on logit model estimates - Manufacturing (The logarithm of average wage as explanatory variable)

\begin{tabular}{|c|c|c|c|c|}
\hline \multirow{3}{*}{$\begin{array}{l}\text { Event: } \\
\text { Probability: }\end{array}$} & \multicolumn{2}{|c|}{ Certification: } & \multirow{3}{*}{$\begin{array}{l}\text { Successful } \\
\text { Organizing } \\
O^{o}\left(x_{a}, a\right)\end{array}$} & \multirow{3}{*}{$\begin{array}{l}\text { Union } \\
\text { Status } \\
U^{o}\left(x_{a}, a\right)\end{array}$} \\
\hline & Election & Win & & \\
\hline & $T^{o}\left(x_{a}, a\right)$ & $W^{o}\left(x_{a}, a\right)$ & & \\
\hline $\log$ (average wage) & $\begin{array}{l}1.23^{* * *} \\
{[0.054]}\end{array}$ & $\begin{array}{l}0.73^{* * *} \\
{[0.036]}\end{array}$ & ${ }_{[0.032]}$ & $\begin{array}{l}1.01 \\
{[0.025]}\end{array}$ \\
\hline 10-19 employees & $\begin{array}{l}6.29^{* * *} \\
{[0.348]}\end{array}$ & $\begin{array}{l}0.58^{* * *} \\
{[0.070]}\end{array}$ & $\begin{array}{l}6.12^{* * *} \\
{[0.481]}\end{array}$ & $\begin{array}{l}3.32^{* * *} \\
{[0.043]}\end{array}$ \\
\hline 20-49 employees & $\begin{array}{l}15.93^{* * *} \\
{[0.825]}\end{array}$ & $\begin{array}{l}0.44^{* * *} \\
{[0.049]}\end{array}$ & $\begin{array}{l}14.21^{* * *} \\
{[1.061]}\end{array}$ & $\begin{array}{l}6.87^{\text {*** }} \\
{[0.078]}\end{array}$ \\
\hline 50-99 employees & $\begin{array}{l}28.18^{* * *} \\
{[1.592]}\end{array}$ & $\begin{array}{l}0.33^{* * *} \\
{[0.039]}\end{array}$ & $\begin{array}{l}21.39^{* * *} \\
{[1.804]}\end{array}$ & $\begin{array}{l}10.76^{* * *} \\
{[0.141]}\end{array}$ \\
\hline 100-249 employees & $\begin{array}{l}36.11^{* * *} \\
{[2.154]}\end{array}$ & $\begin{array}{l}0.25^{* * *} \\
{[0.030]}\end{array}$ & $\begin{array}{l}23.31^{* * *} \\
{[2.126]}\end{array}$ & $\begin{array}{l}12.37^{* * *} \\
{[0.212]}\end{array}$ \\
\hline 250-499 employees & $\begin{array}{l}37.89^{* * *} \\
{[2.731]}\end{array}$ & $\begin{array}{l}0.22^{* * *} \\
{[0.034]}\end{array}$ & $\begin{array}{l}23.73^{* * *} \\
{[2.736]}\end{array}$ & $\begin{array}{l}11.60^{* * * *} \\
{[0.333]}\end{array}$ \\
\hline $500+$ employees & $\begin{array}{l}26.19^{* * *} \\
{[2.385]}\end{array}$ & $\begin{array}{l}0.15^{* * *} \\
{[0.033]}\end{array}$ & $\begin{array}{l}14.65^{* * *} \\
{[2.254]}\end{array}$ & $\begin{array}{l}9.34^{* * *} \\
{[0.590]}\end{array}$ \\
\hline $4-6$ years & $\begin{array}{l}0.84^{* * *} \\
{[0.028]}\end{array}$ & $\begin{array}{c}0.85 \\
{[0.061]}\end{array}$ & $\begin{array}{l}0.78^{* * *} \\
{[0.041]}\end{array}$ & $\begin{array}{l}2.53^{* * *} \\
{[0.027]}\end{array}$ \\
\hline 7-9 years & $\begin{array}{l}0.76^{* * *} \\
{[0.030]}\end{array}$ & $\begin{array}{c}0.88 \\
{[0.075]}\end{array}$ & $\begin{array}{l}0.72^{* * *} \\
{[0.046]}\end{array}$ & $\begin{array}{l}3.87^{* * *} \\
{[0.049]}\end{array}$ \\
\hline $10-12$ years & $\begin{array}{l}0.67^{* * *} \\
{[0.032]}\end{array}$ & $\begin{array}{c}1.04 \\
{[0.106]}\end{array}$ & $\begin{array}{l}0.70^{* * *} \\
{[0.053]}\end{array}$ & $\begin{array}{l}5.366^{* * *} \\
{[0.069]}\end{array}$ \\
\hline $13-15$ years & $\begin{array}{l}0.64^{* * *} \\
{[0.037]}\end{array}$ & $\begin{array}{c}0.74 \\
{[0.096]}\end{array}$ & $\begin{array}{l}0.55^{* * *} \\
{[0.053]}\end{array}$ & $\begin{array}{l}7.07^{* * *} \\
{[0.095]}\end{array}$ \\
\hline $16-18$ years & $\begin{array}{l}0.62^{* * *} \\
{[0.045]}\end{array}$ & $\begin{array}{c}0.98 \\
{[0.144]}\end{array}$ & $\begin{array}{l}0.60^{* * *} \\
{[0.068]}\end{array}$ & ${ }_{[0.131]}^{9.11^{* * *}}$ \\
\hline 19-21 years & $\begin{array}{l}0.59^{* * *} \\
{[0.050]}\end{array}$ & $\begin{array}{c}1.05 \\
{[0.189]}\end{array}$ & $\begin{array}{l}0.61^{* * *} \\
{[0.082]}\end{array}$ & $\begin{array}{l}11.72^{* * *} \\
{[0.181]}\end{array}$ \\
\hline $22-24$ years & $\begin{array}{l}0.52^{* * *} \\
{[0.060]}\end{array}$ & $\begin{array}{c}0.56 \\
{[0.146]}\end{array}$ & $\begin{array}{l}0.37^{* * *} \\
{[0.080]}\end{array}$ & $\begin{array}{l}14.47^{* * *} \\
{[0.245]}\end{array}$ \\
\hline $25+$ years & $\begin{array}{l}0.53^{* * *} \\
{[0.082]}\end{array}$ & $\begin{array}{l}1.31 \\
{[0.431]}\end{array}$ & $\begin{array}{l}0.57^{* *} \\
{[0.129]}\end{array}$ & $\begin{array}{l}18.69^{* * *} \\
{[1.982]}\end{array}$ \\
\hline Multi-unit status & $\begin{array}{l}1.68^{* * *} \\
{[0.054]}\end{array}$ & $\begin{array}{l}0.78^{* * *} \\
{[0.045]}\end{array}$ & $\begin{array}{l}1.49^{* * *} \\
{[0.078]}\end{array}$ & $\begin{array}{l}2.36^{* * *} \\
{[0.127]}\end{array}$ \\
\hline Firm union status & $\begin{array}{l}2.13^{* * *} \\
{[0.079]}\end{array}$ & $\begin{array}{l}2.39^{* * *} \\
{[0.185]}\end{array}$ & $\begin{array}{l}3.48^{* * *} \\
{[0.191]}\end{array}$ & $\begin{array}{l}2.77^{* * *} \\
{[0.136]}\end{array}$ \\
\hline Right-to-work status & $\begin{array}{c}0.88 \\
{[0.119]}\end{array}$ & $\begin{array}{c}0.87 \\
{[0.252]}\end{array}$ & $\begin{array}{c}0.82 \\
{[0.179]}\end{array}$ & $\begin{array}{c}0.97 \\
{[0.111]}\end{array}$ \\
\hline Eligible employees \% & - & $\begin{array}{l}0.77^{* * *} \\
{[0.019]}\end{array}$ & - & - \\
\hline
\end{tabular}

Notes: Robust standard errors, clustered by establishment, are in brackets. $(*),(* *),(* * *)$ indicate significance at $10 \%, 5 \%, 1 \%$, respectively. Models include 2-digit SIC industry, state, and year fixed effects.

The following categories are omitted: 1-9 employees and 0-3 years of age. 
TABLE C.8. Odds ratios based on logit model estimates - All Sectors

(The gap between actual versus predicted log. of average wage as explanatory variable)

\begin{tabular}{|c|c|c|c|c|}
\hline \multirow{3}{*}{$\begin{array}{l}\text { Event: } \\
\text { Probability: }\end{array}$} & \multicolumn{2}{|c|}{ Certification: } & \multirow{3}{*}{$\begin{array}{l}\text { Successful } \\
\text { Organizing } \\
O^{o}\left(x_{a}, a\right)\end{array}$} & \multirow{3}{*}{$\begin{array}{l}\text { Union } \\
\text { Status } \\
U^{o}\left(x_{a}, a\right)\end{array}$} \\
\hline & Election & Win & & \\
\hline & $T^{o}\left(x_{a}, a\right)$ & $W^{o}\left(x_{a}, a\right)$ & & \\
\hline Actual - predicted log(average wage) & $\begin{array}{l}1.30^{* * *} \\
{[0.007]}\end{array}$ & $\begin{array}{l}0.98 \\
{[0.014]}\end{array}$ & $\begin{array}{l}1.25^{* * *} \\
{[0.011]}\end{array}$ & $\begin{array}{l}1.21^{* * *} \\
{[0.010]}\end{array}$ \\
\hline 10-19 employees & $\begin{array}{l}2.19^{* * *} \\
{[0.033]}\end{array}$ & $\begin{array}{l}0.74^{* * *} \\
{[0.023]}\end{array}$ & $\begin{array}{l}2.50^{* * *} \\
{[0.054]}\end{array}$ & $\begin{array}{l}2.11^{* * *} \\
{[0.039]}\end{array}$ \\
\hline 20-49 employees & $\begin{array}{l}3.59^{* * *} \\
{[0.056]}\end{array}$ & $\begin{array}{l}0.59^{* * *} \\
{[0.020]}\end{array}$ & $\begin{array}{l}3.90^{* * *} \\
{[0.088]}\end{array}$ & $\begin{array}{l}3.41^{* * *} \\
{[0.077]}\end{array}$ \\
\hline 50-99 employees & $\begin{array}{l}5.04^{* * *} \\
{[0.093]}\end{array}$ & $\begin{array}{l}0.48^{* * *} \\
{[0.019]}\end{array}$ & $\begin{array}{l}5.12^{* * *} \\
{[0.141]}\end{array}$ & $\begin{array}{l}4.95^{* * *} \\
{[0.133]}\end{array}$ \\
\hline 100-249 employees & $\begin{array}{l}6.16^{* * *} \\
{[0.123]}\end{array}$ & $\begin{array}{l}0.40^{* * *} \\
{[0.018]}\end{array}$ & $\begin{array}{l}5.88^{* * *} \\
{[0.178]}\end{array}$ & $\begin{array}{l}6.13^{* * *} \\
{[0.187]}\end{array}$ \\
\hline 250-499 employees & $\begin{array}{l}6.58^{* * *} \\
{[0.196]}\end{array}$ & $\begin{array}{l}0.37^{* * *} \\
{[0.026]}\end{array}$ & $\begin{array}{l}6.33^{* * *} \\
{[0.280]}\end{array}$ & $\begin{array}{l}6.50^{* * *} \\
{[0.275]}\end{array}$ \\
\hline $500+$ employees & $\begin{array}{l}7.05^{* * *} \\
{[0.262]}\end{array}$ & $\begin{array}{l}0.22^{* * *} \\
{[0.020]}\end{array}$ & $\begin{array}{l}6.52^{* * *} \\
{[0.357]}\end{array}$ & $\begin{array}{l}8.02^{* * *} \\
{[0.457]}\end{array}$ \\
\hline 4-6 years & $\begin{array}{l}0.85^{* * *} \\
{[0.011]}\end{array}$ & $\begin{array}{l}1.03 \\
{[0.029]}\end{array}$ & $\begin{array}{l}0.93^{* * *} \\
{[0.017]}\end{array}$ & $\begin{array}{l}2.45^{* * *} \\
{[0.023]}\end{array}$ \\
\hline 7-9 years & $\begin{array}{l}0.78^{* * *} \\
{[0.012]}\end{array}$ & $\begin{array}{c}0.99 \\
{[0.034]}\end{array}$ & $\begin{array}{l}0.87^{* * *} \\
{[0.019]}\end{array}$ & $\begin{array}{l}3.67^{* * *} \\
{[0.046]}\end{array}$ \\
\hline 10-12 years & $\begin{array}{l}0.73^{* * *} \\
{[0.013]}\end{array}$ & {$\left[\begin{array}{l}1.09^{* *} \\
{[0.045]}\end{array}\right.$} & $\begin{array}{l}0.85^{* * *} \\
{[0.022]}\end{array}$ & $\begin{array}{l}4.74^{* * *} \\
{[0.070]}\end{array}$ \\
\hline $13-15$ years & $\begin{array}{l}0.71^{* * *} \\
{[0.015]}\end{array}$ & $\begin{array}{c}0.98 \\
{[0.047]}\end{array}$ & $\begin{array}{l}0.80^{* * *} \\
{[0.025]}\end{array}$ & $\begin{array}{l}5.98^{* * *} \\
{[0.100]}\end{array}$ \\
\hline 16-18 years & $\begin{array}{l}0.67^{* * *} \\
{[0.018]}\end{array}$ & $\begin{array}{l}1.03 \\
{[0.061]}\end{array}$ & $\begin{array}{l}0.79^{* * *} \\
{[0.029]}\end{array}$ & $\begin{array}{l}7.31^{* * *} \\
{[0.139]}\end{array}$ \\
\hline 19-21 years & $\begin{array}{l}0.66^{* * *} \\
{[0.021]}\end{array}$ & $\begin{array}{l}1.00 \\
{[0.071]}\end{array}$ & $\begin{array}{l}0.76^{* * *} \\
{[0.034]}\end{array}$ & $\begin{array}{l}8.81^{* * *} \\
{[0.193]}\end{array}$ \\
\hline $22-24$ years & $\begin{array}{l}0.62^{* * *} \\
{[0.026]}\end{array}$ & $\begin{array}{c}0.93 \\
{[0.088]}\end{array}$ & $\begin{array}{l}0.72^{* * *} \\
{[0.042]}\end{array}$ & $\begin{array}{l}10.39^{* * *} \\
{[0.266]}\end{array}$ \\
\hline $25+$ years & $\begin{array}{l}0.63^{* * *} \\
{[0.033]}\end{array}$ & $\begin{array}{l}1.11 \\
{[0.136]}\end{array}$ & $\begin{array}{l}0.73^{* *} \\
{[0.051]}\end{array}$ & $\begin{array}{l}13.06^{* * *} \\
{[0.416]}\end{array}$ \\
\hline Multi-unit status & $\begin{array}{l}3.89^{* * *} \\
{[0.059]}\end{array}$ & $\begin{array}{l}0.44^{* * *} \\
{[0.013]}\end{array}$ & $\begin{array}{l}2.03^{* * *} \\
{[0.049]}\end{array}$ & $\begin{array}{l}2.45^{* * *} \\
{[0.063]}\end{array}$ \\
\hline Firm union status & $\begin{array}{l}5.13^{* * *} \\
{[0.060]}\end{array}$ & $\begin{array}{l}6.00^{* * *} \\
{[0.161]}\end{array}$ & $\begin{array}{l}11.92^{* * *} \\
{[0.238]}\end{array}$ & $\begin{array}{l}8.01^{* * *} \\
{[0.164]}\end{array}$ \\
\hline Right-to-work status & $\begin{array}{l}1.02 \\
{[0.046]}\end{array}$ & $\begin{array}{l}1.15 \\
{[0.116]}\end{array}$ & $\begin{array}{c}1.26^{* * *} \\
{[0.083]}\end{array}$ & $\begin{array}{c}1.01 \\
{[0.054]}\end{array}$ \\
\hline Eligible employees \% & - & $\begin{array}{l}0.75^{* * *} \\
{[0.005]} \\
\end{array}$ & - & - \\
\hline
\end{tabular}

Notes: Robust standard errors, clustered by establishment, are in brackets. $(*),(* *),(* * *)$ indicate

significance at $10 \%, 5 \%, 1 \%$, respectively. Models include 2 -digit SIC industry, state, and year fixed effects.

The following categories are omitted: 1-9 employees and 0-3 years of age. 
TABLE C.9. Odds ratios based on logit model estimates - Manufacturing (The gap between actual versus predicted log. of average wage as explanatory variable)

\begin{tabular}{|c|c|c|c|c|}
\hline \multirow{3}{*}{$\begin{array}{l}\text { Event: } \\
\text { Probability: }\end{array}$} & \multicolumn{2}{|c|}{ Certification: } & \multirow{3}{*}{$\begin{array}{l}\text { Successful } \\
\text { Organizing } \\
O^{o}\left(x_{a}, a\right)\end{array}$} & \multirow{3}{*}{$\begin{array}{l}\text { Union } \\
\text { Status } \\
U^{o}\left(x_{a}, a\right)\end{array}$} \\
\hline & Election & Win & & \\
\hline & $T^{o}\left(x_{a}, a\right)$ & $W^{o}\left(x_{a}, a\right)$ & & \\
\hline Actual - predicted log(average wage) & $\begin{array}{l}1.18^{* * *} \\
{[0.023]}\end{array}$ & $\begin{array}{l}0.76^{* * *} \\
{[0.037]}\end{array}$ & $\begin{array}{l}1.09^{* * *} \\
{[0.033]}\end{array}$ & $\begin{array}{c}0.99 \\
{[0.026]}\end{array}$ \\
\hline 10-19 employees & $\begin{array}{l}6.33^{* * *} \\
{[0.351]}\end{array}$ & $\begin{array}{l}0.59^{* * *} \\
{[0.071]}\end{array}$ & $\begin{array}{l}6.17^{* * *} \\
{[0.485]}\end{array}$ & $\begin{array}{l}3.33^{* * *} \\
{[0.197]}\end{array}$ \\
\hline 20-49 employees & $\begin{array}{l}16.03^{* * *} \\
{[0.833]}\end{array}$ & $\begin{array}{l}0.45^{* * *} \\
{[0.050]}\end{array}$ & $\begin{array}{l}14.32^{* * *} \\
{[1.074]}\end{array}$ & $\begin{array}{l}6.91^{\text {*** }} \\
{[0.457]}\end{array}$ \\
\hline 50-99 employees & $\begin{array}{l}28.38^{* * *} \\
{[1.607]}\end{array}$ & $\begin{array}{l}0.34^{* * *} \\
{[0.040]}\end{array}$ & $\begin{array}{l}21.56^{* * *} \\
{[1.825]}\end{array}$ & $\begin{array}{l}10.81^{* * *} \\
{[0.807]}\end{array}$ \\
\hline 100-249 employees & $\begin{array}{l}36.46^{* * *} \\
{[2.178]}\end{array}$ & $\begin{array}{l}0.25^{* * *} \\
{[0.031]}\end{array}$ & $\begin{array}{l}23.53^{* * *} \\
{[2.151]}\end{array}$ & $\begin{array}{l}12.43^{* * *} \\
{[1.016]}\end{array}$ \\
\hline 250-499 employees & $\begin{array}{l}38.56^{* * *} \\
{[2.778]}\end{array}$ & $\begin{array}{l}0.23^{* * *} \\
{[0.035]}\end{array}$ & $\begin{array}{l}24.06^{* * *} \\
{[2.772]}\end{array}$ & $\begin{array}{l}11.66^{* * *} \\
{[1.167]}\end{array}$ \\
\hline $500+$ employees & $\begin{array}{l}27.53^{* * *} \\
{[2.491]}\end{array}$ & $\begin{array}{l}0.15^{* * *} \\
{[0.032]}\end{array}$ & $\begin{array}{l}15.14^{* * *} \\
{[2.315]}\end{array}$ & $\begin{array}{l}9.42^{* * *} \\
{[1.234]}\end{array}$ \\
\hline $4-6$ years & $\begin{array}{l}0.85^{* * *} \\
{[0.028]}\end{array}$ & $\begin{array}{l}0.85^{* *} \\
{[0.061]}\end{array}$ & $\begin{array}{l}0.78^{* * *} \\
{[0.041]}\end{array}$ & $\begin{array}{l}2.53^{* * *} \\
{[0.066]}\end{array}$ \\
\hline $7-9$ years & $\begin{array}{l}0.77^{* * *} \\
{[0.031]}\end{array}$ & $\begin{array}{l}0.86^{*} \\
{[0.073]}\end{array}$ & $\begin{array}{l}0.73^{* * *} \\
{[0.047]}\end{array}$ & $\begin{array}{l}3.88^{* * *} \\
{[0.145]}\end{array}$ \\
\hline 10-12 years & $\begin{array}{l}0.69^{* * *} \\
{[0.033]}\end{array}$ & $\begin{array}{l}1.01 \\
{[0.102]}\end{array}$ & $\begin{array}{l}0.71^{* * *} \\
{[0.053]}\end{array}$ & $\begin{array}{l}5.37^{* * *} \\
{[0.242]}\end{array}$ \\
\hline 13-15 years & $\begin{array}{l}0.66^{* * *} \\
{[0.038]}\end{array}$ & $\begin{array}{l}0.71^{* * *} \\
{[0.092]}\end{array}$ & $\begin{array}{l}0.56^{* * *} \\
{[0.054]}\end{array}$ & $\begin{array}{l}7.09^{* * *} \\
{[0.372]}\end{array}$ \\
\hline 16-18 years & $\begin{array}{l}0.65^{* * *} \\
{[0.044]}\end{array}$ & $\begin{array}{c}0.91 \\
{[0.135]}\end{array}$ & $\begin{array}{l}0.62^{* * *} \\
{[0.069]}\end{array}$ & $\begin{array}{l}9.13^{* * *} \\
{[0.551]}\end{array}$ \\
\hline 19-21 years & $\begin{array}{l}0.62^{\text {*** }} \\
{[0.053]}\end{array}$ & $\begin{array}{c}0.99 \\
{[0.177]}\end{array}$ & $\begin{array}{l}0.633^{\text {*** }} \\
{[0.084]}\end{array}$ & $\begin{array}{l}11.75^{* * *} \\
{[0.818]}\end{array}$ \\
\hline $22-24$ years & $\begin{array}{l}0.55^{* * *} \\
{[0.064]}\end{array}$ & $\begin{array}{l}0.51^{* * *} \\
{[0.134]}\end{array}$ & $\begin{array}{l}0.39^{* * *} \\
{[0.082]}\end{array}$ & $\begin{array}{l}14.50^{* * *} \\
{[1.177]}\end{array}$ \\
\hline $25+$ years & $\begin{array}{l}0.57^{* * *} \\
{[0.088]}\end{array}$ & $\begin{array}{c}1.19 \\
{[0.389]}\end{array}$ & $\begin{array}{l}0.59^{* *} \\
{[0.133]}\end{array}$ & $\begin{array}{l}18.73^{* * *} \\
{[1.856]}\end{array}$ \\
\hline Multi-unit status & ${ }_{[0.060]}$ & $\begin{array}{l}0.68^{* * *} \\
{[0.041]}\end{array}$ & $\begin{array}{l}1.57^{* * *} \\
{[0.082]}\end{array}$ & $\begin{array}{l}2.37^{* * *} \\
{[0.128]}\end{array}$ \\
\hline Firm union status & ${ }^{2.14^{* * *}}$ & $\begin{array}{l}2.36^{* * *} \\
{[0.183]}\end{array}$ & $\begin{array}{l}3.50^{* * *} \\
{[0.192]}\end{array}$ & ${ }^{2.77^{* * * *}}$ \\
\hline Right-to-work status & $\begin{array}{c}0.88 \\
{[0.119]}\end{array}$ & $\begin{array}{c}0.88 \\
{[0.254]}\end{array}$ & $\begin{array}{c}0.82 \\
{[0.178]}\end{array}$ & $\begin{array}{c}0.98 \\
{[0.112]}\end{array}$ \\
\hline Eligible employees \% & - & $\begin{array}{l}0.77^{\text {*** }} \\
{[0.019]}\end{array}$ & - & - \\
\hline
\end{tabular}

Notes: Robust standard errors, clustered by establishment, are in brackets. $(*),(* *),(* * *)$ indicate

significance at $10 \%, 5 \%, 1 \%$, respectively. Models include 2-digit SIC industry, state, and year fixed effects.

The following categories are omitted: 1-9 employees and 0-3 years of age. 
TABle C.10. Odds ratios based on logit model estimates - All Sectors (Size (employment) and productivity (value of shipments per employee) effects together)

\begin{tabular}{|c|c|c|c|c|}
\hline \multirow{3}{*}{$\begin{array}{l}\text { Event: } \\
\text { Probability: }\end{array}$} & \multicolumn{2}{|c|}{ Certification: } & \multirow{3}{*}{$\begin{array}{l}\text { Successful } \\
\text { Organizing } \\
O^{o}\left(x_{a}, a\right)\end{array}$} & \multirow{3}{*}{$\begin{array}{l}\text { Union } \\
\text { Status } \\
U^{o}\left(x_{a}, a\right)\end{array}$} \\
\hline & Election & Win & & \\
\hline & $T^{o}\left(x_{a}, a\right)$ & $W^{o}\left(x_{a}, a\right)$ & & \\
\hline 10-19 employees & $\begin{array}{l}6.25^{* * *} \\
{[2.210]}\end{array}$ & $\begin{array}{c}1.51 \\
{[0.886]}\end{array}$ & $\begin{array}{l}7.15^{* * *} \\
{[3.341]}\end{array}$ & $\begin{array}{l}4.79^{* * *} \\
{[1.060]}\end{array}$ \\
\hline 20-49 employees & $\begin{array}{l}10.89^{* * *} \\
{[3.471]}\end{array}$ & $\begin{array}{l}0.75 \\
{[0.424]}\end{array}$ & $\begin{array}{l}10.32^{* * *} \\
{[3.436]}\end{array}$ & $\begin{array}{l}9.54^{* * *} \\
{[1.857]}\end{array}$ \\
\hline 50-99 employees & $\begin{array}{l}16.46^{* * *} \\
{[4.725]}\end{array}$ & $\begin{array}{c}0.73 \\
{[0.551]}\end{array}$ & $\begin{array}{l}18.15^{* * *} \\
{[7.011]}\end{array}$ & $\begin{array}{l}13.71^{* * *} \\
{[2.605]}\end{array}$ \\
\hline 100-249 employees & $\begin{array}{l}18.45^{* * *} \\
{[5.793]}\end{array}$ & $\begin{array}{c}0.67 \\
{[0.523]}\end{array}$ & $\begin{array}{l}18.73^{* * *} \\
{[7.845]}\end{array}$ & $\begin{array}{l}14.36^{* * *} \\
{[2.723]}\end{array}$ \\
\hline 250-499 employees & $\begin{array}{l}22.19^{* * *} \\
{[8.946]}\end{array}$ & $\begin{array}{c}0.45 \\
{[0.647]}\end{array}$ & $\begin{array}{l}25.73^{* * *} \\
{[14.463]}\end{array}$ & $\begin{array}{l}23.60^{* * *} \\
{[5.437]}\end{array}$ \\
\hline $500+$ employees & $\begin{array}{l}14.71^{* * *} \\
{[4.296]}\end{array}$ & $\begin{array}{c}0.42 \\
{[0.300]}\end{array}$ & $\begin{array}{l}20.53^{* * *} \\
{[4.677]}\end{array}$ & $\begin{array}{l}27.12^{* * *} \\
{[7.450]}\end{array}$ \\
\hline 11-25 percentile & $\begin{array}{c}0.81 \\
{[0.242]}\end{array}$ & $\begin{array}{l}0.58^{*} \\
{[0.191]}\end{array}$ & $\begin{array}{l}0.52^{* *} \\
{[0.186]}\end{array}$ & $\begin{array}{c}0.83 \\
{[0.218]}\end{array}$ \\
\hline 26-50 percentile & $\begin{array}{c}1.49 \\
{[0.404]}\end{array}$ & $\begin{array}{c}0.54 \\
{[0.211]}\end{array}$ & $\begin{array}{l}1.08 \\
{[0.444]}\end{array}$ & $\begin{array}{l}1.05 \\
{[0.259]}\end{array}$ \\
\hline $51-75$ percentile & $\begin{array}{c}1.46 \\
{[0.459]}\end{array}$ & $\begin{array}{c}0.43 \\
{[0.317]}\end{array}$ & $\begin{array}{c}1.36 \\
{[0.564]}\end{array}$ & $\begin{array}{l}1.30 \\
{[0.319]}\end{array}$ \\
\hline 76-90 percentile & $\begin{array}{c}1.09 \\
{[0.297]}\end{array}$ & $\begin{array}{c}0.35 \\
{[0.511]}\end{array}$ & $\begin{array}{l}1.75^{*} \\
{[0.421]}\end{array}$ & $\begin{array}{l}1.24 \\
{[0.318]}\end{array}$ \\
\hline 91-100 percentile & $\begin{array}{c}1.43 \\
{[0.578]} \\
\end{array}$ & $\begin{array}{c}0.51 \\
{[0.352]} \\
\end{array}$ & $\begin{array}{l}1.77^{*} \\
{[0.417]} \\
\end{array}$ & $\begin{array}{c}1.04 \\
{[0.255]} \\
\end{array}$ \\
\hline
\end{tabular}

Notes: Robust standard errors, clustered by establishment, are in brackets. $\left(^{*}\right),\left({ }^{* *}\right),\left({ }^{* *}\right)$ indicate

significance at $10 \%, 5 \%, 1 \%$, respectively. Models include all other explanatory variables

in Table 1. The following categories are omitted: 1-9 employees, 0-3 years of age, 1-10 percentile. 
TABLE C.11. Odds ratios based on logit model estimates - Manufacturing (Size (employment) and productivity (value of shipments per employee) effects together)

\begin{tabular}{lllll}
\hline \hline \multirow{2}{*}{ Event: } & \multicolumn{2}{c}{ Certification: } & Successful & Union \\
\cline { 2 - 3 } & Election & Win & Organizing & Status \\
Probability: & $T^{o}\left(x_{a}, a\right)$ & $W^{o}\left(x_{a}, a\right)$ & $O^{o}\left(x_{a}, a\right)$ & $U^{o}\left(x_{a}, a\right)$ \\
\hline $10-19$ employees & $7.61^{* * *}$ & 0.74 & $6.94^{* * *}$ & $3.75^{* * *}$ \\
& {$[1.086]$} & {$[0.107]$} & {$[0.278]$} & {$[1.176]$} \\
20-49 employees & $19.49^{* * *}$ & 0.77 & $16.83^{* * *}$ & $5.46^{* * *}$ \\
& {$[2.605]$} & {$[0.073]$} & {$[0.627]$} & {$[1.741]$} \\
$50-99$ employees & $34.38^{* * *}$ & 0.80 & $26.03^{* * *}$ & $9.31^{* * *}$ \\
& {$[4.921]$} & {$[0.049]$} & {$[1.045]$} & {$[3.165]$} \\
$100-249$ employees & $41.66^{* * *}$ & 0.84 & $28.25^{* * *}$ & $9.50^{* * *}$ \\
& {$[6.343]$} & {$[0.038]$} & {$[1.225]$} & {$[3.284]$} \\
$250-499$ employees & $44.22^{* * *}$ & 0.76 & $25.42^{* * *}$ & $7.74^{* * *}$ \\
& {$[7.845]$} & {$[0.045]$} & {$[1.558]$} & {$[2.810]$} \\
$500+$ employees & $37.85^{* * *}$ & 0.80 & $21.51^{* * *}$ & $6.58^{* * *}$ \\
& {$[8.268]$} & {$[0.048]$} & {$[1.284]$} & {$[2.496]$} \\
$11-25$ percentile & $1.38^{* *}$ & $0.56^{* *}$ & 1.07 & $1.38^{*}$ \\
& {$[0.192]$} & {$[0.212]$} & {$[0.220]$} & {$[0.244]$} \\
$26-50$ percentile & $1.98^{* * *}$ & $0.63^{*}$ & $1.58^{* * *}$ & $1.86^{* * *}$ \\
& {$[0.237]$} & {$[0.181]$} & {$[0.238]$} & {$[0.268]$} \\
$51-75$ percentile & $1.90^{* * *}$ & $0.57^{* *}$ & $1.42^{* *}$ & $2.81^{* * *}$ \\
& {$[0.229]$} & {$[0.163]$} & {$[0.290]$} & {$[0.497]$} \\
$76-90$ percentile & $2.30^{* * *}$ & $0.36^{* * *}$ & 1.32 & $2.78^{* * *}$ \\
& {$[0.290]$} & {$[0.183]$} & {$[0.322]$} & {$[0.399]$} \\
91-100 percentile & $2.70^{* * *}$ & $0.41^{* * *}$ & $1.67^{* * *}$ & $2.95^{* * *}$ \\
& {$[0.347]$} & {$[0.231]$} & {$[0.417]$} & {$[0.331]$} \\
\hline \hline
\end{tabular}

Notes: Robust standard errors, clustered by establishment, are in brackets. $(*),(* *),(* * *)$ indicate

significance at $10 \%, 5 \%, 1 \%$, respectively. Models Models include all other explanatory variables

in Table 1. The following categories are omitted: 1-9 employees, 0-3 years of age, 1-10 percentile. 
TABLE C.12. Match rates for selected sectors - 1977-2007

\begin{tabular}{lll}
\hline \hline NLRB Sector Name & Number of Certification Elections & Match Rate \\
\hline Construction & 7,380 & $76.9 \%$ \\
Manufacturing & 34,496 & $77.6 \%$ \\
Retail Trade & 8,809 & $70.0 \%$ \\
Services & 26,123 & $68.8 \%$ \\
Trade, Transportation, and Utilities & 15,616 & $70.3 \%$ \\
Wholesale Trade & 7,246 & $74.7 \%$ \\
All other sectors & 3,394 & $70.1 \%$ \\
Total (All sectors) & 103,064 & $73.1 \%$ \\
\hline \hline
\end{tabular}

